


\section{모태펀드 문화계정 성과지표 개발 연구}

A Study on the Development of Performance Indicators for Cultural Account of Fund of Funds

박찬욱·양지훈 



\section{연구책임}

박찬욱 한국문화관광연구원 연구위원

양지훈 한국문화관광연구원 연구원

\section{공동연구}

이관영 한국문화관광연구원 위촉책임연구원

설원식 숙명여대 경영학 교수

이준호 호서대 경영학 교수

이태호 한국자산운용연구원 원장 

모태펀드 문화계정 성과지표 개발 연구

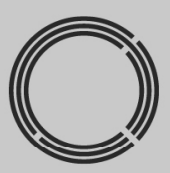

연구개요 



\section{1. 서론}

\section{가. 연구배경}

- 모태펀드 문화계정은 문화산업진흥기금이 폐지된 2006년부터 조성되어 2019 년까지 총 4,022건에 대한 주요 재원역할 수행

- 문화계정은 문화산업의 특수성으로 '수익률' 개선에 구조적인 한계가 있음에 도 불구, 타 계정과의 단순 수익률 비교로 성과측정이 이루어짐

- 모태펀드 문화계정 성과를 나타내는 주된 지표로 ‘수익률’이 사용되고 있고, 타 계정 대비 상대적으로 낮은 수익률로 국회 예산 삭감 등의 부정적 논리 로 활용되고 있음

- 모태펀드 문화계정의 공공적 성격이 반영된 성과지표 개발 필요문제가 지속적 으로 제기됨

- 콘텐츠산업 자체가 고수익 고위험 구조의 투자이기 때문에 물적 기준의 평 가보다는 콘텐츠 자체에 초점을 둔 평가가 필요

- 중진계정 대비 제한적인 투자대상, 기업의 영세성, 높은 투자난이도, 공공적 출자조건(표준계약 의무화, 영화투자비율 제한, 임금체불제작자 투자금지) 등의 구조적 특성 반영이 요구됨

- 정부의 정책방향과 모태펀드의 기본취지에 부합하는 성과지표 개발이 필요

\section{나. 연구목적}

- 모태펀드 문화계정 투자의 성과 및 특수성 분석

- 일반적인 제조업종과 달리 수익예측이 어렵고 고위험 고수익(High risk-High return) 특성 등 타 계정 대비 문화계정만이 지니는 특수성 분석

- 현행 성과지표 체계에 따른 평가의 한계 및 문제점 파악

- 성과측정이 가능하고 체감도가 높은 지표 개발

- 문화계정 펀드운용으로 나타나는 효과를 정량적, 정성적으로 측정할 수 있 는 성과지표 개발

- 문화계정만의 정책 목적성에 부합하는 성과지표 개발 


\section{다. 연구 범위}

- 시간적 범위

- 문화산업진흥기금 폐지 후 모태펀드가 운용되어온 2006년부터 현재 시점 까지 자료 검토

- 공간적 범위

- 국내 콘텐츠 산업 및 투자 환경 전반

- 내용적 범위

- 관련 법률 및 제도 검토

- 모태펀드 운용 현황 자료 검토

- 국내외 유사사례 검토

\section{라. 연구 방법}

- 문헌연구 및 자료 분석

- 정책금융의 흐름 변화 동향지, 모태펀드에 관한 저서, 성과지표 개발 관련 논문, 통계자료 등 모태펀드 문화계정 관련 선행연구 및 보고서 분석

- 국내외 모태펀드 성과지표 사례 분석

- 모태펀드 타계정 등 문화계정 외에 유사정책펀드와 콘텐츠산업 성과 지표 의 사례를 분석하여 시사점을 도출하고, 해당 지표들 중에 문화계정에 활용 할 수 있는 항목 및 지표는 벤치마킹

- 모태펀드 문화계정 전문가 및 업계 관계자 자문회의

- 모태펀드 운영기관(문화계정 담당자, 모태펀드 성과지표 담당자), 문화계정 출자조합 운용사(문화계정 운용 유경험 담당자), 학계 및 연구계 전문가(문 화계정 성과 관련 연구 유경험자)를 대상으로 10 차 자문회의 진행

- 논리모형 활용을 통한 지표 개발

- 논리 모형을 통해 모태펀드 문화계정 구성요소와 그 관계를 각 절차에 따라 시각화하여 사업의 성격과 전 과정을 고려한 효과적인 지표 마련 
- $\mathrm{AHP}$ (계층적 분석법)를 통한 최종 지표 선정 및 가중치 설정

- 지표에 대해서 전문가를 대상으로 $\mathrm{AHP}$ 를 활용하여 최종지표를 선정하고 가중치 적용

\section{2. 모태펀드 문화계정 및 성과평가 현황}

\section{가. 모태펀드 문화계정 현황}

1) 모태펀드의 취지와 정책 금융의 의의

- 모태펀드(Fund of Funds)는 기업이나 프로젝트에 직접투자하지 않고 전문투 자기관을 통해 개별 펀드에 출자하는 간접방식의 금융지원 정책

[그림 1] 모태펀드의 구성 및 구성원

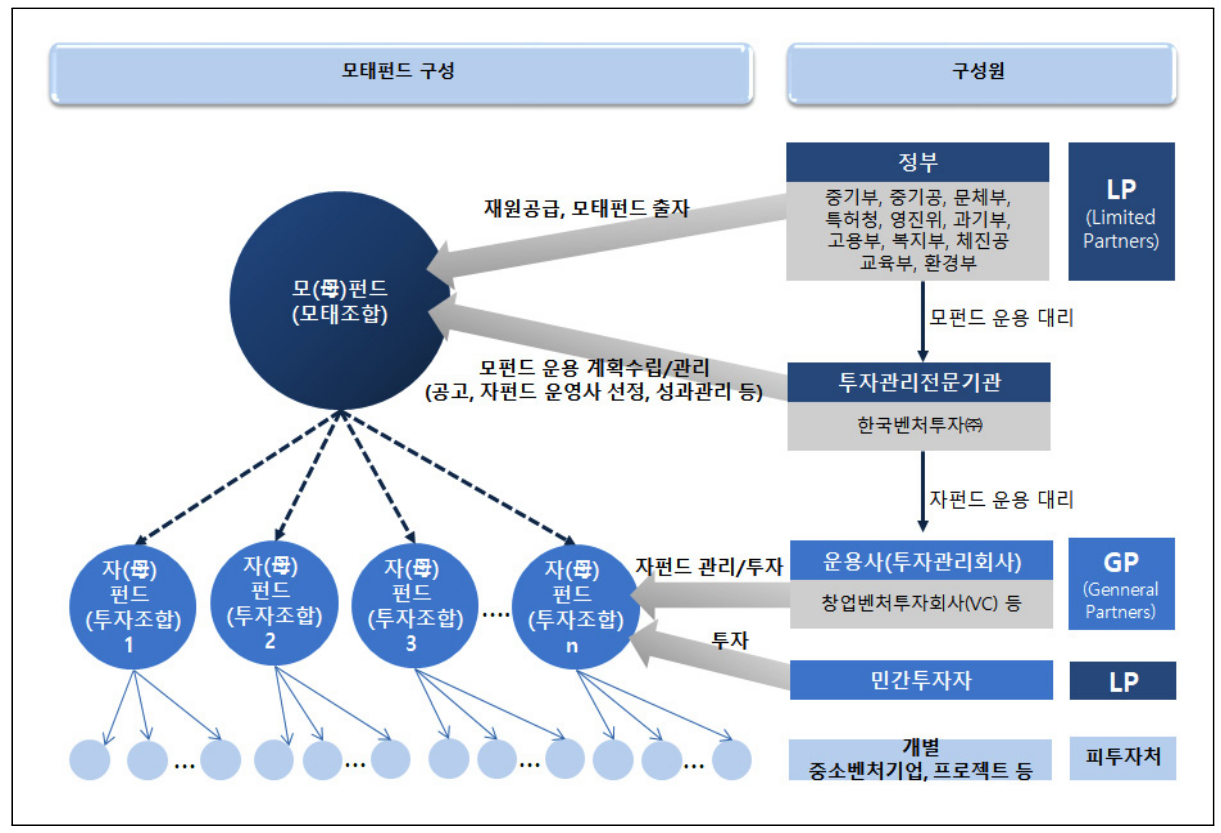

- 정부가 자금을 모아 하나의 모(母)펀드를 결성하고 모펀드를 통해 창업투자 회사(venture capital)가 결성하는 자(子)펀드에 출자하는 방식으로 운영

- 2005년 7월 15일부터 결성이 시작되어 운용기간은 2035년까지 30년 
- 출자자인 정부 각 부처의 영역에 따라 전체 18 개의 계정으로 주 출자분야가 구성되어 있음

- 정책금융으로서의 모태펀드 의의

- 민간 투자 및 벤처캐피탈의 시장실패를 완화하고 정보비대칭 문제를 해소 하여 중소·벤처기업들에게 자금을 원활하게 조달하는 기능

- 초기창업기업이나 위험성이 높은 불확실한 사업아이디어에도 시장에서 자 본이 조달될 수 있도록 도와주는 역할 수행

2) 모태펀드 문화계정 기본 현황

- 모태펀드 문화계정은 모태펀드 운용계획수립, 예산수립, 자펀드 공고, GP선 정, 자펀드 운용계획 수립, 민간투자유치, 투자 등 각 주체별 역할에 따라 체 계적으로 출자가 이루어짐

[그림 2] 모태펀드 문화계정 출자 단계별 과정

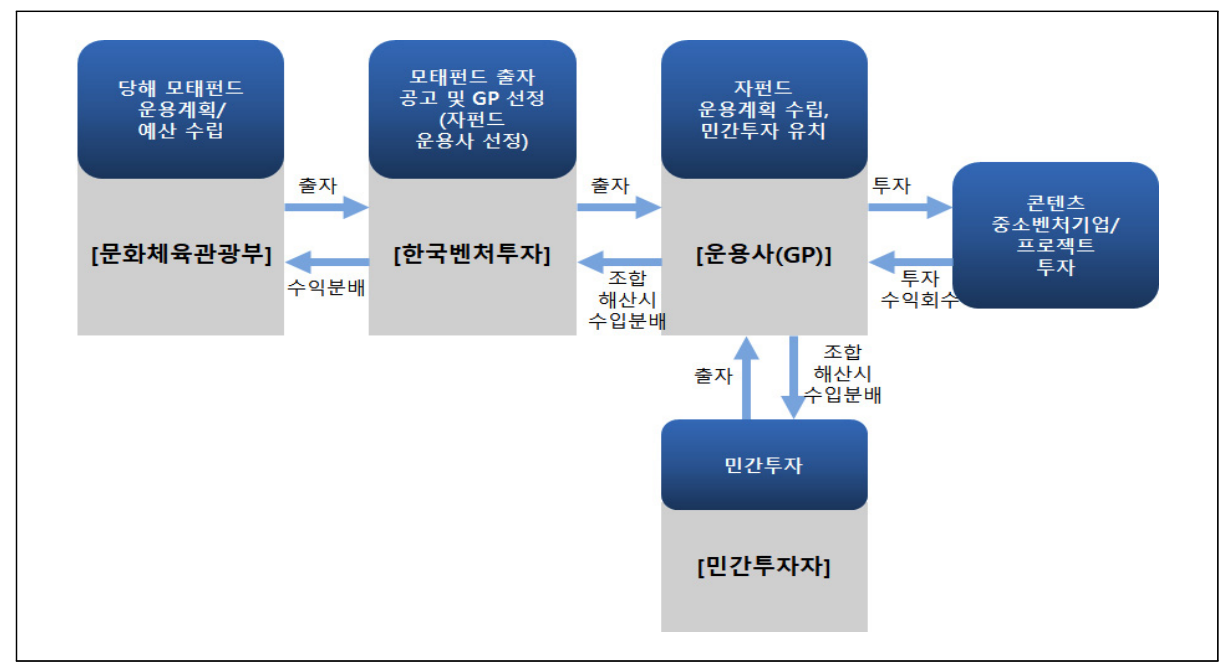

- 최근 8 년간의 출자분야를 분석해보면 장르 출자분야와 정책목표 출자분야로 구분할 수 있음

- 문화계정의 출자분야는 매년 문화체육관광부에서 보통 적게는 4 개, 많게는 6개 정도의 분야를 정책방향에 맞춰 설정하고 한국벤처투자에서는 이에 맞 춰 출자공고를 내 각 분야의 자펀드 운용사를 선정 
〈표 1〉2013년 2020년 출자 분야

\begin{tabular}{|c|c|c|c|c|}
\hline 구분 & 2013년 & 2014년 & 2015년 & 2016년 \\
\hline 장르 & - 애니·캐릭터 & $\begin{array}{l}\text { - 게임 } \\
\text { - 애니·만화·캐릭터 }\end{array}$ & $\begin{array}{l}\text { - 공연·음원 } \\
\text { - 방송 영상 }\end{array}$ & - \\
\hline $\begin{array}{l}\text { 정책 } \\
\text { 목표 }\end{array}$ & $\begin{array}{l}\text { - 재무적출자자 } \\
\text { - 제작초기 } \\
\text { - 글로벌 콘텐츠 }\end{array}$ & $\begin{array}{l}\text { - 재무적출자자 } \\
\text { - 제작초기 } \\
\text { - 글로벌 콘텐츠 }\end{array}$ & $\begin{array}{l}\text { - 기획개발(제작초기) } \\
\text { - 콘텐츠영세기업 } \\
\text { - 재무적출자자 } \\
\text { - 한·중 문화산업공동 } \\
\text { 발전 }\end{array}$ & $\begin{array}{l}\text { - 영세기업\&제작초기 } \\
\text { - 가치평가 연계 } \\
\text { - 융합콘텐츠 } \\
\text { - CG\&애니메이션 } \\
\text { - 한·중 문화산업공동 } \\
\text { 발전 } \\
\text { - 문화-ICT융합 }\end{array}$ \\
\hline 구분 & 2017년 & 2018년 & 2019년 & 2020년 \\
\hline 장르 & - 방송드라마 & $\begin{array}{l}\text { - 게임 } \\
\text { • 애니·캐릭터 } \\
\text { • 출판 }\end{array}$ & $\begin{array}{l}\text { - 공연 } \\
\text { - 게임 }\end{array}$ & $\begin{array}{l}\text { · 게임 } \\
\text { • 애니메이션·캐릭터 }\end{array}$ \\
\hline $\begin{array}{l}\text { 정책 } \\
\text { 목표 }\end{array}$ & $\begin{array}{l}\text { - 콘텐츠기업육성 } \\
\text { - NEW콘텐츠 } \\
\text { - 소액투자전문 }\end{array}$ & $\begin{array}{l}\text { - 일자리 } \\
\text { • 해외개척 }\end{array}$ & $\begin{array}{l}\text { - 청년콘텐츠 } \\
\text { - 지역콘텐츠 } \\
\text { - 콘텐츠 민간제안 }\end{array}$ & $\begin{array}{l}\text { - 해외연계 } \\
\text { - 콘텐츠 IP } \\
\text { - } 5 \mathrm{G} \text { 기술융합 콘텐츠 } \\
\text { - 모험 콘텐츠 }\end{array}$ \\
\hline
\end{tabular}

3) 모태펀드 문화계정 관련 정부의 정책방향과 성과

(1) 문화계정 관련 정부 정책방향

- 자금시장 사각지대(기획개발, 제작초기, 소외장르 등)를 지원하기 위한 정책금 융 신설 및 기존 정책금융 규모 확대1)

- 제작 초기 단계의 프로젝트 등 그간 투자가 미진했던 분야에 집중 투자하기 위해 '콘텐츠 모험투자 자금'을 대규모로 조성, 콘텐츠 모험분야 투자 확대

- 모태펀드 문화계정 내에 기획개발·제작초기·소외장르(애니메이션, 출판, 음 원 등)에 집중 투자하는 펀드로 기존 투자 사각지대 해소 목적

- 모태펀드 등 간접지원 중심으로 지원체계 전환

- 그간 제작지원 사업 등 직접지원 중심으로 이루어진 지원사업 체계를 정부 가 간접지원 중심으로 전환을 시도함에 따라 모태펀드의 규모와 대상이 더 욱 확대될 전망

1) 콘텐츠산업 3대 혁신 전략, 관계부처 합동(2019) 
(2) 문화계정의 그간 성과

- 모태펀드 문화계정은 2006년부터 조성되어 2019년까지 총 4,022건에 2조 3,471억 원 투자 진행하는 등 콘텐츠 투자 기반 확보

〈표 2〉 모태펀드 문화계정 현황('19년 기준, 단위: 억원)

\begin{tabular}{c|c|c|c|c|c|c|c|c|c|c|c}
\hline 구분 & '10 & '11 & '12 & '13 & '14 & '15 & '16 & '17 & '18 & '19 & 합계 \\
\hline 조성액 & 5,918 & 2,410 & 200 & 1,190 & 355 & 2,989 & 2,231 & 1,221 & 2,036 & 2,648 & 21,198 \\
\hline $\begin{array}{c}\text { 투자 } \\
\text { 금액 }\end{array}$ & 4,379 & 2,414 & 2,396 & 2,215 & 2,151 & 2,059 & 2,023 & 1,801 & 1,658 & 2,375 & 23,471 \\
\hline $\begin{array}{c}\text { 투자 } \\
\text { 건수 }\end{array}$ & 864 & 437 & 419 & 414 & 367 & 306 & 330 & 282 & 283 & 320 & 4,022 \\
\hline
\end{tabular}

- 도입기를 넘어 본격적으로 성장과 투자가 적극적으로 필요한 시점이었던 일부 콘텐츠산업의 “산업고도화”를 이끌면서 마중물 역할을 수행

- 기반이 약하여 실패확률이 높아 투자되지 않은 분야의 투자를 활성화시켜, 근본적으로 산업 성장의 기회를 제공하고 고도화하는데 기여

- 운용사의 관리를 통해 전문성과 투명성을 제고하고, 투자 시 규약으로 제도 정착에 기여하여 산업으로의 면모를 갖추도록 이끎

- 초기 기업투자를 통해 유니콘 콘텐츠 기업 창출

- (주)블루홀은 지난 2009년 초기 자금이 바닥나 추가 투자 유치가 시급한 상 황에서 모태펀드의 출자를 받아 2011년 1월 다중접속역할수행게임 (MMORPG) '테라’를 개발하여 게임시장에 성공적으로 안착

4) 모태펀드 문화계정의 한계

- 타 모태펀드 계정에 비해 낮은 수익률

- 수익을 내지 못한다는 것은 결과적으로 투자재원의 감소를 가져오도록 하 고 장기적으로는 모태펀드 규모 자체의 축소를 초래 
- 영세기업의 투자유치가 어려운 콘텐츠산업의 구조적 한계

- 콘텐츠산업 구성원의 대다수가 영세기업임에도 불구 물적 기준을 중심으로 투자 평가가 이루어져 투자유치가 난이

- 결과물의 무형 특성으로 인한 정보의 비대칭성 존재

- 콘텐츠산업은 무형의 결과물들이 대부분이기 때문에 자금 수요자와 공급자 간 정보 비대칭성이 매우 크게 나타나 자금조달이 매우 어려움

- 전략적 투자(SI)와 같은 시장교란으로 인한 투자 효율성 문제

- 정책투자의 규정에서 금지 사항인 이해관계자 연관 투자가 관행상으로는 암묵적으로 진행되고 있음

- 특정 장르 투자 편중성에 따른 공적 목표 달성에 미흡

- 2019년 8월 말을 기준으로 문화계정의 총 누적투자금액(문체부 출자자금+ 민간자금)은 2조 363 억원인데, 투자자금 중 $48.2 \%$ 가 영화

- 콘텐츠 산업만의 특성을 미반영

- 문화계정은 타계정과 달리, 투자를 통한 '문화산업 활성화'라는 문화체육관 광부의 정책 취지가 부합해야함에도 다소 중소벤처기업 활성화를 위한 모 태펀드의 기본취지에 정책방향이 쏠려있음

\section{나. 모태펀드 문화계정 성과평가 현황}

- 본 연구에서는 문화계정 특화지표가 있었던 2015년 성과지표와 가장 최근에 진행되었던 2019년 모태펀드 성과지표를 대상으로 분석을 진행

1) 2015 년 모태펀드 문화계정 성과지표

- 6 개 전략목표, 16 개 성과목표에 따른 개별 성과지표를 37 개 구성 
〈표 3〉2015년 모태펀드 성과 지표

\begin{tabular}{|c|c|}
\hline 전략목표 & 성과목표 \\
\hline \multirow{4}{*}{ 중소·벤처기업성장 } & 투자기업성장성 \\
\hline & 투자기업 안정성 \\
\hline & 투자기업 수익성 \\
\hline & 투자기업 고용증대 \\
\hline \multirow{3}{*}{$\begin{array}{c}\text { 벤처캐피탈산업의 } \\
\text { 성장 및 시장 선진화 }\end{array}$} & 벤처캐피탈산업 활성화 및 선진화 지원 \\
\hline & 벤처캐피탈산업 글로벌화 지원 \\
\hline & 모태펀드 출자 자펀드 평균 규모 증가 \\
\hline \multirow{3}{*}{ 중점정책과제 달성 } & 시장실패 영역 투자 확대 \\
\hline & 특허계정 정책 목표 \\
\hline & 문화계정 정책 목표 \\
\hline \multirow{2}{*}{ 자펀드 운용의 효율성 } & 사후관리 및 운용프로세스 개선 \\
\hline & 운용의 효율성 달성 \\
\hline 모태펀드의 수익성 추구 & 모태펀드 수익성 \\
\hline \multirow{3}{*}{ 자펀드 선정의 공정성과 합리성 } & 심사기준 합리성, 객관성 달성 \\
\hline & 자펀드 수시 출자 확대 \\
\hline & 자펀드 선정과정의 투명성과 공정성 달성 \\
\hline
\end{tabular}

- 문화계정의 특수성을 반영하여 '문화계정 정책목표'라는 성과에 따른 4 개의 문화계정 특수지표를 구성

- 문화계정 투자를 통한 산업 육성은 영화산업 매출액 증가율과 국내영화 매 출액 증가율을 파악하여 평가

- 다만, 문화계정 정책목표 지표의 대부분이 해당 산업전체에 해당되어 지나친 일반화라는 점과 영화산업에만 특화된 지표라는 한계가 있었음

- 전체적으로 과정(process)-산출(output)-결과(outcome)의 체계성을 갖추어 있었고, 문화계정의 특성을 반영한 지표가 존재했다는 의의가 있음

2) 2019년 모태펀드 성과지표

- 5 개 성과목표에 따른 개별 성과지표를 12 개 구성 
〈표 4〉2019년 모태펀드 성과 지표

\begin{tabular}{|c|c|}
\hline 성과목표 & 성과지표 \\
\hline \multirow{3}{*}{$\begin{array}{c}\text { 모태펀드 } \\
\text { 투자금액 확대 }\end{array}$} & 모태출자펀드 연간 투자 금액 \\
\hline & 모태출자펀드 투자기업에 대한 해외 후속투자유치 금액 \\
\hline & 모태출자펀드 투자진척률 \\
\hline $\begin{array}{c}\text { 집중육성분야 모태출자펀드 } \\
\text { 투자금액 확대 }\end{array}$ & 모태출자펀드 주목적 투자 달성 비율 \\
\hline \multirow{3}{*}{$\begin{array}{l}\text { 민간 LP 참여 } \\
\text { 확대 }\end{array}$} & 회수시장 활성화: M\&A 건 수 및 IPO 건 수 \\
\hline & 시장건전성 제고: 모태출자펀드 규약 및 법령위반 건 수 \\
\hline & 민간 자금 출자 비중 \\
\hline \multirow{3}{*}{$\begin{array}{c}\text { 모태출자펀드 } \\
\text { 투자기업 } \\
\text { 성과 관리 }\end{array}$} & 피투자기업 일자리 증가 \\
\hline & 피투자기업 매출액 증가 \\
\hline & 모태출자펀드 투자기업 기업가치 증가 \\
\hline \multirow{2}{*}{$\begin{array}{c}\text { 모태펀드 } \\
\text { 수익률 제고 }\end{array}$} & 모태출자펀드 평가 수익배수(일반분야) \\
\hline & 모태출자펀드 평가 수익배수(집중육성분야) \\
\hline
\end{tabular}

- 각 부처의 정책적 방향과 분야에 따라 다르게 구성되어 있는 18 개의 모태펀드 계정이 거의 동일한 기준으로 평가되고 있는 한계가 존재

- 각 계정의 특성을 담을 수 있는 항목은 모태출자펀드 주목적 투자 달성 비 율 밖에 없으며, 특히 문화계정의 특성을 나타낼 수 있는 성과지표는 구성 되어 있지 않음

- 논리적인 흐름이나 성과의 특성에 따른 전략목표 체계설정이 아니라 각 전략 목표들이 독립적으로 모태펀드의 양적 성과만을 중심으로 이어져 궁극적인 목 표 수립정도를 파악하기 어려움

- 계획-실행-성과나, 투입-과정-결과와 같은 일반적인 논리흐름의 체계로 살 펴보면 거의 성과와 결과 지표 중심이고 일부 과정이나 계획에 대한 부분의 고려는 상대적으로 부족

- 펀드에서 일반적으로 활용되는 계량적인 지표 중심으로 이루어져 모태펀드 만의 정책적이고 각 계정의 이슈 관련 심층적인 내용이 반영되기 어려움 


\section{3. 사례 분석 및 전문가 자문회의}

\section{가. 사례 분석}

- 모태펀드 타계정 등 문화계정 외에 유사정책펀드와 콘텐츠산업 성과 지표의 사례를 분석하여 시사점을 도출하고, 해당 지표들 중에 문화계정에 활용할 수 있는 항목 및 지표는 벤치마킹

〈표 5〉사례분석 대상 및 결과

\begin{tabular}{|c|c|c|}
\hline 분류 & 사례분석 대상 & 분석 내용 및 시사점 \\
\hline \multirow{3}{*}{$\begin{array}{l}\text { 유사 } \\
\text { 정책펀드 } \\
\text { 성과 지표 }\end{array}$} & 농식품모태펀드 성과 지표 & $\begin{array}{l}\text { - 성과지표를 사업운용 시기(단기, 중기, 장기)별로 구분하여 } \\
\text { 각 시기에 맞는 성과지표를 적용 } \\
\text { - 비계량 평가는 계획, 실행, 성과 관점에서 평가하여 논리적인 } \\
\text { 구성을 갖춤 }\end{array}$ \\
\hline & 모태펀드 중진계정 성과 지표 & $\begin{array}{l}\text { - 중소벤처기업부의 주된 정책방향인 중소벤처기업의 활성화의 } \\
\text { 취지에 맞춰서 ‘창업초기기업 투자규모 확대'라는 특화지표 } \\
\text { 가 추가 } \\
\text { - 집중육성분야 모태출자펀드 투자금액 확대 성과목표에 대해 } \\
\text { 서는 타계정의 모태출자펀드 주목적 투자달성만 지표로 설정 } \\
\text { 한 것과 달리 구체적으로 집중육성분야에 대한 세부 지표들 } \\
\text { 을 마련 }\end{array}$ \\
\hline & 성장사다리펀드 성과 지표 & $\begin{array}{l}\text { - 성과목표에서는 계회(운용계확출자계획의 충실성 등), 실행 } \\
\text { (선정절차 및 기준의 공정성 등), 성과(목표수익률), 효과(투 } \\
\text { 자선순환유도, 피투자기업 성장 등)에 관련한 지표들이 체계 } \\
\text { 적으로 구성 } \\
\text { - 측정 가능한 계량지표와 노력도와 같은 비계량 성과지표를 } \\
\text { 결합하여 상호 보완 }\end{array}$ \\
\hline \multirow[t]{2}{*}{$\begin{array}{l}\text { 콘텐츠 } \\
\text { 산업 } \\
\text { 성과 지표 }\end{array}$} & 지역콘텐츠산업 경쟁력 지표 & $\begin{array}{l}\text { - 콘텐츠산업의 특수성을 고려하여 콘텐츠산업의 산업 구조 요 } \\
\text { 소와 행위 요소, 그로 인해 나타난 성과 요소를 종합적으로 } \\
\text { 측정하는 지표를 개발 } \\
\text { - 지표를 } 3 \text { 가지 핵심영역(자원 경쟁력, 활동 경쟁력, 성과 경쟁 } \\
\text { 력), } 4 \text { 가지 핵심 요소(구조, 행위, 성과, 지역이 보유한 자 } \\
\text { 원), } 5 \text { 가지 핵심 지표(자원 지표, 성과 지표, 산업 지표, 환경 } \\
\text { 지표, 정책 지표)로 체계성을 갖춤 }\end{array}$ \\
\hline & 콘텐츠 경쟁력 지표 & $\begin{array}{c}\text { •콘텐츠 경쟁력 평가 방안 연구의 평가 방안 개발은 콘텐츠 산 } \\
\text { 업의 가치사슬 구조(기획, 제작, 유통)를 기본으로 각 과젱에 } \\
\text { 대한 세부 평가항목을 제시하는 방식의 논리구조를 취함 }\end{array}$ \\
\hline
\end{tabular}




\section{나. 전문가 의견 조사}

- 실질적인 지표 개발을 위해 전문가 및 업계 관계자 자문회의를 진행하여 모 태펀드 문화계정의 현황과 문제점을 파악하고 지표개선 방안을 마련

- 기간: 2020년 5월 1일 2020년 7월 30일

- 자문회의 차수: 8차에 걸쳐서 전문가 자문회의 진행

- 대상: 모태펀드 운영기관(문화계정 담당자, 모태펀드 성과지표 담당자), 문 화계정 출자조합 운용사(문화계정 운용 유경험 담당자), 학계 및 연구계 전 문가(문화계정 성과지표 개발 유경험자, 성과평가 유경험자, 문화계정 관련 연구 유경험자)

- 방법: 구조화된 질문지 또는 회의 안건 제시를 통한 토론 진행, 온라인 원격 회의와 현장회의 병행

〈표 6〉전문가 의견 조사 결과

\begin{tabular}{|c|c|}
\hline 주요 의견 & 세부 내용 \\
\hline $\begin{array}{c}\text { 프로젝트 투자(PF)가 주도하는 } \\
\text { 특성 고려 필요 }\end{array}$ & $\begin{array}{l}\text { - 최근 들어서야 기업투자가 늘어나고는 있지만 문화계정은 타계정과 다르 } \\
\text { 게 프로젝트 중심(Project Finance)으로 투자가 이루어지는 경향 존재 } \\
\text { - 모태펀드 문화계정의 투자 대상의 과반수이상이 프로젝트 투자임에도 불 } \\
\text { 구하고 관련 지표가 대부분 기업 중심으로 이루어짐 }\end{array}$ \\
\hline $\begin{array}{c}\text { 콘텐츠산업 분야 간 } \\
\text { 큰 격차를 극복할 수 있는 } \\
\text { 지표 구성 필요 }\end{array}$ & $\begin{array}{l}\text { - 문화계정의 영역이 워낙 넓고 복잡하여 산업의 수명주기 상 성장기를 거쳐 } \\
\text { 성숙기를 향하고 있는 영역과 도입기나 초기 성장기 단계의 취약한 시장 } \\
\text { 간의 간극이 매우 커 일괄적으로 평가하기 어려움 존재 } \\
\text { - 또한 투자의 관점에서의 장르와 산업 발전 관점에서의 장르는 서로 달라서 } \\
\text { 단순히 콘텐츠산업 장르 구분을 기준으로 성숙분야와 미성숙 분야를 나누 } \\
\text { 는 것은 무의미 }\end{array}$ \\
\hline $\begin{array}{c}\text { 성과지표 간 유기적으로 } \\
\text { 연결될 수 있도록 체계성 } \\
\text { 강화 필요 }\end{array}$ & $\begin{array}{l}\text { - 현재 } 18 \text { 개의 모태펀드 각 계정에 일괄적으로 적용하고 있는 성과지표는 } \\
\text { 각 성과목표들이 파편적으로 이루어져 연결성이 떨어짐 } \\
\text { - 성과목표에 대해 여러 개의 성과지표들이 구성되어 상호보완적으로 평가 } \\
\text { 체계를 구성하고는 있지만, 대부분 모태펀드 일반에 대한 계량적인 평가 } \\
\text { 위주로 이루어짐 }\end{array}$ \\
\hline $\begin{array}{c}\text { 문화계정의 } \\
\text { 높은 정책기여도 고려 }\end{array}$ & $\begin{array}{l}\text { - 문화계정의 가장 큰 특징 중에 또 하나는 제약이나 의무조항들이 형성하는 } \\
\text { 허들이 너무 높다는 것이며, 이는 그만큼 문화콘텐츠 정책에 기여하는 바 } \\
\text { 가 높다는 것을 반증 } \\
\text { - 문화계정 운용 시, 대다수의 투자대상 프로젝트나 기업들은 영세하거나 초 } \\
\text { 기사업자들이 많기 때문에 운용사에서는 운용관리과정에서 일정부분 엑셀 } \\
\text { 러레이터 역할을 담당하는 부분도 있음 }\end{array}$ \\
\hline
\end{tabular}




\section{4. 모태펀드 문화계정 성과지표 개발}

\section{가. 성과지표 개선 방향}

- 앞서 진행한 모태펀드 문화계정 현황분석, 기존 평가지표 분석, 사례분석, 전 문가 자문회의·인터뷰 등의 결과물들을 종합·정리하여 모태펀드 문화계정의 지표개발 방향과 방안들을 도출

[그림 3] 모태펀드 문화계정 성과지표 개발 방향 및 방안 도출 과정

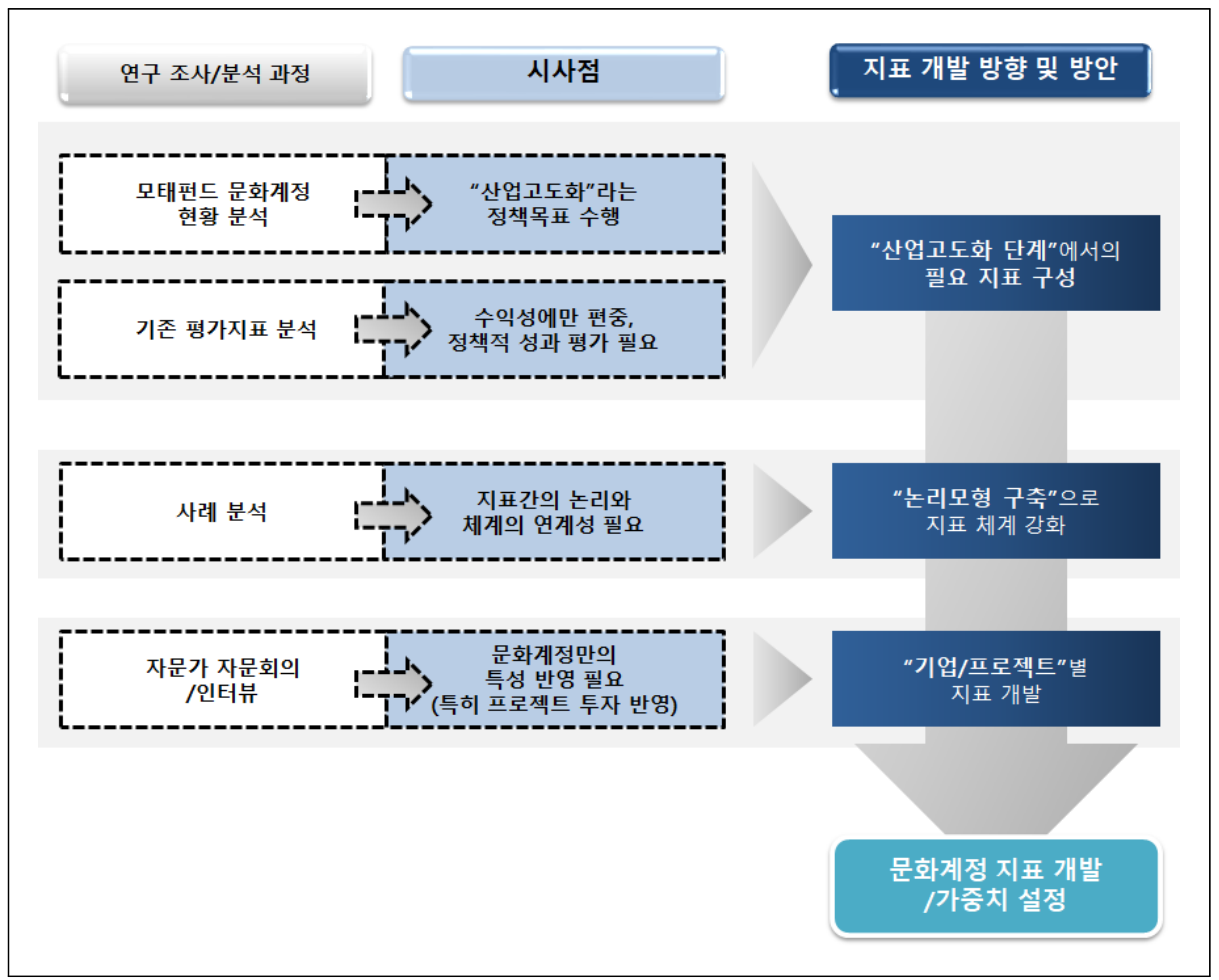

- 영화산업에서 나타난 모태펀드 “산업 고도화” 역할에 주목

- 영화산업의 발전과정에서 모태펀드는 산업 고도화에 상당부분 기여했으며, 향후 민간투자가 활성화되어 지속적으로 성장하게 된다면 국가의 핵심 콘 텐츠산업으로 발전할 가능성이 있음

- 모태펀드의 영화산업에서 축적된 경험을 바탕으로 위기에서 발전 임계점까 지 버티게 해줄 수 있는 동력을 마련하고 산업성장의 기반을 구축하여 궁극 적으로 산업발전을 이룰 수 있는 성공모델을 더 확장할 필요가 있음 


\section{나. 문화계정 성과지표 개발}

- 산업단계에 따른 필요요소별 성과지표 파악을 통해 도출하였던 성과지표 후보 군 리스트를 논리모형 모델에 도입하고 연구진 및 전문가가 참석한 자문회의 를 통하여 최종 성과지표를 선정

[그림 4] 최종지표 도출 과정

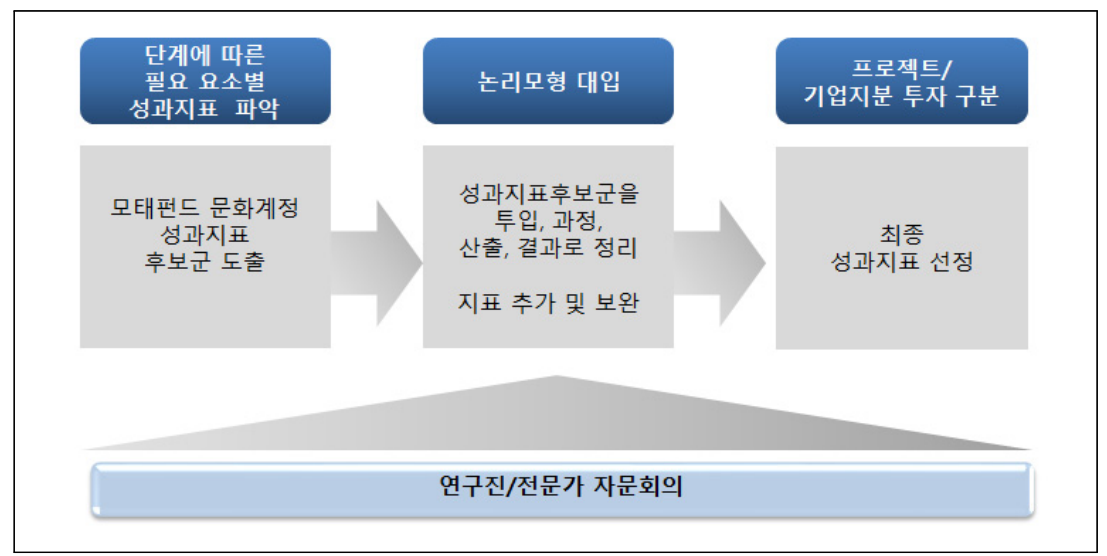

1) 성과지표 후보 도출

- 모태펀드 문화계정은 콘텐츠산업을 위한 정책금융 중에서도 성장단계에 적합 한 자금조달 수단이며 산업고도화의 기능이 강조됨

- 이러한 관점을 Porter의 경쟁력 발전단계에 대입하면, 모태펀드는 산업발전단 계에서 '투자주도단계 또는 혁신주도단계 초반'에 적합한 정책지원

[그림 5] 산업발전 단계별 필요 요소와 모태펀드 투입시기

\begin{tabular}{|c|c|c|c|c|}
\hline $\begin{array}{c}\text { 구분 } \\
\text { (수명주기) }\end{array}$ & $\begin{array}{l}\text { 요소주도단계 } \\
\text { (도입기) }\end{array}$ & $\begin{array}{l}\text { 투자주도단계 } \\
\text { (성장기) }\end{array}$ & $\begin{array}{c}\text { 혁신주도단계 } \\
\text { (선노기) }\end{array}$ & $\begin{array}{c}\text { 부(富)주도단계 } \\
\text { (쇠퇴기) }\end{array}$ \\
\hline 요소조건 & $\begin{array}{l}\text { 생산요소 } \\
\text { (노동, } \\
\text { 자원 등) }\end{array}$ & $\begin{array}{l}\text { 생산요소 및 } \\
\text { 고급요소 } \\
\text { (기술 등) }\end{array}$ & $\begin{array}{c}\text { 고급여소 및 } \\
\text { 기본요소의 } \\
\text { 불리점 }\end{array}$ & $\begin{array}{l}\text { 전통적 } \\
\text { 요소의 } \\
\text { 유리점 }\end{array}$ \\
\hline 수요조건 & - & $\begin{array}{c}\text { 국내 } \\
\text { 수요의 } \\
\text { 확대 }\end{array}$ & $\begin{array}{c}\text { 수요의 질적 } \\
\text { 향쌍 } \\
\text { 해외수요확대 }\end{array}$ & $\begin{array}{l}\text { 수요의 } \\
\text { 질적,양적 } \\
\text { 하락 }\end{array}$ \\
\hline $\begin{array}{l}\text { 기업전략 구조 } \\
\text { 및 경쟁조건 }\end{array}$ & - & $\begin{array}{c}\text { 투자동기부여 } \\
\text { 및 } \\
\text { 국내경쟁 심화 }\end{array}$ & $\begin{array}{c}\text { 글로벌한 전략 } \\
\text { 및 } \\
\text { 해외진출 확대 }\end{array}$ & $\begin{array}{c}\text { 투자동기 } \\
\text { 상실, } \\
\text { 경쟁 쇠퇴 }\end{array}$ \\
\hline $\begin{array}{l}\text { 지원 및 } \\
\text { 외부조건 }\end{array}$ & - & - & $\begin{array}{l}\text { 기반무축 } \\
\text { 완!監 }\end{array}$ & $\begin{array}{l}\text { 기반 } \\
\text { 취약 }\end{array}$ \\
\hline
\end{tabular}


- 산업 고도화 단계라고 할 수 있는 투자주도단계와 초기 혁신주도단계에서 갖추어 야할 필수요소들을 콘텐츠산업에 적용하여 각 필요요소들에 맞는 지표후보 도출 〈표 7〉 성과평가 지표 후보군과 그 도출 과정

\begin{tabular}{|c|c|c|c|c|}
\hline $\begin{array}{l}\text { 필요 } \\
\text { 요소 }\end{array}$ & 구성요소 & 콘텐츠산업 적용 내용 & & $\begin{array}{l}\text { 개발 성과지표 } \\
\text { 후보군 }\end{array}$ \\
\hline \multirow{4}{*}{$\begin{array}{l}\text { 요소 } \\
\text { 조건 } \\
\text { (부존/ } \\
\text { 창출) }\end{array}$} & 인적자본 & $\begin{array}{l}\text { - 창의적 전문인력 부존(고급인력과 기초인력) } \\
\text { • 콘텐츠산업 인력의 질적 수준(기능, 작업능력 등) }\end{array}$ & $\Rightarrow$ & $\begin{array}{l}\text { - 전문·고급 인력 창출 } \\
\text { - 고용증가 } \\
\text { - 인력 질적수준 }\end{array}$ \\
\hline & 자본 & $\begin{array}{l}\text { - 자본조달에 대한 상대적 접근성(투자자본창출) } \\
\text { - 업계의 접근이 용이한 자본조달방식의 존재 여부 } \\
\text { - 자본의 부존(제외) }\end{array}$ & $\Rightarrow$ & $\begin{array}{l}\text { - 자본 창출 } \\
\text { - 자금조달 용이성 } \\
\text { - 투자유치 성과 } \\
\text { - 후속투자 유치 } \\
\text { - 민간자금유치노력 }\end{array}$ \\
\hline & 요소의 창출 & $\begin{array}{l}\text { • 국가적인 차별화된 전문인력 양성시스템 } \\
\text { - 공동제작시설의 질적, 양적 수준 } \\
\text { - 혁신에 의한 요소창출(혁신적인 제작공정의 도입 등) } \\
\text { - 종업원의 사내교육, 훈련시스템 }\end{array}$ & $\Rightarrow$ & $\begin{array}{l}\text { - 컨설팅 및 관리 } \\
\text { - 인력 양성/훈련 } \\
\text { - 제작 질 제고 기여 } \\
\text { - 제작 양 확대 기여 } \\
\text { - 혁신성 }\end{array}$ \\
\hline & $\begin{array}{l}\text { 기술: } \\
\text { 저작권 }\end{array}$ & - 저작권, 특허권 등 산업재산권의 보유 수준 & & $\begin{array}{l}\text { - 저작권, 특허 창출 } \\
\text { - IP수익창출(OSMU) }\end{array}$ \\
\hline \multirow{3}{*}{$\begin{array}{l}\text { 수요 } \\
\text { 조건 }\end{array}$} & 국내수요 & $\begin{array}{l}\text { - 국내시장 공급자 수 대비 상대적인 시장규모 } \\
\text { - 시장 증가율 }\end{array}$ & & $\begin{array}{l}\text { - 투자수익성 } \\
\text { - 산업성장/육성 기여 } \\
\text { - 투자기업성장성 } \\
\text { - 투자기업안전성 }\end{array}$ \\
\hline & 수요의 구성 & $\begin{array}{l}\text { - 콘텐츠 수요의 세분화(소비자 선호의 다양성) } \\
\text { - 콘텐츠에 대한 소비자 욕구의 다양성 } \\
\text { - 소비자의 콘텐츠에 대한 평가, 개선의견 제시 등의 } \\
\text { 참여도, 적극성 }\end{array}$ & $\Rightarrow$ & $\begin{array}{l}\text { - 목적투자집행률 } \\
\text { - 고객/소비자 만족도 } \\
\text { - 다양성 확대 } \\
\text { - 언론노출 정도 }\end{array}$ \\
\hline & $\begin{array}{l}\text { 수요의 } \\
\text { 국제화 }\end{array}$ & - 국산콘텐츠에 대한 해외수요의 강도 & & $\begin{array}{l}\text { - 해외자본유치노력 } \\
\text { - 해외자본비율 } \\
\text { - 수출 } \\
\text { - 수상실적 } \\
\text { - 글로벌 영향력 확대 } \\
\text { - 국가브랜드제고 }\end{array}$ \\
\hline \multirow{3}{*}{$\begin{array}{l}\text { 기업 } \\
\text { 전략 } \\
\text { /경쟁 } \\
\text { 조건 }\end{array}$} & 기업전략 & $\begin{array}{l}\text { - 경쟁강도 } \\
\text { - 경쟁전략 및 경영방식의 우수성 } \\
\text { • 업계 종사자들의 열의와 경쟁력 }\end{array}$ & $\Rightarrow$ & $\begin{array}{l}\text { - 생존율 } \\
\text { - 시장건전성 } \\
\text { - 신용등급변화 }\end{array}$ \\
\hline & $\begin{array}{l}\text { 시장구조 } \\
\text { (산업의 } \\
\text { 집중도) } \\
\end{array}$ & $\begin{array}{l}\text { - 장르별 산업집중도(전체 업체 중 대형기업의 역할 } \\
\text { 및 비중) } \\
\text { - 선도적 기업의 존재 여부 }\end{array}$ & $\Rightarrow$ & $\begin{array}{l}\text { - 산업집중도 } \\
\text { - 대형기업 투자 정도 } \\
\text { - 배급사 기여 }\end{array}$ \\
\hline & 경쟁 & $\begin{array}{l}\text { - 잠재적 시장진입의 용이성 } \\
\text { - 대체재의 존재(제외) } \\
\text { - 시장개방도, 외국콘텐츠와의 경쟁 수준 }\end{array}$ & $\Rightarrow$ & $\begin{array}{l}\text { - 투자처풀 적절성 } \\
\text { - 개방성(투명성) } \\
\text { - 투자기업수 }\end{array}$ \\
\hline
\end{tabular}




\section{2) 논리모형 대입 및 프로젝트/기업 투자 구분}

- 투입(Input), 과정(Process), 산출(Output), 결과(Outcome) 4가지 요소로 구성된 논리모형에 앞서 도출한 성과지표후보군의 리스트들을 대입하고, 전문 가 및 연구진 회의를 통해 최종 성과지표를 선정

\section{[그림 6] 논리모형 구성}

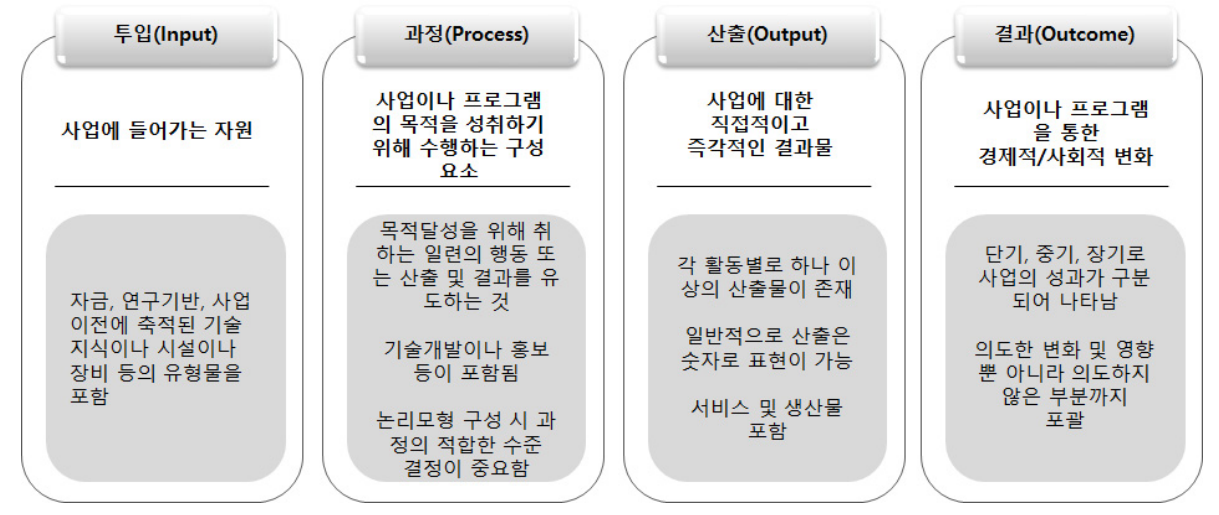

- 그 결과, 최종 도출한 성과지표는 논리모형 4 개의 분류에 따라 프로젝트 투자 에서는 16 개, 기업 투자에서는 17 개로 각각 구성됨

- 프로젝트 투자와 기업 지분투자의 기본항목들은 공통으로 들어가되 각 투자 의 특성에 따라 필요한 지표들을 추가로 개발

〈표 8〉 모태펀드 문화계정 최종 성과지표(안)

\begin{tabular}{|c|c|c|c|c|}
\hline \multirow{2}{*}{ 구분 } & \multicolumn{2}{|c|}{ Enablers } & \multicolumn{2}{|c|}{ Results } \\
\hline & 투입(Input) & 과정(Process) & 산출(Output) & 결과(Outcome) \\
\hline 프로젝트 & $\begin{array}{l}\text { (1) 목적투자 정도 } \\
\text { (2) 민간자본 유치 노력 } \\
\text { (3) 투자 프로젝트 규모 } \\
\text { (수) } \\
\text { (4) 해외자본 유치노력 }\end{array}$ & $\begin{array}{l}\text { (1) 공모 투명성(개방성) } \\
\text { (2) 프로젝트 지원 및 } \\
\text { 관리 } \\
\text { (3) 과정 공정성 } \\
\text { (4) 준법.건전성 } \\
\text { (5) 지원의 시의성 }\end{array}$ & $\begin{array}{l}\text { (1) 수익성 } \\
\text { (2) 피투자처만족도 } \\
\text { (3) 해외매출 } \\
\text { (4) 화제성 }\end{array}$ & $\begin{array}{l}\text { (1) 고용증가 }(\mathrm{m} / \mathrm{h}) \\
\text { (2) 산업육성기여 } \\
\text { (3) IP수익창출(OSMU) } \\
\text { (4) 산업분산도 } \\
\text { (5) 국가브랜드제고 }\end{array}$ \\
\hline 기업 & $\begin{array}{l}\text { (1) 목적투자 정도 } \\
\text { (2) 민간자본 유치 노력 } \\
\text { (3) 투자 기업 규모(수) } \\
\text { (4) 해외자본 유치노력 } \\
\text { (5) 피투자처 풀확장 } \\
\text { 노력 }\end{array}$ & $\begin{array}{l}\text { (1) 공모 투명성(개방성) } \\
\text { (2) 피투자기업 지원 } \\
\text { 및 관리 } \\
\text { (3) 과정 공정성 } \\
\text { (4) 준법.건전성 }\end{array}$ & $\begin{array}{l}\text { (1) 수익성 } \\
\text { (2) 피투자기업만족도 } \\
\text { (3) 해외매출 }\end{array}$ & $\begin{array}{l}\text { (1) 고용증가(m/h) } \\
\text { (2) 산업육성기여 } \\
\text { (3) IP수익창출(OSMU) } \\
\text { (4) 투자기업성장성 } \\
\text { (5) 생존율 } \\
\text { (6) 산업분산도 } \\
\text { (7) 국가브랜드제고 }\end{array}$ \\
\hline
\end{tabular}




\section{다. 가중치 산정}

- 개발한 모태펀드 문화계정 지표의 평가기준이 다수이며 복합적으로 이루져 있 으므로 계층적분석법(Analytic hierarchy processes, AHP)을 활용하여 가 중치를 산정

- AHP를 통하여 복잡한 문제를 계층화하여 주 요인과 세부 요인들로 나누고 요인들에 대한 쌍대비교를 하기위해 문화계정 관련 전문가들을 대상으로 설문조사를 진행

- 대분류와 세분류, 프로젝트투자와 기업투자 부분의 세부지표를 각각 산정하 여 가중치를 도출

〈표 9〉프로젝트투자 세분류 가중치 및 중요도(배점)

\begin{tabular}{|c|c|c|c|c|c|}
\hline 구분 & 대분류 & 세분류 & 가중치 & 중요도 순위 & 배점 \\
\hline \multirow{18}{*}{$\begin{array}{c}\text { 프로젝트 } \\
\text { 투자 } \\
\text { 세분류 } \\
\text { 산정 }\end{array}$} & \multirow{4}{*}{$\begin{array}{c}\text { 투입 } \\
(48.5)\end{array}$} & 목적투자 정도 & 0.555 & 1 & 26.9 \\
\hline & & 민간자금 유치 노력 & 0.224 & 2 & 10.9 \\
\hline & & 투자 프로젝트 규모 & 0.145 & 3 & 7.0 \\
\hline & & 해외자본 유치노력 & 0.075 & 4 & 3.6 \\
\hline & \multirow{5}{*}{$\begin{array}{c}\text { 과정 } \\
(20.8)\end{array}$} & 공모 투명성(개방성) & 0.249 & 2 & 5.2 \\
\hline & & 프로젝트 지원 및 관리 & 0.292 & 1 & 6.1 \\
\hline & & 과정 공정성 & 0.189 & 3 & 3.9 \\
\hline & & 준법·건전성 & 0.123 & 5 & 2.6 \\
\hline & & 지원의 시의성 & 0.148 & 4 & 3.1 \\
\hline & \multirow{4}{*}{$\begin{array}{c}\text { 산출 } \\
(14.5)\end{array}$} & 수익성 & 0.529 & 1 & 7.7 \\
\hline & & 피투자처 만족도 & 0.248 & 2 & 3.6 \\
\hline & & 해외매출 & 0.141 & 3 & 2.0 \\
\hline & & 화제성 & 0.082 & 4 & 1.2 \\
\hline & \multirow{5}{*}{$\begin{array}{c}\text { 결과 } \\
(16.2)\end{array}$} & 고용증가 & 0.289 & 2 & 4.7 \\
\hline & & 산업육성기여 & 0.340 & 1 & 5.5 \\
\hline & & IP수익창출(OSMU) & 0.189 & 3 & 3.1 \\
\hline & & 산업집중도 & 0.099 & 4 & 1.6 \\
\hline & & 국가브랜드제고 & 0.084 & 5 & 1.4 \\
\hline
\end{tabular}


〈표 10〉기업투자 세분류 가중치 및 중요도(배점)

\begin{tabular}{|c|c|c|c|c|c|}
\hline 구분 & 대분류 & 세분류 & 가중치 & 중요도 순위 & 배점 \\
\hline \multirow{19}{*}{$\begin{array}{c}\text { 기업투자 } \\
\text { 세분류 } \\
\text { 산정 }\end{array}$} & \multirow{5}{*}{$\begin{array}{l}\text { 투입 } \\
(43.2)\end{array}$} & 목적투자 정도 & 0.455 & 1 & 19.6 \\
\hline & & 민간자금 유치 노력 & 0.202 & 2 & 8.7 \\
\hline & & 투자 기업 규모(수) & 0.159 & 3 & 6.9 \\
\hline & & 해외자본 유치 노력 & 0.079 & 5 & 3.4 \\
\hline & & 피투자처 풀확장 노력 & 0.104 & 4 & 4.5 \\
\hline & \multirow{4}{*}{$\begin{array}{c}\text { 과정 } \\
(20.3)\end{array}$} & 공모 투명성(개방성) & 0.306 & 2 & 6.2 \\
\hline & & 피투자기업 지원 및 관리 & 0.388 & 1 & 7.9 \\
\hline & & 과정 공정성 & 0.208 & 3 & 4.2 \\
\hline & & 준법·건전성 & 0.098 & 4 & 2.0 \\
\hline & \multirow{3}{*}{$\begin{array}{c}\text { 산출 } \\
(20.3)\end{array}$} & 수익성 & 0.640 & 1 & 13.0 \\
\hline & & 피투자기업만족도 & 0.250 & 2 & 5.1 \\
\hline & & 해외매출 & 0.110 & 3 & 2.2 \\
\hline & \multirow{7}{*}{$\begin{array}{c}\text { 결과 } \\
(16.2)\end{array}$} & 고용증가 & 0.217 & 2 & 3.5 \\
\hline & & 산업육성기여 & 0.218 & 1 & 3.5 \\
\hline & & IP수익창출(OSMU) & 0.149 & 4 & 2.4 \\
\hline & & 투자기업성장성 & 0.171 & 3 & 2.8 \\
\hline & & 생존율 & 0.135 & 5 & 2.2 \\
\hline & & 산업분산도 & 0.062 & 6 & 1.0 \\
\hline & & 국가브랜드제고 & 0.048 & 7 & 0.8 \\
\hline
\end{tabular}




\section{5. 시사점 및 결론}

\section{가. 연구의 시사점}

- 문화산업 특성을 반영한 성과지표 구성

- 기존의 수익성 위주의 성과 지표에서 탈피하여, 투자의 전 과정을 지표에 포괄

- 한류효과 등 직접적인 효과 측정이 어려운 문화산업의 간접 기여 정도를 성과로 측정하기 위한 항목 편성

- 장르, 출자 분야에 구애받지 않는 성과지표 도출

- 문화계정 투자의 실태를 반영하여 성과지표를 프로젝트와 기업 성과 지표 로 차별화하여 구성

- 매년 달라지는 출자분야에 상관없이 측정 가능한 일반화된 지표 구성

- 모태펀드 문화계정의 역할을 '산업고도화'측면으로 포지셔닝

- 정책금융은 모태펀드 이외에도 대출, 완성보증, 가치평가 등 다양한 수단이 존재하고 기존의 지원사업도 있으므로 모태펀드 문화계정의 역할을 '산업 고도화'로 한정함

- 공적 자금이 민간 시장에 투입되면서 시장을 더욱 투명화하고 체계화할 수 있도록 지표를 통한 방향성 제시

\section{나. 연구의 한계 및 향후 연구방향}

- 실무 적용을 위한 방안 마련

- 연구에서 도출된 지표를 실제로 적용하기 위한 시뮬레이션 과정 필요

- 연구에서 제시한 지표의 실무 적용 가능성을 높이기 위해 그 동안 모태펀드 문화계정의 실제 투자 자료를 확보하여 시뮬레이션을 시도하고자 하였으나 투자 정보 협조 상의 한계와 인적, 시간적, 물적 비용의 제한 등의 한계

- 타 정책금융 수단과의 조화 방안 마련

- 금융 분야의 정책수단은 다양한 형태가 있고, 기업 입장에서는 민간분야 금융 도 활용할 수 있기 때문에 정책금융은 수단별로 그 역할이 조정될 필요가 있음 


\section{목차}

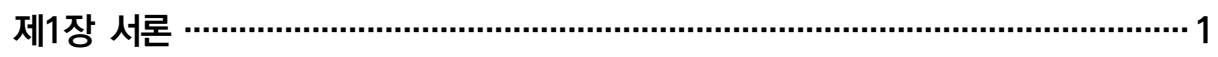

제1절 연구 배경 및 목적 3

1. 연구 배경 3

2. 연구 목적 4

제2절 연구 범위 및 방법 6

1. 연구 범위 6

2. 연구 방법 6

제2장 모태펀드 문화계정 및 성과평가 현황 ……………………………………9

제1절 모태펀드 문화계정 현황 11

1. 모태펀드의 취지와 정책 금융의 의의 11

2. 모태펀드 문화계정 기본 현황 15

3. 모태펀드 문화계정의 성과와 한계 21

제2절 모태펀드 문화계정 성과평가 현황 27

1. 모태펀드 문화계정 성과평가 개요 27

2. 모태펀드 문화계정의 기존 성과지표 분석 28

제3절 소결 33

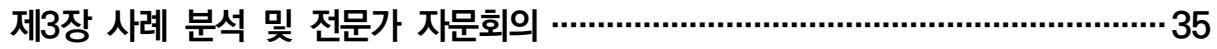

제1절 사례 분석 37

1. 사례분석 개요 37

2. 유사 정책펀드 및 정부 벤처캐피털 성과 지표 사례 분석 38

3. 콘텐츠산업 관련 성과 지표 사례 분석 46 
제2절 전문가 의견 조사 $\quad 51$

1. 자문회의 개요 51

2. 전문가 및 업계 관계자 자문회의 결과 52

제3절 소결

제4장 모태펀드 문화계정 성과지표 개발 …………………............................5 59

제1절 성과지표 개발 방향성 $\quad 61$

1. 성과지표 개선 및 개발 방향 $\quad 61$

2. 영화산업으로 본 모태펀드의 산업 고도화 역할과 산업 활성화 모델 63

제2절 문화계정 성과지표 개발 67

1. 성과지표 도출 과정 67

2. 산업발전 단계별 분석을 통한 성과지표 후보 도출 68

3. 논리모형 대입 및 최종지표 도출 72

제3절 가중치 산정 $\quad 81$

1. 가중치 산정 방법 81

2. AHP 설문 내용 및 가중치 산정 과정 83

3. 가중치 산정 결과 87

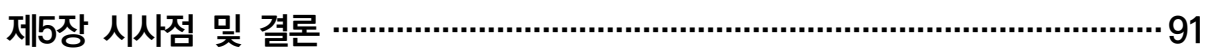

제1절 연구의 시사점 93

제2절 연구의 한계 및 향후 연구방향 96

참고문헌 / 97

ABSTRACT / 99

부록 / 101 


\section{표 목차}

〈표 2-1〉 모태펀드 주 출자 분야

〈표 2-2〉2013년 2020년 출자 분야 17

〈표 2-3〉 출자분야 및 분야별 출자 조건(2020년 기준) 18

〈표 2-4〉 모험콘텐츠 제작초기 및 소외장르 대상 세부내용 19

〈표 2-5〉 모태펀드 문화계정 운영구조 20

〈표 2-6〉벤처기업 진입 금지 업종 폐지 21

〈표 2-7〉 모태펀드 문화계정 현황('19년 기준) 22

〈표 2-8〉 2015년 모태펀드 성과 지표 28

〈표 2-9〉 2019년 모태펀드 성과 지표 31

〈표 3-1〉사례분석 대상 및 주요 내용 37

〈표 3-2〉 농식품모태펀드 성과 지표(2019년 기준) 39

〈표 3-3〉 비계량 평가 관점별 평가 단위 40

〈표 3-4〉 2019년 모태펀드 성과 지표 42

〈표 3-5〉 성장사다리펀드와 모태펀드 비교 44

〈표 3-6〉 성장사다리펀드 성과지표(2019년 기준) 45

〈표 3-7〉 지역 콘텐츠산업 경쟁력 지표 47

〈표 3-8〉 프로세스 경쟁력 평가항목 49

〈표 3-9〉 자문위원 명단 51

〈표 4-1〉 단계(투자주도단계 및 혁신주도단계 초)에 따른 필요요소별 성과평가 지표 도출 과정 71

〈표 4-2〉 투입 최종지표(안) 74

〈표 4-3〉 과정 최종지표(안)의 정의 75

〈표 4-4〉 산출 최종지표(안)의 정의 76

〈표 4-5〉 결과 최종지표(안)의 정의 76

〈표 4-6〉 모태펀드 문화계정 최종 성과지표(안) 77

〈표 4-7〉 모태펀드 문화계정 최종 성과지표(안) 79

〈표 4-8〉 프로젝트투자 대분류 가중치 및 중요도(배점) 87

〈표 4-9〉기업투자 대분류 가중치 및 중요도(배점) 87

〈표 4-10〉 프로젝트투자 세분류 가중치 및 중요도(배점) 88

〈표 4-11〉 기업투자 세분류 가중치 및 중요도(배점) 89 


\section{그림 목차}

[그림 2-1] 모태펀드의 구성 및 구성원 11

[그림 2-2] 모태펀드 문화계정 출자 단계별 과정 16

[그림 4-1] 모태펀드 문화계정 성과지표 개발 방향 및 방안 도출 과정 61

[그림 4-2] 영화산업의 변천 과정 63

[그림 4-3] 연도별 영화산업 투자수익과 모태펀드 투입액 64

[그림 4-4] 영화산업에서의 모태펀드를 통한 산업고도화 모델 66

[그림 4-5] 최종지표 도출 과정 67

[그림 4-6] 단계별 콘텐츠산업 자금조달 수단 68

[그림 4-7] 산업발전 단계별 필요 요소와 모태펀드 투입시기 70

[그림 4-8] 논리모형 구성 73

[그림 4-9] 평가지표 우선순위 도출을 위한 AHP분석 절차 82

[그림 4-10] 계층별 쌍대비교표 84 
모태펀드 문화계정 성과지표 개발 연구

\section{제1장}

서론 



\section{제1절 연구 배경 및 목적}

\section{1. 연구 배경}

- 모태펀드 문화계정은 문화산업진흥기금이 폐지된 2006년부터 조성되어 2019 년까지 총 4,022건에 대한 주요 재원역할 수행

- 모태펀드가 〈벤처기업육성에 관한 특별조치법〉에 의해 2005년부터 운영이 시작된 이후 문화계정은 문화산업진흥기금이 폐지된 2006년에 포함

- 2019년 기준으로 97개 투자조합에서 2조 1,198 억 원을 조성(모태펀드 전 체의 $8.5 \%)$

- 이 가운데 정부 출자액은 9,455 억 원이며, 출자승수 2.24 배를 기록

- 문화계정은 문화산업의 특수성으로 '수익률' 개선에 구조적인 한계가 있음에 도 불구, 타 계정과의 단순 수익률 비교로 성과측정이 이루어짐

- 모태펀드 문화계정 성과를 나타내는 주된 지표로 '수익률'이 사용되고 있고, 타 계정 대비 상대적으로 낮은 수익률로 국회 예산 삭감 등의 부정적 논리 로 활용되고 있음

- 모태펀드 문화계정의 공공적 성격이 반영된 성과지표 개발 필요문제가 지속적 으로 제기됨

- 콘텐츠산업 자체가 고수익 고위험 구조의 투자이기 때문에 물적인 가치 평 가보다 무형의 콘텐츠 자체 중심의 평가가 이루어져야 함

- 중진계정 대비 제한적인 투자대상, 기업의 영세성, 높은 투자난이도, 공공 적 출자조건(표준계약 의무화, 영화투자비율 제한, 임금체불체작자 투자금 지) 등의 구조적 특성 반영 필요 
- 정부의 콘텐츠 모험투자 활성화 방향에 걸맞는 정책방향에 맞는 성과지표 개 발의 필요성

- 콘텐츠 산업에서 자생적으로 투자가 잘 조성되지 않았던 영역에 집중 투자 하기 위해 '콘텐츠 모험투자 자금'을 별도로 설치하여 운영

- 특히, 20년부터 수익적 측면보다는 공공적 측면이 중시되는 '모험투자펀드' 를 신설, 운용할 계획으로, 정부의 계속적인 출자 당위성 확보를 위해서 조 속한 지표 개발 필요

\section{2. 연구 목적}

- 지금까지 모태펀드 문화계정 투자의 성과 및 특수성 분석

- 일반적인 제조업종과 달리 수익예측이 어렵고 고위험-고수익(High risk-High return) 특성 등 타 계정 대비 문화계정만이 지니는 특수성 분석

- 기존 수익률 위주 지표 적용의 부적절성 및 문제점 제시

- 현행 성과지표 체계에 따른 평가의 한계 및 문제점 분석

- 현행 성과지표에 의한 모태펀드 문화계정 성과 분석

- 모태펀드 문화계정의 특수성에 따른 성과지표 개선의 당위성 제시

- 성과측정이 가능하고 체감도가 높은 대체 지표 개발

- 문화계정 펀드운용으로 나타나는 효과를 정량적, 정성적으로 측정할 수 있 는 성과지표 개발

- 문화계정 펀드의 성과 및 경제사회적 파급효과를 종합 분석할 수 있는 지표 개발

- 문화계정만의 정책 목적성에 부합하는 성과지표 개발

- 프로젝트 중심의 투자, 무형의 결과물로 인한 정보의 비대칭성, 세부 장르 별 특성의 차이 등 콘텐츠 산업만의 특성을 반영 
- 펀드로서의 역할과 정책자금으로서의 역할 균형 모색

- 산업을 성장시키는 것이 정책자금의 역할이라고 본다면, 현재의 모태펀드 문화계정이 제 역할을 충분히 해 주고 있는지 점검은 반드시 필요

- 단순히 펀드라는 이름에 묶여서 산업화의 영역에서 충분히 활용되지 못하 고 있다면 최적화할 수 있는 다른 모양의 제도 수정이 요구됨 


\section{제2절 연구 범위 및 방법}

\section{1. 연구 범위}

- 시간적 범위

- 문화산업진흥기금 폐지 후 모태펀드가 운용되어온 2006년부터 현재 시점 까지 자료 검토

- 공간적 범위

- 국내 콘텐츠 산업 및 투자 환경 전반

- 내용적 범위

- 관련 법률 및 제도 검토

- 모태펀드 운용 현황 자료 검토

- 국내외 유사사례 검토

\section{2. 연구 방법}

- 문헌연구 및 자료분석

- 모태펀드 문화계정 관련 선행연구 및 보고서

- 정책금융의 흐름 변화, 모태펀드에 관한 저서, 성과지표 개발 관련 논문, 통계자료 
- 국내외 모태펀드 성과지표 사례 분석

- 모태펀드 타계정 등 문화계정 외에 유사정책펀드와 콘텐츠산업 성과 지표 의 사례를 분석하여 시사점을 도출하고, 해당 지표들 중에 문화계정에 활용 할 수 있는 항목 및 지표는 벤치마킹

- (분석대상) 모태펀드 타계정 및 유사 정책펀드 성과지표, 콘텐츠산업 관련 성과지표

- (방법) 지표의 일반현황과 세부 지표내용을 분석하여 세부적 특징과 지표의 구성 체계, 평가방법론 등을 분석자료

- 모태펀드 문화계정 전문가 및 업계 관계자 자문회의

- 모태펀드 운영기관(문화계정 담당자, 모태펀드 성과지표 담당자), 문화계정 출자조합 운용사(문화계정 운용 유경험 담당자), 학계 및 연구계 전문가(문 화계정 성과 관련 연구 유경험자)를 대상으로 10 차 자문회의 진행

- (목적) 실질적인 지표 개발을 위해 전문가 및 업계 관계자 자문회의를 진행 하여 모태펀드 문화계정의 현황과 문제점을 파악하고 지표개선 방안을 마련

- (기간) 2020년 5월 1일 2020년 7월 30일

- (방법) 구조화된 질문지 또는 회의 안건 제시를 통한 토론 진행, 온라인 원 격회의와 현장회의 병행

- 논리모형 활용을 통한 지표 개발

- 논리 모형을 통해 모태펀드 문화계정 구성요소와 그 관계를 각 절차에 따라 시각화하여 사업의 성격과 전 과정을 고려한 효과적인 지표 마련

- 논리모형의 투입(Input), 과정(Process), 산출(Output), 결과(Outcome) 의 4 가지 분류에 앞서 정리한 지표반영 사항을 적용하여 각 단계별로 성과 지표를 체계적으로 리스트업 
- $\mathrm{AHP}($ 계층적 분석법)를 통한 최종 지표 선정 및 가중치 설정

- 지표에 대해서 전문가를 대상으로 AHP(Analytic Hierarchy Process: 계 층적 분석법)를 활용하여 최종지표를 선정하고 가중치 적용

- 각 요인의 지표 선정 시, 각 요인들의 중요성에 따라 모태펀드 문화계정 결 과가 달라 질 수 있기 때문에, $\mathrm{AHP}$ 가중치를 각각 적용하여 산출

- 전체 평가 지표의 정교성을 높이기 위해서 중분류 세부지표 모두 AHP 분석 을 시행하여 가중치 산정 
모태펀드 문화계정 성과지표 개발 연구

제2장

모태펀드 문화계정 및

성과평가 현황 



\section{제1절 모태펀드 문화계정 현황}

\section{1. 모태펀드의 취지와 정책 금융의 의의}

\section{가. 모태펀드의 개념과 목적}

- 모태펀드(Fund of Funds)는 기업 또는 프로젝트에 직접투자하지 않고 전문 투자기관을 통해 개별 펀드에 출자하는 간접방식의 금융지원 정책

- 정부가 자금을 모아 하나의 모(母)펀드를 결성하고 모펀드를 통해 창업투자 회사(venture capital)가 결성하는 자(子)펀드에 출자하는 방식으로 운영

[그림 2-1] 모태펀드의 구성 및 구성원

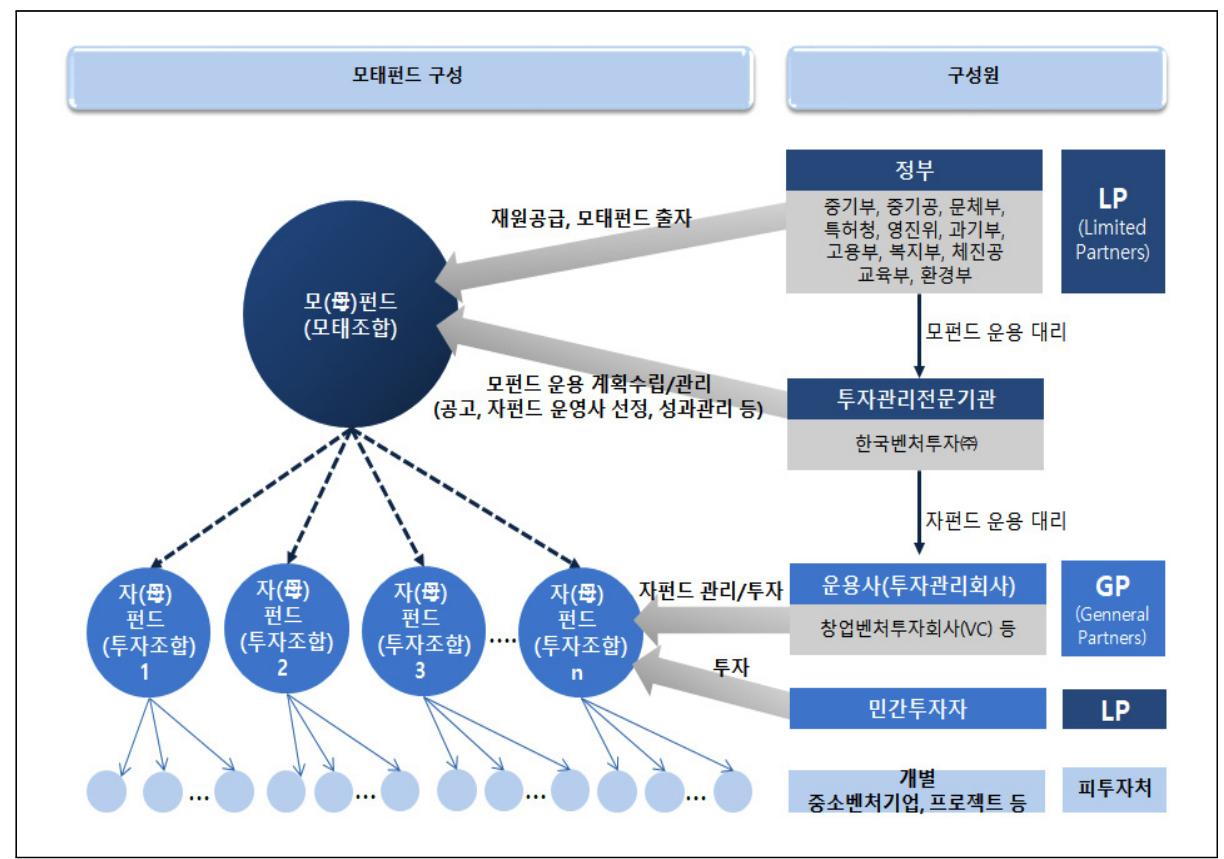


- 출자주체인 정부가 운용에 관여하지 않고 전문투자기관이 개별펀드(투자조합) 에 출자하여 운용함으로 전문적이고 효과적인 수익 창출이 가능

- 미국 등 서구에서는 헷지(hedge)펀드를 위해 모태펀드(Private Equity fund of funds)가 민간에서 만들어져 운영

- 하지만 국내에서는 정부가 출자하여 투자조합에 출자하는 형태로 산업 육 성에 기여하는 펀드가 모태펀드라고 소개되면서 모태펀드를 정부의 출자를 통해 이루어지는 정책 펀드로 용어가 한정되어 활용되고 있음

- 정부는 전략적으로 출자할 뿐 직접적인 투자를 하지 않기 때문에 투자에 대한 위험을 직접적으로 부담하지 않음

- 2005년 7월 15일부터 결성이 시작되어 운용기간은 2035년까지 30년

- 출자자인 정부 각 부처의 영역에 따라 전체 18 개의 계정으로 주 출자분야가 구성되어 있음

〈표 2-1〉 모태펀드 주 출자 분야

\begin{tabular}{c|l}
\hline 구분 & \multicolumn{1}{c}{ 내용 } \\
\hline 중진계정 & 창업초기, 지방기업, 부품소재, M\&A등에 투자하는 펀드 \\
\hline 청년계정 & 청년창업기업 투자펀드 \\
\hline 혁신모험계정 & 창업초기기업·혁신성장기업·농수산벤처기업 투자펀드 \\
\hline 소재부품장비계정 & 소재부품장비분야 투자 펀드 \\
\hline 엔젤계정 & 엔젤매칭투자조합 등 엔젤 투자 활성화를 위한 펀드 \\
\hline 지방계정 & 지방기업 투자 활성화를 위한 펀드 \\
\hline 문화계정 & 문화산업진흥기본법에 의한 문화산업에 투자하는 펀드 \\
\hline 관광계정 & 관광진흥법에 의한 관광업 등에 투자하는 펀드 \\
\hline 스포츠계정 & 스포츠산업진흥법 상 스모츠산업 산업에 투자하는 펀드 \\
\hline 영화계정 & 한국영화 등에 투자하는 펀드 \\
\hline 특허계정 & $\begin{array}{l}\text { 발명진흥법에 의한 발명활동의 진작과 발명성과의 권리화 촉진, } \\
\text { 우수 발명의 이전알선과 사업화 등 특허기술사업화 기업에 투자하는 펀드 }\end{array}$ \\
\hline 과기계정 & $\begin{array}{l}\text { 방송법, 전기통신사업법, 인터넷멀티미디어 방송사업법에 근거한 방송, 인터넷 } \\
\text { 멀티미디어, 전기통신역무제공 및 서비스 등 방송통신사업분야에 투자하는 펀드 }\end{array}$ \\
\hline 보건계정 & 보건산업에 투자하는 펀드 \\
\hline 환경계정 & 미래환경산업, 미세먼지관련 기업 투자 펀드 \\
\hline
\end{tabular}




\begin{tabular}{c|l}
\hline 구분 & \multicolumn{1}{c}{ 내용 } \\
\hline 해양계정 & 해양신산업 관련 기업 투자펀드 \\
\hline 도시재생계정 & 구도심 도시재생을 목표로 관련 기업 투자펀드 \\
\hline 국토교통혁신게정 & 국토교통혁신산업 기업 투자 펀드 \\
\hline 교육계정 & 대학창업, 학생창업 기업 투자펀드 \\
\hline
\end{tabular}

자료: 한국벤처투자

- 투자의 전문성을 기반으로 운용의 비효율을 극복하기 위한 대안

- 정부 개입에 의한 시장 왜곡을 최소화하기 위해 투자 재원의 공급은 정부가

하되, 실제 기업에 대한 투자의사결정은 전문성을 지니는 민간의 전문기관

이 진행하는 간접투자 방식을 채택

- 예산배정에 따라 투자금액이 결정되는 공급자 위주의 정책지원에서 탈피, 시장수요를 반영한 회수재원의 재순환(revolving) 방식으로 안정적 벤처투 자재원 공급체계를 마련

- '공공성'과 ‘효율성' 모두를 추구하는 이중적 목표를 지니는 정책 금융

- 정부 재원이 주된 기반으로, 정부가 추진하는 정책 방향이나 시장의 공공성

에 부합하는 투자가 이루어져야한다는 점에서 경쟁력이 상대적으로 낮은 취약 장르와 규모가 작은 기업 등을 지원해야 하는 공공적 목표성이 내재

- 반면, 민간자본이 함께 투자되며 민간 투자사들이 외부 간섭 없이 가장 적 합한 투자처를 물색할 수 있도록 설계된 체계이기 때문에 자율성을 기반으 로 수익성도 동시에 추구해야 함

- 이에 모태펀드 문화계정은 영세기업이나 애니메이션, 출판 등 취약하고 다 소 위험성이 높은 콘텐츠 산업 분야의 성장을 견인해야 하는 공공성과 동시 에 투자의 본 목적인 수익성을 창출해야하는 이중적 역할을 지님

- 즉 모험적이고 성공적인 투자로 취약한 분야의 기회를 창출하는 공공성과 수익을 창출해야하는 효율성 모두를 충족할 수 있는 가능성을 지님

- 하지만, 자칫 두 가치 모두를 놓치고 지원제도 정체성의 혼란을 야기하게 될 여지도 존재 


\section{나. 정책금융으로서의 모태펀드 의의}

- 민간 투자 및 벤처캐피탈의 시장실패 완화

- 모태펀드는 특정 산업 육성, 지역의 활성화, 벤처생태계의 조성 등 일반 민 간투자나 벤처캐피탈에서 스스로 진입하기 꺼려하는 분야에 투자가 가능하 게 하여 특정 정책목표 수립에 기여

- 정부기금을 출자함으로써 투자 고위험군에 투자가 상대적으로 용이하게 되 어 벤처캐피탈의 공공적 투자 부진 문제를 해결

- 초기창업기업이나 위험성이 높은 불확실한 사업아이디어에도 시장에서 자본 이 조달될 수 있도록 도와주는 역할 수행

- 아직 시장에 일반인의 창업투자자금이 충분히 모이지 않은 환경에서는 모 태펀드가 운용사의 펀드조성에 상당히 큰 힘이 되며 일반투자자를 창업기 업투자로 유도하는 마중물의 역할 수행

- 모태펀드는 펀드의 출자액 중 상당부분을 정부출자가 차지하기 때문에 운 용사 입장에서는 모태펀드의 출자를 받아내면 LP들을 적은 수만 모집하여 도 펀드규모의 임계량 충족 가능

- 정보비대칭 문제를 해소하여 중소벤처기업들에게 자금을 원활하게 조달하는 기능

- 모태펀드를 통한 투자방식은 투자자에게 잘 알려지지 않은 기업 및 프로젝 트 정보를 벤처캐피탈(VC)를 통하여 시장에 알리는, 정보비대칭문제의 해 결 역할을 수행

- 자펀드 결성과정에서 민간투자를 유치해야하기 때문에 자펀드 운용사들은 투자대상 기업과 프로젝트의 정보를 효과적으로 정제화하고 그 과정에서 이해관계자들에게 정보들을 노출

- 운용사의 자펀드 운용의 투명성과 전문성을 제고

- 모태펀드로부터 출자를 받을 때는 회계감사, 투자심의위원회, 자펀드에 대 한 평가와 해산과 청산, 운영인력 및 관리보수 등 자펀드의 운영과 투자 및 사후관리에 대한 비교적 상세한 관리를 받게 됨 
- 자펀드 운용에 대한 투명한 관리로 인해 GP의 도덕적해이가 축소되고 GP 의 전문성이 높아져 펀드가 더 높은 성과를 내고 일반투자자로부터 신뢰도 가 제고되는 효과발생

\section{2. 모태펀드 문화계정 기본 현황}

\section{가. 모태펀드 문화계정 설치 배경}

- 1999 년 설치된 '문화산업진흥기금’이 콘텐츠산업을 지원하는 주된 역할 담당 하다 2004년 폐지

- 문화산업진흥기금은 1999 년부터 5년간 국고 2,500억 원을 출연하기로 결 정하고 2003년까지 당초 계획보다는 조금 못 미치는 2,200억 원을 출연하 면서 설치

- 하지만 전체 기금에서 사업비로는 31\%정도만을 사용하고 약 $69 \%$ 규모의 금액이 은행에 그대로 예치되는 등 사실상 활용도가 낮았다는 지적을 받음 - 이에 따라 기금 존치평가가 2004년에 이루어졌고 기금 간 중복지원으로 자 원의 낭비와 비효율을 초래하고 있다고 보고 5 개의 기금 폐지 목록에 문화 산업진흥기금이 포함됨

- 문화산업진흥기금은 2006 년까지만 운용되었고, 같은 해 문화산업진흥기본법 의 개정을 통해 모태펀드 내 문화산업 별도계정에 출자하기로 결정

- 결과적으로 모태펀드 문화계정은 문화산업진흥기금의 재원을 이어받아 2,900 억 원 규모의 재원으로 조성되어 처음으로 출자됨

\section{나. 모태펀드 문화계정 출자 과정 및 출자 분야}

- 모태펀드 문화계정은 모태펀드 운용계획수립, 예산수립, 자펀드 공고, GP선 정, 자펀드 운용계획 수립, 민간투자유치, 투자 등 각 주체별 역할에 따라 체계 적으로 출자가 이루어짐 
- 먼저, 문화체육관광부에서 연도별로 모태펀드 운용계획을 수립하고 그에 따 라 출자분야와 예산을 배정

- 투자관리전문회사인 한국벤처투자는 문화체육관광부의 운용계획에 따라 출 자분야를 구성하고 심사과정을 거쳐 각 분야에 자펀드 운용사를 선정

- 선정된 운용사는 주목적 분야를 중심으로 자유롭게 투자유치와 자펀드 운 용계획을 수립하고 목표 결성액이 충족되면 본격적으로 투자 및 운용 활동 을 개시

- 투자 및 성과 결과는 한국벤처투자가 제시하는 성과지표 및 관리 체계에 따라 진행하여 제출

[그림 2-2] 모태펀드 문화계정 출자 단계별 과정

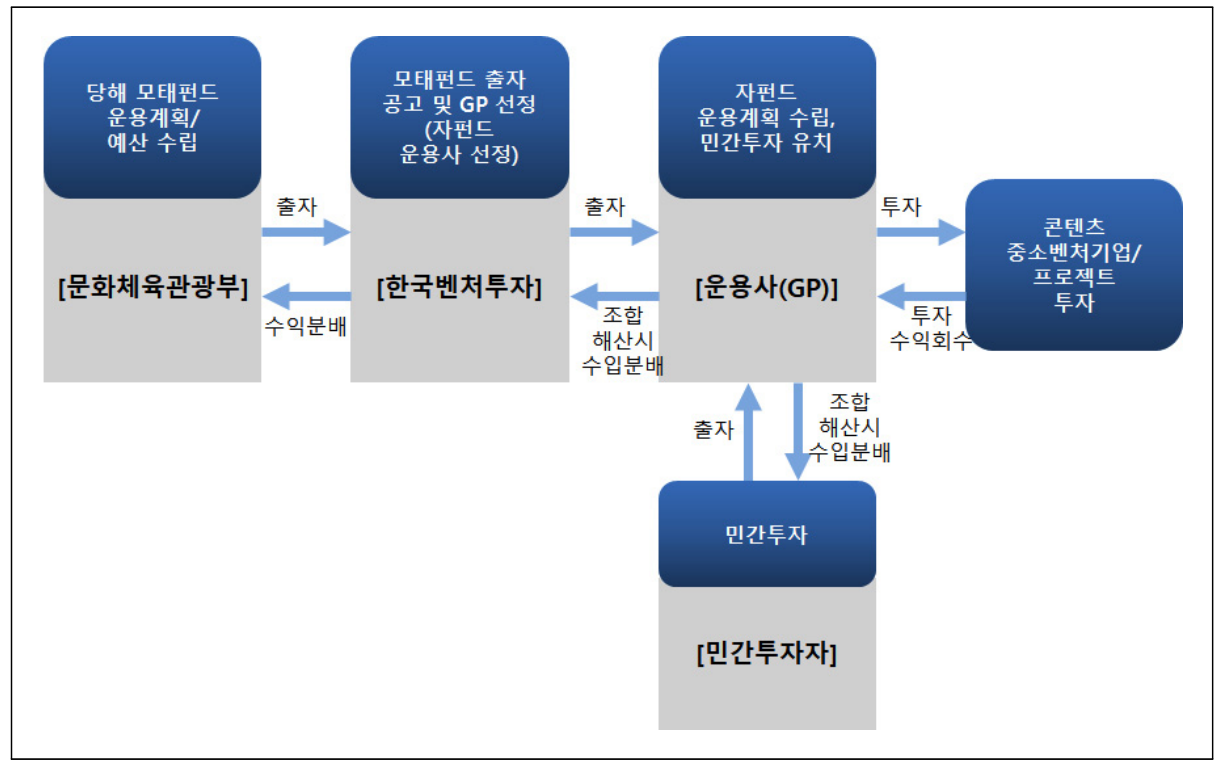

- 매년 집중 투자가 필요한 장르 또는 정책목표를 중심으로 출자분야를 선정하 여 출자를 진행

- 문화계정의 출자분야는 매년 문화체육관광부에서 보통 적게는 4 개, 많게는 6개 정도의 분야를 정책방향에 맞춰 설정하고 한국벤처투자에서는 이에 맞 춰 출자공고를 내 각 분야의 자펀드 운용사를 선정 
- 최근 8 년간의 출자분야를 분석해보면 장르 출자분야와 정책목표 출자분야로 구분할 수 있음

- 장르 출자분야는 애니메이션·캐릭터, 게임, 공연·음악, 방송 등 전략적으로 투자를 강화할 필요가 있는 특정장르에 대해서 출자하여 해당 장르 투자에 의무투자비율을 갖는 분야

- 정책목표 출자분야는 해외개척, 기술융합, 취약분야 등 해당 년도의 지원정 책방향에 맞춰 목표를 수립하고 그에 맞게 의무 출자비율을 설정한 분야

〈표 2-2〉2013년 2020년 출자 분야

\begin{tabular}{|c|c|c|c|c|}
\hline 구분 & 2013년 & 2014년 & 2015년 & 2016년 \\
\hline 장르 & - 애니·캐릭터 & $\begin{array}{l}\text { - 게임 } \\
\text { - 애니·만화·캐릭터 }\end{array}$ & $\begin{array}{l}\text { - 공연·음원 } \\
\text { - 방송 영상 }\end{array}$ & 없음 \\
\hline $\begin{array}{l}\text { 정책 } \\
\text { 목표 }\end{array}$ & $\begin{array}{l}\text { - 재무적출자자 } \\
\text { - 제작초기 } \\
\text { - 글로벌 콘텐츠 }\end{array}$ & $\begin{array}{l}\text { - 재무적출자자 } \\
\text { - 제작초기 } \\
\text { - 글로벌 콘텐츠 }\end{array}$ & $\begin{array}{l}\text { - 기획개발(제작초기) } \\
\text { - 콘텐츠영세기업 } \\
\text { - 재무적출자자 } \\
\text { - 한·중 문화산업공동 } \\
\text { 발전 }\end{array}$ & $\begin{array}{l}\text { - 영세기업\&제작초기 } \\
\text { - 가치평가 연계 } \\
\text { - 융합콘텐츠 } \\
\text { - CG\&애니메이션 } \\
\text { - 한·중 문화산업공동 } \\
\text { 발전 } \\
\text { - 문화-ICT융합 }\end{array}$ \\
\hline 구분 & 2017년 & 2018년 & 2019년 & 2020년 \\
\hline 장르 & - 방송 - 드라마 & $\begin{array}{l}\text { - 게임 } \\
\text { - 애니·캐릭터 } \\
\text { • 출판 }\end{array}$ & $\begin{array}{l}\text { - 공연 } \\
\text { - 게임 }\end{array}$ & $\begin{array}{l}\text { - 게임 } \\
\text { • 애니메이션·캐릭터 }\end{array}$ \\
\hline $\begin{array}{l}\text { 정책 } \\
\text { 목표 }\end{array}$ & $\begin{array}{l}\text { - 콘텐츠기업육성 } \\
\text { - NEW콘텐츠 } \\
\text { - 소액투자전문 }\end{array}$ & $\begin{array}{l}\text { - 일자리 } \\
\text { - 해외개척 }\end{array}$ & $\begin{array}{l}\text { - 청년콘텐츠 } \\
\text { - 지역콘텐츠 } \\
\text { • 콘텐츠 민간제안 }\end{array}$ & $\begin{array}{l}\text { • 해외연계 } \\
\text { • 콘텐츠 IP } \\
\text { • } 5 \mathrm{G} \text { 기술융합 콘텐츠 } \\
\text { • 모험 콘텐츠 }\end{array}$ \\
\hline
\end{tabular}

자료: 문화체육관광부(2013 2020)

- 2020년의 출자분야를 구체적으로 살펴보면, 애니메이션·캐릭터, 해외연계, 콘 텐츠IP, $5 \mathrm{G}$ 기술융합 콘텐츠, 모험콘텐츠, 이렇게 6개 분야로 구성 
〈표 2-3〉출자분야 및 분야별 출자 조건(2020년 기준)

\begin{tabular}{|c|c|c|c|}
\hline 분야 & 주목적투자대상 & 투자의무(주목적투자) 비율 & 출자조건 \\
\hline 게임 & - 게임 관련 프로젝트 및 기업 & $\begin{array}{l}\text { 약정총액의 } \\
60 \% \text { 이상 }\end{array}$ & $\begin{array}{c}\text { 모태출자 비율 } \\
50 \%\end{array}$ \\
\hline $\begin{array}{l}\text { 애니메이션 } \\
\text { 캐릭터 }\end{array}$ & $\begin{array}{l}\text { - 애니메이션 또는 캐릭터 관련 } \\
\text { 기업 및 프로젝트 }\end{array}$ & $\begin{array}{l}\text { 약정총액의 } \\
60 \% \text { 이상 }\end{array}$ & $\begin{array}{l}\text { 모태출자 비율 } \\
\quad 70 \%\end{array}$ \\
\hline 해외연계 & $\begin{array}{l}\text { - 글로벌 콘텐츠 및 글로벌 콘텐츠 } \\
\text { 관련 중소·벤처기업 및 프로젝트 }\end{array}$ & $\begin{array}{l}\text { 약정총액의 } \\
60 \% \text { 이상 }\end{array}$ & $\begin{array}{l}\text { 모태출자 비율 } \\
\quad 60 \%\end{array}$ \\
\hline 콘텐츠|P & $\begin{array}{l}\text { - 원첸IP (소설, 웹툰 등 타분야로의 } \\
\text { 활용이 가능한 } 1 \text { 차 창작 콘텐츠 등) } \\
\text { 및 저작재산권을 활용하는 } \\
\text { 프로젝트 }\end{array}$ & $\begin{array}{l}\text { 약정총액의 } \\
60 \% \text { 이상 }\end{array}$ & $\begin{array}{l}\text { 모태출자 비율 } \\
\quad 60 \%\end{array}$ \\
\hline $\begin{array}{l}5 \mathrm{G} \\
\text { 기술융합 } \\
\text { 콘텐츠 }\end{array}$ & $\begin{array}{l}\text { - 문화산업과 } 5 \text { 세대 기술 (VR, AR, } \\
\text { 홀로그램, VFX 등 ICT 기술)이 } \\
\text { 융합된 콘텐츠를 개발하는 중소. } \\
\text { 벤처기업 및 프로젝트 }\end{array}$ & $\begin{array}{l}\text { 약정총액의 } \\
60 \% \text { 이상 }\end{array}$ & $\begin{array}{c}\text { 모태출자 비율 } \\
50 \%\end{array}$ \\
\hline $\begin{array}{l}\text { 모험 } \\
\text { 콘텐츠 }\end{array}$ & $\begin{array}{c}\text { - 기획개발 등 제작초기 및 소외분야 } \\
\text { 제작 중소·벤처기업 및 프로젝트 }\end{array}$ & $\begin{array}{l}\text { 약정총액의 } \\
70 \% \text { 이상 }\end{array}$ & $\begin{array}{c}\text { 모태출자 비율 } \\
75 \%\end{array}$ \\
\hline
\end{tabular}

자료: 문화체육관광부(2020)

- 게임 분야는 게임 콘텐츠 프로젝트 및 게임 영위 기업에 양적총책의 $60 \%$ 이상이 투자되어야 결성이 가능하며, 약정총액의 $20 \%$ 이상은 창업 3 년 이 내 기업의 프로젝트 및 지분에 투자해야 함

- 애니메이션·캐릭터 분야는 애니메이션이나 캐릭터 장르의 프로젝트나 기업 에 투자하는 출자분야로, 약정 총액의 $60 \%$ 이상을 해당 분야에 투자해야 결 성이 가능

- 해외연계는 해외 프로젝트, 해외 공동제작 프로젝트, 해외자본 유치 프로젝 트 등 글로벌 콘텐츠 관련 중소벤처기업 및 프로젝트에 60\%이상 투자해야 결성이 가능한 출자 분야

- 콘텐츠IP는 소설이나 웹툰과 같이 타 분야로의 활용이 가능한 1 차 콘텐츠 인 문화콘텐츠 원천 IP 및 저작재산권을 활용한 기업 및 프로젝트를 대상으 로 한 출자분야

- 5G 기술융합 콘텐츠는 문화산업과 $5 \mathrm{G}$ 기술(VR, AR, 홀로그램, VFX 등)이 융합된 콘텐츠를 개발하는 중소·벤처기업 및 프로젝트 
- 모험콘텐츠는 최근 신설된 분야로 기획개발 등 제작초기분야 및 투자 소외 분야 프로젝트 또는 관련 기업을 대상으로 한 분야

〈표 2-4〉 모험콘텐츠 제작초기 및 소외장르 대상 세부내용

\begin{tabular}{c|l}
\hline 분야 & \multicolumn{1}{c}{ 해당 세부내용 } \\
\hline \multirow{5}{*}{ 제작초기 } & (1) 영화: 메인투자 계약 전, 시나리오·캐스팅(주·조연) 완료 전 (동시 충족) \\
(2) 애니: 메인투자 계약 전 \\
(3) 공연: 대관 계약 전 \\
(4) 드라마: 방솟사 편성 계약 전 \\
(5) 게임: 퍼블리셔 계약 전 및 CBT 전 \\
(6) 웹툰제작: 유통 플랫폼 (인터넷 포탈서비스 등)에 연재계약 전 \\
(7) 1인 창조기업이 제작하는 프로젝트 \\
(8) 음원: (온/오프라인) 유통사와의 유통계약 전 \\
(9) 크라우드펀딩을 유치한 프로젝트 및 기업 \\
(10) 원천스토리(시놉시스, 트리트먼트 등 출판원고 혹은 시나리오 이전 단계의 창작물)를 \\
활용한 프로젝트 및 기업 \\
(11) 기타 특별조합원이 초기단계라고 인정하는 경우
\end{tabular}

자료: 문화체육관광부(2020)

\section{다. 모태펀드 문화계정 관련 정부의 정책방향}

- 자금시장 사각지대(기획개발, 제작초기, 소외장르 등)를 지원하기 위한 정책금 융 신설 및 기존 정책금융 규모 확대2)

- 제작 초기 단계의 프로젝트 등 그간 투자가 미진했던 분야에 집중 투자하기 위해 '콘텐츠 모험투자 자금'을 대규모로 조성, 콘텐츠 모험분야 투자 확대

2) 콘텐츠산업 3대 혁신 전략, 관계부처 합동(2019) 
- 모태펀드 문화계정 내에 기획개발·제작초기·소외장르(애니메이션, 출판, 음 원 등)에 집중 투자하는 펀드로 기존 투자 사각지대 해소 목적

- 상대적으로 높은 위험성으로 투자를 회피되는 분야의 자금인 만큼 모험자 본으로서의 성격을 강화하고 신속하게 조성·공급할 수 있도록 정부 출자비 율을 $75 \%$ 까지 상향

- 모험콘텐츠 분야 신규 자조합에 한하여 투자 건별로 원금 이상 회수한 금액 (수익)에 대해서만 재투자 허용

- 또한 장르제한이 없는 모험콘텐츠 분야에 한정하여, 지분투자 비율을 약정 총액의 $20 \%$ 이상으로 의무화, 이를 통해 중소콘텐츠 제작업체 발굴·활성화

〈표 2-5〉 모태펀드 문화계정 운영구조

\begin{tabular}{|c|c|c|c|}
\hline 구분 & 목적 & 출자 분야(예시) & 비고 \\
\hline $\begin{array}{l}\text { 일반 } \\
\text { 투자 } \\
\text { 펀드 }\end{array}$ & $\begin{array}{c}\text { 산업경쟁력 강화 } \\
\text { 중소기업 육성 }\end{array}$ & $\begin{array}{l}\text { - 뉴(NEW)콘텐츠펀드 } \\
\text { - 기업지분투자전문펀드 } \\
\text { - 콘텐츠 민간제안펀드 }\end{array}$ & $\begin{array}{c}\text { 투자 자율성 강화 } \\
\text { (주목적 투자비율 완화 } \\
\text { 장르제한 최소화 등) }\end{array}$ \\
\hline $\begin{array}{l}\text { 모험 } \\
\text { 투자 } \\
\text { 펀드 }\end{array}$ & $\begin{array}{l}\text { 초기단계 투자 } \\
\text { 취약장르 지원 }\end{array}$ & $\begin{array}{l}\text { - 제작초기/기획개발 } \\
\text { - 애니메이션,출판,음원 } \\
\text { - 소액투자 전문펀드 }\end{array}$ & $\begin{array}{c}\text { 펀드운용 인센티브 제공 } \\
\text { (정부출자비중 } \\
\text { 상향조정 등) }\end{array}$ \\
\hline
\end{tabular}

자료: 문화체육관광부(2020)

- 모태펀드 등 간접지원 중심으로 지원체계 전환

- 그간 제작지원 사업 등 직접지원 중심으로 이루어진 지원사업 체계를 정부 가 간접지원 중심으로 전환을 시도함에 따라 모태펀드의 규모와 대상이 더 욱 확대될 전망

- 콘텐츠진흥원 예산(3,401억 원, 2019년 기준) 중 직접지원 38\%, 간접지원 $62 \%$ 인 예산 비중을 점진적으로 직접지원은 $25 \%$, 간접지원은 $75 \%$ 수준으 로 전환할 계획3)

- 5G 기술융합 콘텐츠, 콘텐츠 IP, 한류콘텐츠 등 성장잠재 분야에 대한 자금조 달 활성화

3) 콘텐츠산업 3대 혁신 전략, 관계부처 합동(2019) 
- 문화산업과 $5 \mathrm{G}$ 기술이 융합된 콘텐츠 활성화를 위한 ‘ $5 \mathrm{G}$ 기술융합 콘텐츠’ 분야와 문화콘텐츠 원천 IP 및 저작재산권 활용 강화를 위한 '콘텐츠 IP' 분야를 신설하여 출자

- 민간투자 확대를 위한 제도 정비

- 콘텐츠산업이 포함된 서비스업을 중심으로 벤처기업 진입금지 업종을 폐지 하여, 벤처기업 진입기회 확대

〈표 2-6〉벤처기업 진입 금지 업종 폐지

\begin{tabular}{l|l|l}
\hline \multicolumn{3}{|c}{ (현행) 23개 금지 업종 } \\
\hline (1) 여관업 & (9) 기타 부동산 임대업 & (17) 이용업 \\
(2) 그 외 기타 숙박업 & (10) 주거용건물 개발 및 공급업 & (18) 두발미용업 \\
(3) 일반유흥 주점업 & (11) 비주거용건물 개발 및 공급업 & (19) 피부미용업 \\
(4) 무도유흥 주점업 & (12) 기타 부동산 개발 및 공급업 & (20) 기타미용업 \\
(5) 기타 주점업 & (13) 골프장 운영업 & (21) 욕탕업 \\
(6) 비알콜 음료점업 & (14) 노래연습장 운영업 & (22) 마사지업 \\
(7) 주거용건물 임대업 & (15) 무도장 운영업 & (23) 기타 미용 관련 \\
(8) 비주거용건물 임대업 & (16) 기타 갬블링 및 베팅업 & 서비스업 \\
\hline
\end{tabular}

(개선) 5 개로 축소

1. 일반유흥 주점업

2. 무도유흥 주점업

3. 기타 주점업

4. 무도장 운영업

5. 기타 사행시설 관리 및 운영업

* (표준산업분류 10차 개정('17.7월)에 따른 명칭 변경 반영)

자료: 문화체육관광부(2019)

- 문화계정 제도개선 출자조건(11개)을 전면 재검토 하는 등 민간운용사의 투 자 자율성 및 펀드 운용의 투명성 강화를 위한 출자조건 등 제도를 개선

\section{3. 모태펀드 문화계정의 성과와 한계}

\section{가. 모태펀드 문화계정의 성과}

1) 콘텐츠 투자 기반 확보

- 모태펀드 문화계정은 2006년부터 조성되어 2019년까지 총 4,022건에 2조 3,471 억 원 투자 진행 
〈표 2-7〉 모태펀드 문화계정 현황('19년 기준)

(단위: 억원)

\begin{tabular}{c|c|c|c|c|c|c|c|c|c|c|c}
\hline 구분 & '10 & '11 & '12 & '13 & '14 & '15 & '16 & '17 & '18 & '19 & 합계 \\
\hline 조성액 & 5,918 & 2,410 & 200 & 1,190 & 355 & 2,989 & 2,231 & 1,221 & 2,036 & 2,648 & 21,198 \\
\hline $\begin{array}{c}\text { 투자 } \\
\text { 금액 }\end{array}$ & 4,379 & 2,414 & 2,396 & 2,215 & 2,151 & 2,059 & 2,023 & 1,801 & 1,658 & 2,375 & 23,471 \\
\hline $\begin{array}{c}\text { 투자 } \\
\text { 건수 }\end{array}$ & 864 & 437 & 419 & 414 & 367 & 306 & 330 & 282 & 283 & 320 & 4,022 \\
\hline
\end{tabular}

자료: 문화체육관광부(2019)

- 2019년 기준으로 97개 투자조합에서 2조 1,198억 원을 조성(모태펀드 전 체의 $8.5 \%$ )하였고, 이 가운데 정부 출자(약정)액은 9,455 억 원으로 출자승 수 2.24 배를 기록

- 총 1,291 개 기업을 대상으로 투자가 이루어졌으며 이들 중 3년 이하의 기 업이 약 $51 \%, 5$ 년 이하는 $69 \%$ 를 차지하는 등 초기기업에 초점을 두고 투 자 진행

\section{2) 산업 고도화 유도}

- 도입기를 넘어 본격적으로 성장과 투자가 적극적으로 필요한 시점이었던 일부 콘텐츠산업의 “산업고도화”를 이끌면서 마중물 역할을 수행

- 기반이 약하여 실패확률이 높아 투자되지 않은 분야의 투자를 활성화시켜, 근본적으로 산업 성장의 기회를 제공하고 고도화하는데 기여

- 실제로 콘텐츠 산업에서 모태펀드의 지원을 가장 많이 받은 장르인 영화는 문화계정과 영화계정의 투자를 통해 신진 제작자들과 구성원들이 성장할 수 있는 기회를 제공

- 예를 들어, 봉준호 감독은 〈괴물〉의 전체 제작비 143 억 원에서 약 $7 \%$ 규모 를, 〈마더〉의 전체 제작비 93 억 원에서 약 $22 \%$ 규모를, 〈설국열차〉의 전체 제작비 530억 원에서 약 $1 / 3$ 규모를 모태펀드에서 투자를 유치

- 이러한 투자를 통한 시도가 밑거름이 되어 스타 감독으로 성장하게 되고, 결국 〈기생충〉이라는 작품을 통해 오스카 4관왕 등 주요 영화시상식을 휩 쓸며 전 세계적으로 주목받는 스타 제작자로 자리매김 
- 운용사의 관리를 통해 전문성과 투명성을 제고하고, 투자 시 규약으로 제도 정착에 기여하여 산업으로의 면모를 갖추도록 이끎

- 콘텐츠산업 성장 초기에는 영세기업을 중심으로 주먹구구식 운영이 이루어지 는 경우가 많았으나 문화계정의 투자를 받을 경우 운용사의 관리를 받게 됨 - 운용사들은 문화전문회사(SPC) 등의 제도를 통해 프로젝트 투자에서도 회 계 감사 절차를 투명화하고, 일부 운영사들은 투자된 기업이나 프로젝트가 좋은 성과를 거두게 하도록 컨설팅의 역할도 진행

- 표준계약서 의무화, 임금체불제작사 투자 금지, 원금상환약정 금지, 공연전 산망 연계 의무화 등 투자조항에 제도를 연계하여 산업기반을 다지기위한 제도 정착에 기여

- 초기 기업투자를 통해 유니콘 콘텐츠 기업 창출

- (주)블루홀은 지난 2009년 초기 자금이 바닥나 추가 투자 유치가 시급한 상황 에서 모태펀드의 출자를 받아 2011년 1월 다중접속역할수행게임(MMORPG) '테라'를 개발하여 게임시장에 성공적으로 안착

- 이러한 투자를 기반으로 누적 판매량 5,000만 장 이상을 기록한 '배틀그라 운드'를 개발하여 전 세계적인 성공을 거두었고 최초투자 시 700억 수준이 었던 블루홀의 기업가치도 5조 원 수준으로 70 배 이상 성장

\section{나. 모태펀드 문화계정의 한계}

\section{1) 구조적 문제점}

- 타 모태펀드 계정에 비해 낮은 수익률

- 수익을 내지 못하면 모태펀드의 투자자금 원금이 줄어듦을 의미하며, 투자 재원의 감소를 가져오고 장기적으로 모태펀드 규모의 축소와 함께 투자의 위축 초래

- 모태펀드 문화계정에서 자펀드에 출자한 금액의 평가액이 2017년에는 $-27.56 \%$ 를 기록하고, 수익률이 확정된 청산펀드의 수익률도 $-3.82 \%$ 를 기 록하는 등 수익률 관련 정량적인 성과 측면에서 낮은 결과가 나타남 
- 특히, 공공성의 특성을 많이 지니는 문화계정의 특수성이 반영되지 못하고 일괄적으로 수익률 중심으로 모태펀드의 성과평가 체계가 구성되어 있기 때문에 수익률 저하의 문제는 모태펀드 문화계정 지속 명분에서 취약점

- 영세기업의 투자유치가 어려운 콘텐츠산업의 구조적 한계

- 콘텐츠산업 구성원의 대다수가 영세기업임에도 불구 재무제표 등을 통한 회사가치, 물적 담보 능력 등에서 투자를 받기에 불리한 위치에 있어 투자 유치가 난이

- 콘텐츠는 결과물 자체가 무형이고 제작환경의 특성으로 인해 프로젝트 중심 으로 투자가 이루어지고 있으며, 고수익-고위험 구조를 지니기 때문에 물적 가치보다 콘텐츠 자체의 가치를 평가해야 함에도 현실적으로는 그렇지 못함

- 최근 게임의 경우 모바일게임 시장 경쟁이 심화로 상대적으로 소규모 게임 사들에 대한 투자 심리가 위축되고 소규모 게임사가 개발한 게임이 크게 부 각되지 않아 대규모 게임사에게 투자가 집중되는 경향이 나타남

- 모태펀드의 운용 특성 상 위험성은 높고 수익성이 낮은 영세기업보다는 안 정성이 높은 기업에 투자가 몰릴 수밖에 없으며, 이에 따라 직접투자 유치 가 어려운 영세기업은 투자기관이나 대상에 종속적인 성향이 나타남

- 결과물의 무형 특성으로 인한 정보의 비대칭성 존재

- 콘텐츠산업은 무형의 결과물들이 대부분이기 때문에 자금 수요자와 공급자 간 정보 비대칭성이 매우 크게 나타나 자금조달이 매우 어려움

- 아이디어 기반의 인력 중심의 시장이며, 프로젝트성 투자가 주를 이루어지 기 때문에 유형자산 자체가 적고 제작과정에서도 완성 리스크가 커 전체적 으로 투자 안정성이 낮음

- 자금조달 갭(gap)4)은 연간 최소 9,378억 원에서 최대 2조 1,903 억원 으로 추정됨5)

\footnotetext{
4) 필요한 자금을 대출 혹은 지원받는데 성공하지는 못했으나 생존 가능한 콘텐츠 기업들의 비중을 의미. 자금 조달에 실패한 콘텐츠기업들의 비중에 이들 기업들의 평균 투융자 필요자금을 고려하여 자금조달 갭(Loan Financing Gap: LFG)을 계산함으로써 추정

5) 한국콘텐츠진흥원(2018)
} 
- 콘텐츠산업의 자금조달 갭이 크게 나타난 이유는 다양한 자금조달 수 단이 활성화 되어 있지 못하기 때문

- 전략적 투자자(SI)의 활동과 같은 시장교란으로 투자 효율성 문제

- 정책투자의 규정에서 금지 사항인 이해관계자 연관 투자가 관행상으로는 암묵적으로 진행되고 있음

- 일반조합원으로 참여한 전략적 투자자(SI, Strategic Investor)가 프로젝트 투자에 참여함으로써 제한되어 있는 투자 관련 재원이 일부 프로젝트 투자 에 쏠리는 편중이 나타나고 있는 실정

- 실제 영화투자에서는 모태펀드의 전체 투자액 중 LP 관련 투자가 약 절반 가량에 이르며 총 투자건수는 절반이상을 상회한 것으로 나타남6)

\section{2) 콘텐츠 산업만의 특성을 미반영}

- 문화계정은 타계정과 달리, 투자를 통한 '문화산업 활성화'라는 문화체육관광 부의 정책 취지가 부합해야함에도 다소 중소벤처기업 활성화를 위한 모태펀드 의 기본취지에 정책방향이 쏠려 있음

- 현재 제조업 지원을 목적으로 하는 '중소기업 지원법' 등은 콘텐츠산업과 관련성이 적어 콘텐츠 투자제도 운영에 한계 뚜렷

- 모태펀드가 '벤처기업육성에 관한 특별법'에 의해 만들어 졌고 이를 중기부 가 관리함에 따라 문화체육관광부가 문화콘텐츠산업의 특성을 반영하여 정 책적으로 필요한 부문에 자금을 관리할 수 없는 상황

- 콘텐츠산업의 대부분이 영세기업으로 구성되어 있고, 재무제표 등을 통한 회사가치, 물적 담보 능력 등은 그대로 콘텐츠 기업에 적용

- 기존의 기준보다는 고수익 고위험 구조에 대한 특성을 반영하고, 회사의 물 적 가치평가보다는 콘텐츠 자체에 대한 평가가 이루어져야 하며, 투자의 상 당부분이 프로젝트 투자라는 특징을 반영해야 함

6) 모태펀드 총투자액 1,050 억 원 중 LP 관련 투자가 약 514 억 원으로 $49 \%$ 에 이르며, 총투자 건수인 162건 중 91건(한국콘텐츠진흥원, 2018) 
- 특정 장르 투자 편중성에 따른 공적 목표 달성에 미흡

- 2019년 8월 말을 기준으로 문화계정의 총 누적투자금액(문체부 출자자금+ 민간자금)은 2조 363 억 원인데, 투자자금 중 $48.2 \%$ 가 영화

- 투자조합의 콘텐츠 상품 투자의 경우 영화, 뮤지컬, 게임 등 일부 장르에 대한 편중성이 나타나고 있음

- 소외 장르라 할 수 있는 애니메이션 등의 장르는 상대적으로 투자 비중이 낮거나 아예 투자를 외면하는 경우도 발생하고 있어, 문화콘텐츠 투자활성 화라는 정책목표 달성에 미흡한 측면이 있음

- 콘텐츠 기업의 영세성으로 인하여 상대적으로 실패가능성이 낮은 우량 대기업 에 투자가 집중되는 경향 존재

- 11 만 여개의 국내 콘텐츠기업 중 $89.9 \%$ 는 매출액의 규모가 10 억 원 미만 기업이며 종사자 규모로 보았을 때도 $91.6 \%$ 가 10 인 미만 기업일 정도로 영세하여 콘텐츠 제작을 위한 투자유치 여건에 부합하지 못함

- 콘텐츠 투자의 경우 안정성을 높이기 위해 대형 배급사와 연관되거나 협업 이 확정되어 있는 콘텐츠 투자를 선호 


\section{제2절 모태펀드 문화계정 성과평가 현황}

\section{1. 모태펀드 문화계정 성과평가 개요}

- 규정에 따라 조성된 모태펀드 사업이 설립 취지 및 목표를 효과적으로 달성하 고 있는지에 대하여 연차별로 점검 및 평가 진행

- 모태펀드는 중소기업 모태펀드 투자 관리기관 기준 및 투자관리 전문기관 관리규정(중소기업청 고시) 제21조에 의거 외부평가기관으로부터 모태펀드 운용에 대한 성과 평가가 의무화되어 있음

- 문화계정을 포함한 해당년도에 조성된 모태펀드 운용자금 전체를 대상으로 평가를 진행

- 현재는 매해 한국벤처투자가 외부평가기관을 통해 18 개 모태펀드 계정의 성과평가 결과를 도출

- 시장 및 환경의 변화를 반영하여 성과평가에서 개선이 필요한 사항을 수정하 여 성과지표를 보완

- 모태펀드 투자관리 전담기관 및 업무집행조합원인 한국벤처투자가 제출한 연간 운용계획, 운용실적 등 다양한 자료를 바탕으로 평가실시

- 본 연구에서는 문화계정 특화지표가 있었던 2015년 성과지표와 가장 최근 에 진행되었던 2019년 모태펀드 성과지표를 대상으로 분석을 진행 


\section{2. 모태펀드 문화계정의 기존 성과지표 분석}

\section{가. 2015년 모태펀드 성과지표}

- 6 개 전략목표, 16 개 성과목표에 따른 개별 성과지표를 37 개 구성

- 모태펀드 사업이 추구해야할 전략목표 6가지 방향성(중소·벤처기업 성장, 벤처캐피탈 산업의 성장 및 성장선진화, 중점정책과제달성, 자펀드 운용의 효율성, 모태펀드의 수익성, 자펀드 선정의 공정성과 합리성)을 기반으로 지표를 구축

- 그리고 이 6가지 전략목표를 달성하기 위한 방안이라고 할 수 있는 성과목 표들을 각각 세부적으로 구성하고, 거기에 맞는 성과지표들을 세부적으로 마련하여 모태펀드의 성과를 파악

- 중소벤처기업성장, 시장선진화와 같이 모태펀드 자체의 목표라고 할 수 있 는 거시적인 전략목표(outcome)와, 중점정책과제 달성, 수익성과 같은 세 부적 목표(output) 포함

- 또, 자펀드 운용의 효율성, 자펀드 선정의 공정성과 합리성과 같은 모태펀 드 과정(process)에 관련한 부분도 일부 포함됨

〈표 2-8〉2015년 모태펀드 성과 지표

\begin{tabular}{|c|c|c|}
\hline 전략목표 & 성과목표 & 성과지표 \\
\hline \multirow{8}{*}{$\begin{array}{l}\text { 중소·벤처기업 } \\
\text { 성장 }\end{array}$} & \multirow{2}{*}{ 투자기업성장성 } & 투자기업 총자산 증가율 \\
\hline & & 투자기업 매출액 증가율 \\
\hline & \multirow{3}{*}{ 투자기업 안정성 } & 투자기업 부채비율 \\
\hline & & 투자기업 유동비율 \\
\hline & & 투자기업 신용등급 개선 \\
\hline & \multirow{2}{*}{ 투자기업 수익성 } & 투자기업 매출 총이익률 \\
\hline & & 투자기업 자산대비 영업이익률 \\
\hline & 투자기업 고용증대 & 투자기업 고용 증가율 \\
\hline \multirow{4}{*}{$\begin{array}{c}\text { 벤처캐피탈산업의 } \\
\text { 성장 및 시장 선진화 }\end{array}$} & \multirow{4}{*}{$\begin{array}{c}\text { 벤처캐피탈산업 활성화 및 } \\
\text { 선진화 지원 }\end{array}$} & 연간 출자 한도 달성 \\
\hline & & 신규로 선정된 자펀드 운용사 비율 \\
\hline & & 중간회수시장 활성화 \\
\hline & & 이해상충 방지 \\
\hline
\end{tabular}




\begin{tabular}{|c|c|c|}
\hline 전략목표 & 성과목표 & 성과지표 \\
\hline \multirow{4}{*}{$\begin{array}{l}\text { 벤처캐피탈산업의 } \\
\text { 성장 및 시장 선진화 }\end{array}$} & 벤처캐피탈산업 글로벌화 지원 & 모태펀드 출자 자펀드의 외국자본 투자비중 \\
\hline & \multirow{3}{*}{$\begin{array}{c}\text { 모태펀드 출자 자펀드 } \\
\text { 평균 규모 증가 }\end{array}$} & 모태펀드 출자 자펀드의 평균 결성금액 \\
\hline & & $\begin{array}{l}\text { 모태펀드 출자를 통한 자펀드의 자본유입효과 } \\
\text { (레버리지) }\end{array}$ \\
\hline & & 자펀드 결성 성공률 \\
\hline \multirow{10}{*}{$\begin{array}{l}\text { 중점 정책과제 } \\
\text { 달성 }\end{array}$} & \multirow{3}{*}{$\begin{array}{l}\text { 시장실패 영역 } \\
\text { 투자 확대 }\end{array}$} & 창업초기기업 투자비중 \\
\hline & & 지방기업 투자비중 \\
\hline & & 시용위험이 높은 기업에 대한 투자비중 \\
\hline & \multirow{3}{*}{$\begin{array}{l}\text { 특허계정 정책 } \\
\quad \text { 목표 }\end{array}$} & 경제적 파급효과 \\
\hline & & 고용창출효과 \\
\hline & & 지식재산권 자산가치 창출효과 \\
\hline & \multirow{4}{*}{$\begin{array}{l}\text { 문화계정 } \\
\text { 정책 목표 }\end{array}$} & 문화계정 투자를 통한 산업 육성 \\
\hline & & $\begin{array}{l}\text { 문화계정 투자를 통한 문화향수권 개선 } \\
\text { 및 국가이미지 항상 효과 }\end{array}$ \\
\hline & & 문화계정 투자포트폴리오 산업집중도 \\
\hline & & 문화계정 자펀드의 3년간 투자진척도 \\
\hline \multirow{4}{*}{$\begin{array}{l}\text { 자펀드 운용의 } \\
\quad \text { 효율성 }\end{array}$} & \multirow{2}{*}{$\begin{array}{c}\text { 사후관리 및 } \\
\text { 운용프로세스 개선 }\end{array}$} & $\begin{array}{l}\text { 투자집행 후 사후관리 및 자펀드 운용 관련 } \\
\text { 제도 개선 노력 }\end{array}$ \\
\hline & & 자펀드의 윤리적 투명성 \\
\hline & \multirow{2}{*}{ 운용의 효율성 달성 } & 모태펀드 효율적 운용에 관한 고객만족도 점수 \\
\hline & & 자펀드 3년간 투자진척도 \\
\hline \multirow{2}{*}{$\begin{array}{l}\text { 모태펀드의 } \\
\text { 수익성 추구 }\end{array}$} & \multirow{2}{*}{ 모태펀드 수익성 } & 모태펀드 수익 배수 \\
\hline & & 미투자자산 수익률 \\
\hline \multirow{5}{*}{$\begin{array}{l}\text { 자펀드 선정의 } \\
\text { 공정성과 합리성 }\end{array}$} & 심사기준 합리성, 객관성 달성 & 심사기준을 모태펀드 운영계획상에 반영 \\
\hline & 자펀드 수시 출자 확대 & 자펀드 수시출자 약정금액 규모 \\
\hline & \multirow{3}{*}{$\begin{array}{c}\text { 자펀드 선정과정의 } \\
\text { 투명성과 공정성 달성 }\end{array}$} & $\begin{array}{l}\text { 선정과정 및 심사제도 공정성에 관한 } \\
\text { 고객만족도 점수 }\end{array}$ \\
\hline & & 출자심사기준에 관한 고객만족도 점수 \\
\hline & & 심사기준 및 절차개선 \\
\hline
\end{tabular}

자료: 한국벤처투자(2015) 
- 특히, 문화계정의 특수성을 반영하여 '문화계정 정책목표'라는 성과에 따른 4 개의 문화계정 특수지표를 구성

- 문화계정 투자를 통한 산업 육성은 영화산업 매출액 증가율과 국내영화 매 출액 증가율을 파악하여 평가

- 문화계정 투자를 통한 문화향수권 개선 및 국가이미지 향상효과는 문화소 비지출 증가율과 영화산업수출액을 통해 파악

- 문화계정 투자포트폴리오의 산업집중도는 허핀달-허쉬만 지수를 적용하여 산업집중도를 정도를 평가

- 문화계정 자펀드의 3년간 투자진척도는 자펀드 결성 후 3년 내인 자펀드의 투자기업에 투자하는 누적 투자금액과 자펀드의 총 약정액을 기준으로 가늠

- 다만, 문화계정 정책목표 지표의 대부분이 해당 산업전체에 해당되어 지나친 일반화라는 점과 영화산업에만 특화된 지표라는 한계가 있었음

- 산업매출액 증가율, 문화소비지출증가, 허핀달-허쉬만지수를 통한 투자포 트폴리오 산업집중도 등 해당 성과지표들이 모태펀드뿐 아니라 다른 요소 들과 복합적으로 발생하는 결과들

- 당시에 문화계정의 상당부분이 영화 분야에 집중되어 있었기 때문에 '문화 계정 투자를 통한 산업 육성', 국가이미지향상효과와 같은 지표는 영화산업 매출액, 점유율, 수출액으로 평가하여 타 장르에는 적용에 한계가 존재

- 전체적으로 과정(process)-산출(output)-결과(outcome)의 체계성을 갖추어 있었고, 문화계정의 특성을 반영한 지표가 존재했다는 의의가 있음

\section{나. 2019년 모태펀드 성과지표}

- 5 개 성과목표에 따른 개별 성과지표를 12 개 구성

- 지표와 절차의 복잡성에 대한 지적으로 성과목표는 5 개로 1 개만 줄었지만, 성과목표를 따로 두지 않고 성과지표를 대폭 간소화하여 12 개의 지표체계 로 성과평가를 진행 
- 상대적으로 기존 전략목표들이 중소벤처기업 성장과 같은 거시적인 내용으 로 이루어졌다면, 현재 지표는 모태펀드의 경제적, 수익적 성과 등 미시적 관점의 성과목표를 설정하여 지표를 구성

- 모태펀드 투자금액 확대, 집중육성분야투자금액확대, 민간 LP참여, 투자기 업 성과관리, 모태펀드 수익률 제고와 같이 계량적이고 직관적인 성과목표 를 위주로 성과체계가 이루어짐

〈표 2-9〉2019년 모태펀드 성과 지표

\begin{tabular}{c|l}
\hline \multirow{2}{*}{$\begin{array}{c}\text { 성과목표 } \\
\text { 투자펌엄드 확대 }\end{array}$} & 모태출자펀드 연간 투자 금액 \\
\cline { 2 - 2 } & 모태출자펀드 투자기업에 대한표 해외 후속투자유치 금액 \\
\cline { 2 - 2 } & 모태출자펀드 투자진척률 \\
\hline $\begin{array}{c}\text { 집중육성분야 모태출자펀드 } \\
\text { 투자금액 확대 }\end{array}$ & 모태출자펀드 주목적 투자 달성 비율 \\
\hline \multirow{4}{*}{$\begin{array}{c}\text { 민간 LP 참여 } \\
\text { 확대 }\end{array}$} & 회수시장 활성화: M\&A 건 수 및 IPO 건 수 \\
\cline { 2 - 2 } & 시장건전성 제고: 모태출자펀드 규약 및 법령위반 건 수 \\
\cline { 2 - 2 } & 민간 자금 출자 비중 \\
\hline \multirow{2}{*}{$\begin{array}{c}\text { 모태출자펀드 } \\
\text { 투자기업 } \\
\text { 성과 관리 }\end{array}$} & 피투자기업 일자리 증가 \\
\cline { 2 - 2 } & 피투자기업 매출액 증가 \\
\cline { 2 - 3 } & 모태출자펀드 투자기업 기업가치 증가 \\
\hline \multirow{2}{*}{ 모태펀드 } & 모태출자펀드 평가 수익배수(일반분야) \\
\cline { 2 - 2 } 수익률 제고 & 모태출자펀드 평가 수익배수(집중육성분야) \\
\hline
\end{tabular}

자료: 한국벤처투자(2019)

- 각 부처의 정책적 방향과 분야에 따라 다르게 구성되어 있는 18 개의 모태펀드 계정이 거의 동일한 기준으로 평가되고 있는 한계가 존재

- 각 계정의 특성을 담을 수 있는 항목은 모태출자펀드 주목적 투자 달성 비 율 밖에 없으며, 특히 문화계정의 특성을 나타낼 수 있는 성과지표는 구성 되어 있지 않음

- 중진계정의 경우에만 별도로 창업초기기업 투자규모확대(KPI 2)라는 성과 목표가 구성되어 있어 중진계정만의 특성화된 정책성과를 파악 중 
- 논리적인 흐름이나 성과의 특성에 따른 전략목표 체계설정이 아니라 각 전략 목표들이 독립적으로 모태펀드의 양적 성과만을 중심으로 이어져 궁극적인 목 표 수립정도를 파악하기 어려움

- 계획-실행-성과나, 투입-과정-결과와 같은 일반적인 논리흐름의 체계로 살 펴보면 거의 성과와 결과 지표 중심이고 일부 과정이나 계획에 대한 부분의 고려는 상대적으로 부족

- 펀드에서 일반적으로 활용되는 계량적인 지표 중심으로 이루어져 모태펀드 만의 정책적이고 각 계정의 이슈 관련 심층적인 내용이 반영되기 어려움 


\section{제3절 소결}

- 모태펀드는 수익성과 동시에 정책적 목표를 채워야하는 양면성을 지닌 금융 정책지원이며, 특히 문화계정은 펀드운용을 통해 문화산업을 활성화해야하는 정책적 목적이 더 뚜렷한 분야

- 펀드이지만 정부재원이 모태가 되기 때문에 정부가 추진하고자 하는 정책 방향이나 공공적 성격에 부합하는 역할을 수행해야함

- 그러한 취지에 맞춰서 정부는 모태펀드 문화계정에서 지속적으로 소외장르, 기획개발, 제작초기 등 투자위험성은 높지만 투입이 꼭 필요한 자금시장의 사각지대 영역에 지원을 강화

- 표준계약 의무화, 영화투자비율 제한, 임금체불제작자 투자금지, 프로젝트 의 경우 문화전문회사 의무화 등 정책적 목표를 위해 타계정 대비 더 복잡 하고 까다로운 제약이 많음

- 실제로, 모태펀드 문화계정은 2000년대 중반부터 산업고도화의 역할을 수행 하며 일부 콘텐츠산업의 발전에 생산적인 성과를 거둬옴

- 특히 영화산업은 산업이 성장되고 있던 시기에 집중 투자되어 신진 제작자 들이 양성되어 세계적인 제작자로 성장하는데 기여

- 기반이 약한 분야의 투자를 활성화시켜, 근본적으로 산업 성장의 기회를 제 공하고 제도의 뒷받침과 같은 산업의 체계성을 부여

- 하지만, 모태펀드 문화계정의 성과평가 지표는 이러한 정책기여에 대한 평가 보다는 다른 계정과 같은 일괄적 기준, 즉 수익성 중심으로 성과를 평가

- 현재 적용되고 있는 문화계정의 성과지표는 타계정과 구분 없이 일괄적으 로 적용되는 지표로, 투자금액확대, 수익률 제고 등 정책적 기여보다는 수 익성 중심의 양적평가 중심의 평가가 이뤄지고 있음 
- 의도적으로 정책적 방향을 위해 타 계정 대비 제약을 까다롭게 설정하고 운영방향도 투자위험성이 높은 취약모험 분야에 투자를 집중하고 있으면서 수익성을 중심으로 평가하는 것은 불합리

- 정리하면, 모태펀드 문화계정은 공공적 목적성이 뚜렷하고 그 목적성에 맞춰 정책을 수립하여 성과를 이뤄내고 있었으나, 수익성을 중심으로 성과를 파악 하여 산업의 정체성과 성과를 반영하지 못하는 평가를 진행 중

- 따라서 모태펀드 문화계정의 성과평가 지표를 구성할 때 수익성 외에 콘텐 츠 산업 활성화와 같은 공공적 기여가 포함된 지표구성과 평가가 이루어져 야 할 필요성이 있음 
모태펀드 문화계정 성과지표 개발 연구

제3장

사례 분석 및

전문가 자문회의 



\section{제1절 사례 분석}

\section{1. 사례분석 개요}

- 모태펀드 타계정 등 문화계정 외에 유사정책펀드와 콘텐츠산업 성과 지표의 사례를 분석하여 시사점을 도출하고, 해당 지표들 중에 문화계정에 활용할 수 있는 항목 및 지표는 벤치마킹

- 분석 대상: 모태펀드 타계정 및 유사 정책펀드 성과지표, 콘텐츠산업 관련 성과지표 등

- 방법: 지표의 일반현황과 세부 지표내용을 분석하여 세부적 특징과 지표의 구성 체계, 평가방법론 등을 분석

〈표 3-1〉사례분석 대상 및 주요 내용

\begin{tabular}{|c|c|c|}
\hline 분류 & 사례분석 대상 & 도출 내용 \\
\hline \multirow{3}{*}{$\begin{array}{l}\text { 유사 정책펀드 } \\
\text { 성과 지표 }\end{array}$} & 농식품모태펀드 성과 지표 & \multirow{3}{*}{$\begin{array}{c}\text { 유사계정들의 성과지표 비교, } \\
\text { 정책목표 반영방안 파악 벤치마킹 }\end{array}$} \\
\hline & 모태펀드 중진계정 성과 지표 & \\
\hline & 성장사다리펀드 성과 지표 & \\
\hline \multirow{2}{*}{$\begin{array}{l}\text { 콘텐츠산업 } \\
\text { 성과 지표 }\end{array}$} & 지역콘텐츠산업 경쟁력 지표 & \multirow{2}{*}{$\begin{array}{c}\text { 콘텐츠산업만이 특성 파악 방안, } \\
\text { 콘텐츠산업 반영 세부지표 벤치마킹 }\end{array}$} \\
\hline & 콘텐츠 경쟁력 지표 & \\
\hline
\end{tabular}




\section{2. 유사 정책펀드 및 정부 벤처캐피털 성과 지표 사례 분석}

\section{가. 농식품모태펀드 성과 지표7)}

1) 농식품모태펀드 및 성과지표 개요

- 농림수산식품 모태펀드(FAFF fund of funds)는 농어업경영체, 식품사업자 등 농림수산식품경영체에 대한 투자를 목적으로 설립된 농림수산식품투자조 합 또는 경영참여형사모집합투자기구에 출자하는 방식의 모태펀드

- 농림수산식품산업 관련 투자를 활성화하고, 농림수산식품산업의 경쟁력 강 화 및 규모 확장을 위한 정부 조성 투자펀드 시스템

- 농림축산식품부에서 2011년부터 농식품모태펀드의 운용성과를 모니터링하고 평가하여 피드백 할 수 있는 전략적 성과관리 체계를 도입

- 농식품모태펀드는 문화계정이나 중진계정 등과 달리 한국벤처투자가 아닌 농림축산식품부(농업정책보험금융원)에서 운용을 주관

- 이에 따라 자체적으로 농식품모태펀드 운용 성과지표를 도출하여 성과평가 를 진행

2) 지표 내용 및 시사점

- 성과지표를 사업운용 시기(단기, 중기, 장기)별로 구분하여 각 시기에 맞는 성 과지표를 적용

- 현재의 시기를 출자 중기로 파악하고 이에 맞춰서 사업계획 수립을 위한 기준 자료와 운용 성과지표로 활용

- 농식품모태펀드의 수명시기에 맞춰서 전략목표와 성과지표를 개선하고 개 발하여 시기별 필요 성과를 유도하고 평가의 효율성을 제고

7) 이동호·이호용·박준민·전병훈, 2018년 농식품투자모태조합 운영성과평가 보고서, 농업정책보험금융원 (2019)의 내용을 요약 
〈표 3-2〉 농식품모태펀드 성과 지표(2019년 기준)

\begin{tabular}{|c|c|c|c|c|}
\hline 관점 & CSF & KPI & 정의 & 평가방법 \\
\hline \multirow{2}{*}{ 재무 } & \multirow{2}{*}{$\begin{array}{l}\text { 모태조합 } \\
\text { 수익성 제고 }\end{array}$} & 투자자산가치 & $\begin{array}{l}\text { 매년 회계법인 자산평가보고서의 } \\
\text { 자산평가 }\end{array}$ & 계량 \\
\hline & & $\begin{array}{l}\text { 미출자자산 } \\
\text { 운용수익률 }\end{array}$ & 모태조합 미출자자산 운용성과 & 계량 \\
\hline \multirow{5}{*}{ 정책 } & \multirow[b]{2}{*}{$\begin{array}{l}\text { 농림수산식품분야 } \\
\text { 투자시장 조성 }\end{array}$} & 출자승수효과 & 지침 기준 이상으로 출자된 비율 & 계량 \\
\hline & & $\begin{array}{l}\text { 일정규모이하 } \\
\text { 농림수산식품 } \\
\text { 경영체 지원율 }\end{array}$ & $\begin{array}{l}10 \text { 인, } 10 \text { 억 이하 규모의 농림수산 } \\
\text { 식품 경영체 투자 실적 }\end{array}$ & 계량 \\
\hline & \multirow{3}{*}{$\begin{array}{l}\text { 농림수산식품분야 } \\
\text { 투자 지원 강화 }\end{array}$} & 매출액 증가율 & 투자기업의 매출액 증감 & 계량 \\
\hline & & 고용인원증가율 & $\begin{array}{l}\text { 투자 전·후 투자기업의 고용인원 } \\
\text { 증감 }\end{array}$ & 계량 \\
\hline & & 정책성과달성도 & $\begin{array}{l}\text { 특수목적분야 정책성과지표 달성도 } \\
\text { 평가 }\end{array}$ & 비계량 \\
\hline \multirow{5}{*}{ 프로세스 } & \multirow{4}{*}{$\begin{array}{l}\text { 펀드관리 } \\
\text { 적정성 제고 }\end{array}$} & $\begin{array}{l}\text { 사업계획수립의 } \\
\text { 적정성 }\end{array}$ & $\begin{array}{l}\text { 연간 농식품모태펀드 사업운영 계획 } \\
\text { 수립의 적정성 평가 }\end{array}$ & 비계량 \\
\hline & & $\begin{array}{l}\text { 자조합 선정의 } \\
\text { 적정성 }\end{array}$ & $\begin{array}{l}\text { 자조합 선정 및 결성을 위한 절차 및 } \\
\text { 기준 준수 노력을 평가 }\end{array}$ & 비계량 \\
\hline & & $\begin{array}{l}\text { 자조합 관리의 } \\
\text { 적정성 }\end{array}$ & $\begin{array}{l}\text { 자조합 관리를 위한 농금원의 사후 } \\
\text { 관리 노력 평가 }\end{array}$ & 비계량 \\
\hline & & 자조합 결성율 & 연간 사업계획 대비 자조합 결성율 & 계량 \\
\hline & $\begin{array}{l}\text { 펀드관리 질적 } \\
\text { 수준 제고 }\end{array}$ & $\begin{array}{l}\text { 농식품모태펀드 } \\
\text { 사업만족도 }\end{array}$ & $\begin{array}{l}\text { 농식품모태펀드 사업에 대한 자조합 } \\
\text { 및 출자운용사의 만족도 }\end{array}$ & 계량 \\
\hline \multirow[t]{2}{*}{ 인프라 } & \multirow{2}{*}{$\begin{array}{l}\text { 투자지원업무 } \\
\text { 강화 }\end{array}$} & 사업홍보 노력도 & $\begin{array}{l}\text { 출자사업설명회, 투자설명회(투자 } \\
\text { 로드쇼) 및 세미나 개최를 통한 } \\
\text { 농식품모태펀드 사업 홍보 노력 }\end{array}$ & 계량 \\
\hline & & 투자인프라 만족도 & $\begin{array}{l}\text { 전체 사업 만족도 대비 투자인프라 } \\
\text { 관련 만족도 평가 }\end{array}$ & 계량 \\
\hline
\end{tabular}

자료: 농업정책보험금융원(2019)

- 계량지표는 성과지표 중 계량 목표의 수립이 가능하거나, 사업계획 상 해당 성과지표의 계획 수치가 존재하는 지표에 대해서 설정

- 세부적으로는 투자자산 가치, 미출자자산 운용수익률, 출자승수효과, 일정 규모이하 농림수산식품 경영체 지원율, 매출액 증가율, 고용인원 증가율, 자조합 결성율, 농식품모태펀드 사업만족도, 사업홍보 노력도, 투자인프라 만족도 이렇게 10 개로 구성됨 
- 계량 성과지표의 평가는 각 성과지표별 목표 수치와 목표 대비 성과 달성 정도를 평가함

- 계량 성과지표와 관련하여 농업정책보험금융원의 해당년도 사업 추진 내역 및 설문조사와 관련 자료를 분석하여 해당 성과지표의 결과가 산출된 원인 을 분석함

- 계량 성과지표의 당해년도 평가 결과와 이전년도 평가들의 결과를 비교하 여 항목별 성과추세를 분석

- 비계량지표는 해당 지표의 성과를 계획, 실행, 성과 관점에서 정성적으로 평가

- 비계량지표는 4개이며 정책성과 달성도, 사업계획 수립의 적정성, 자조합 선정의 적정성, 자조합 관리의 적정성으로 이루어짐

- 비계량 평가는 계획, 실행, 성과 관점에서 평가하며, 실행 관점의 평가는 각 지표의 평가요소(3개)별로 평가

- 실행관점은 평가요소별 가중치에 따라 평가요소별로 점수를 산출

- 비계량 평가지표의 평가 방향은 적정한 계획 수립에 따라 해당 성과지표의 성과 달성을 위한 실행과제를 수행하고, 최종 성과를 점검하는 체계

- 현재는 초기 말에서 중기 초의 단계라 실행이 높게 측정되고 있지만 향후 성숙해감에 따라 점차 계획-성과 가중치를 높여나갈 예정

〈표 3-3〉비계량 평가 관점별 평가 단위

\begin{tabular}{c|c|c}
\hline 관점(가중치) & \multicolumn{1}{|c}{ 내용 } & 평가 단위 \\
\hline 계획(30\%) & $\begin{array}{l}\text { - 목적한 성과를 달성하기 위해 성과지표 추진을 위한 전반적 } \\
\text { 인 계획이 적정했는지 여부를 평가 }\end{array}$ & 성과지표 전체 \\
\hline \multirow{2}{*}{ 실행(40\%) } & $\begin{array}{l}\text { - 성과지표와 관련하여 세부적으로 수행(실행)한 업무가 성과 } \\
\text { 지표 목적 달성과 연관이 있으며 적정하게 효율적으로 수행 } \\
\text { 되었는지를 평가 }\end{array}$ & 성과지표의 평가요소별 \\
\hline 성과(30\%) & $\begin{array}{l}\text { 계획 및 실행 단계의 성과지표 추진을 통해 최몽 목적한 바태펀드 전체 성과제고에 기여하였는지를 } \\
\text { 평가 }\end{array}$ & 성과지표 전체 \\
\hline
\end{tabular}

자료: 농업정책보험금융원(2019) 


\section{나. 모태펀드 중진계정 성과 지표}

1) 중진계정 및 성과지표 개요

- 중진계정은 중소벤처기업부가 출자한 창업초기, 지방기업, 부품소재, M\&A등 에 투자하는 펀드

- 2019년 기준으로 중진 계정은 소셜임팩트 일반 및 루키, 민간제안, 스마트 공장, $\mathrm{M} \& \mathrm{~A}, \mathrm{LP}$ 유동화, 여성기업 등 6 개 분야에서 17 곳의 운용사가 자펀 드를 운영

- 중진계정의 성과지표는 한국벤처투자에서 운영하고 성과평가를 진행하고 있 는 다른 17 개의 계정과 마찬가지로 동일한 지표가 적용되고 있지만, 일부 중 진계정에만 적용되는 특화지표가 존재

2) 지표 내용 및 시사점

- 모태펀드 타 계정들과 성과목표 구성이 모두 같지만, 중소벤처기업부의 주된 정책방향인 중소벤처기업의 활성화의 취지에 맞춰서 '창업초기기업 투자규모 확대'라는 특화지표가 추가

- 창업초기기업 투자규모 확대에 해당되는 성과지표로는 창업초기펀드 결성 금액, 모태출자펀드 창업초기기업 금액, 엔젤 투자매칭펀드 투자기업에 대 한 후속투자금액 등

- 창업초기기업에 얼마나 투자되었는지에 대해 중점적으로 계량적 성과지표 들을 구성하여 정책목표 달성도를 확인

- 집중육성분야 모태출자펀드 투자금액 확대 성과목표에 대해서는 타계정의 모 태출자펀드 주목적 투자달성만 지표로 설정한 것과 달리 구체적으로 집중육성 분야에 대한 세부 지표들을 마련

- 집중육성분야 관련 모태출자펀드 결성금액, 연간 투자금액, 운용사 Pool확 대 노력 등 해당 분야에 대한 양적인 성과를 세부적으로 파악 
〈표 3-4〉2019년 모태펀드 성과 지표

\begin{tabular}{|c|c|}
\hline 성과목표 & 성과지표 \\
\hline \multirow{5}{*}{$\begin{array}{c}\text { 모태펀드 } \\
\text { 투자금액 확대 }\end{array}$} & 모태출자펀드 결성금액 \\
\hline & 모태출자펀드 연간 투자 금액 \\
\hline & 모태출자펀드 투자기업에 대한 해외 후속투자유치 금액 \\
\hline & 해외 VC네트워크 구축, 해외진출가능 기업 POOL구성 노력 등 \\
\hline & 신규예산 확보 노력 \\
\hline \multirow{4}{*}{$\begin{array}{l}\text { 창업초기기업 } \\
\text { 투자규모 확대 }\end{array}$} & 창업초기펀드 결성금액 \\
\hline & 모태출자펀드 창업초기기업 투자금액 \\
\hline & 엔젤 투자매칭펀드 투자기업에 대한 VC 등의 후속투자금액 \\
\hline & 창업초기기업 지원 기관 간 협력 노력, 창업초기기업대상 IR개최 등 \\
\hline \multirow{3}{*}{$\begin{array}{l}\text { 집중육성분야 } \\
\text { 모태출자펀드 } \\
\text { 투자금액 확대 }\end{array}$} & 집중육성분야 모태출자펀드 결성금액 \\
\hline & 집중육성분야 모태출자펀드 연간 투자금액 \\
\hline & 집중육성분야 운용사 POOL확대 노력 \\
\hline \multirow{5}{*}{ 민간 LP 참여 확대 } & 민간출자 금액과 신규 민간출자자 수 \\
\hline & 민간출자 유치 노력 \\
\hline & 회수시장 활성화 \\
\hline & 민간제안펀드 결성금액 \\
\hline & 시장건전성 제고 \\
\hline \multirow{6}{*}{$\begin{array}{c}\text { 모태출자펀드 } \\
\text { 투자기업 성과 관리 }\end{array}$} & 피투자기업 일자리 증가 \\
\hline & 피투자기업 매출액 증가 \\
\hline & 피투자기업가치증대 노력 \\
\hline & 시가총액 1조원 기업(상장) \\
\hline & 시가총액 1조원 기업(비상장) \\
\hline & 모태출자펀드 투자기업 기업가치 증가 \\
\hline \multirow{4}{*}{$\begin{array}{c}\text { 모태펀드 } \\
\text { 수익률 제고 }\end{array}$} & 모태출자펀드 평가 수익배수(일반분야) \\
\hline & 모태출자펀드 평가 수익배수(집중육성분야) \\
\hline & 배분금액 \\
\hline & 수익률 제고를 위한 노력 \\
\hline
\end{tabular}

자료: 한국벤처투자(2019) 
- 모든 지표들이 계량지표로 이루어졌던 것과 다르게 중기계정 지표의 경우에는 노력도와 같은 정성적 지표를 보완지표로 활용

- 네트워크 및 Pool 구성 노력도, 창업초기기업 기관 간 협력 노력, 민간출자 유치 노력, 수익률 제고를 위한 노력 등과 같이 성과목표를 입체적으로 살 펴보기 위해 질적 지표를 활용

\section{다. 성장사다리펀드 성과지표}

1) 성장사다리펀드 및 성과지표 개요

- 성장사다리펀드는 유망한 벤처중소기업 및 성장자금이 필요한 중견기업을 발 굴하여 창업과 성장에 필요한 자금을 지원하기 위해 만든 펀드로 3 개의 출자 기관(은행청년창업재단, $\mathrm{IBK}, \mathrm{KDB})$ 이 1 조 8,500 억 원을 출자

- 시장실패 영역을 중심으로 선도적 장기 모험자본 역할을 수행함과 동시에 전문 운용기관을 선정하여 시장 친화적인 방법으로 운영하여 정책성과 수 익성의 조화를 도모

- 통합펀드는 정책목적에 부합하는 하위펀드를 선정·투자하고, 하위펀드 운 용사는 개별 기업에 대한 투자를 집행하여 펀드를 운용

- 투자자 간 리스크 분리 구조를 통하여 기존 벤처캐피탈 둥이 지원하지 못했 던 영역에 정책자금이 선도적 모험자본의 역할 수행 및 수익성에 기반한 포 트폴리오 운용을 통하여 장기 민간자금도 쉽게 유입될 수 있는 기반을 마련

- 성장사다리펀드와 모태펀드는 재원(은행자본 vs. 국가재정) 성격이 전혀 다르 며, 모험자본으로서 서로 다른 역할을 수행 중

- 모태펀드는 창업, 엔젤 분야에 집중하는 반면, 사다리펀드는 생태계 외 민 간자금 유입 및 기업의 체계적 성장(창업 $\rightarrow$ 중소 $\rightarrow$ 중견)에 초점을 맞추고 있어 상호 경쟁·보완을 통한 시너지 창출이 가능 
〈표 3-5〉 성장사다리펀드와 모태펀드 비교

\begin{tabular}{|c|c|c|c|}
\hline & 구분 & 성장사다리펀드 & 모태펀드 \\
\hline & 법적형태 & $\begin{array}{c}\text { 전문투자형사모집합투자기구 } \\
\text { (투자신탁) }\end{array}$ & 중소기업투자모태조합 \\
\hline & 설립근거 & 자본시장법 제9조 제19항 & 벤처기업법 제4조의2 \\
\hline & 소관부처 & 금융위원회 & 중소기업청 \\
\hline & 출자자 & $\begin{array}{c}\text { 정책은행 등 } \\
\text { (KDB, IBK, 은행권청년창업재단) }\end{array}$ & $\begin{array}{c}\text { 재정 } \\
\text { (중기청, 문체부, 특허청, 영진위, } \\
\text { 과기정통부, 고용부, 보건부 등) }\end{array}$ \\
\hline & 후자대상 & $\begin{array}{c}\text { 제한없음 } \\
\text { (중소·중견·대기업 모두 가능) }\end{array}$ & 중소·벤처기업 \\
\hline & 드투자방식 & 투자, 대출 및 지급보증 등 & 투자 위주 \\
\hline & 존속기간 & 2013 2033년(20년간) & 2005 2035년(30년간) \\
\hline \multirow{3}{*}{$\begin{array}{l}\text { 운영 } \\
\text { 기관 }\end{array}$} & 법적형태 & $\begin{array}{l}\text { 전문사모집합투자업자 } \\
\text { (민간 자산운용사) }\end{array}$ & $\begin{array}{c}\text { 창업투자회사 } \\
\text { (기타 공공기관) }\end{array}$ \\
\hline & 주요주주 & $\begin{array}{c}\text { 거래소, 예탁원, 금투협회, 증권금융, } \\
\mathrm{KDB}, \mathrm{IBK} \text {, 청년창업재단 }\end{array}$ & 중소기업진흥공단 \\
\hline & 감독기관 & 금융감독원 & 중소벤처기업부 \\
\hline
\end{tabular}

자료: 한국성장금융투자운용, 한국벤처투자

\section{2) 지표 내용 및 시사점}

- 성장사다리펀드는 성장사다리펀드의 객관적인 운영성과를 평가하기 위한 성 과평가(활동) 지표를 구성하여 매년 평가를 진행

- 전략목표로 펀드운용선진화, 창업벤처자금생태계 선순환 구조 확립, 피투자 기업 성장이라는 세 가지 목표에 선택과 집중

- 성과목표에서는 계획(운용계획·출자계획의 충실성 등), 실행(선정절차 및 기 준의 공정성 등), 성과(목표수익률), 효과(투자선순환유도, 피투자기업 성장 등)에 관련한 지표들이 세부적으로 구성됨

- 특히, 27 개나 되는 성과지표를 전략목표와 성과목표에 맞춰서 촘촘하게 수 립하여 몇몇 대표 지표를 통해 일반화되는 왜곡 극복 시도

- 측정 가능한 계량지표와 노력도와 같은 비계량 성과지표를 결합

- 각 성과목표에서 목표수익률 달성, 매출액 증가율, 부채비율, 고용 증가율 과 같은 계량지표와 함께 다양한 제고 및 활성화 노력도 등의 비계량 지표 를 적절히 활용해 측정이 안 되는 성과들을 보완 
〈표 3-6〉 성장사다리펀드 성과지표(2019년 기준)

\begin{tabular}{|c|c|c|}
\hline 전략목표 & 성과목표 & 성과지표(KPI) \\
\hline \multirow{11}{*}{$\begin{array}{c}\text { 성장 } \\
\text { 사다리 } \\
\text { 펀드 운용의 } \\
\text { 선진화 }\end{array}$} & $\begin{array}{l}\text { 성장사다리펀드운용계획의 } \\
\text { 충실성 제고 }\end{array}$ & 성장사다리펀드 운용계획 수립의 충실성 제고 노력 \\
\hline & 하위펀드 출자계획의 충실성 제고 & 하위펀드 출자계획 수립의 충실성 제고 노력 \\
\hline & 성장사다리펀드운용구조의 고도화 & 성장사다리펀드 운용구조의 고도화 노력 \\
\hline & $\begin{array}{c}\text { 하위펀드 선정 절차 및 기준의 } \\
\text { 공정성 제고 }\end{array}$ & 하위펀드 선정 절차 및 기준의 공정성 제고 노력 \\
\hline & \multirow{5}{*}{$\begin{array}{l}\text { 하위펀드 결성 및 운용, } \\
\text { 사후관리의 고도화 }\end{array}$} & $\begin{array}{l}\text { 하위펀드 운용기관(GP)의 하위 펀드 운용구조 } \\
\text { 고도화노력 }\end{array}$ \\
\hline & & 하위펀드의 계획 기간 내 결성 비율 \\
\hline & & 하위펀드의 출자계획 대비 실제 결성액 달성률 \\
\hline & & 하위펀드의 투자진척률 \\
\hline & & 하위펀드 운용기관(GP) Survey 점수 \\
\hline & \multirow{2}{*}{ 성장사다리펀드 수익성 제고 } & 성장사다리펀드 투자자산 목표수익률 달성 \\
\hline & & 미투자자산 자금관리 목표수익률 달성 \\
\hline \multirow{12}{*}{$\begin{array}{c}\text { 창업벤처 } \\
\text { 자금 생태계 } \\
\text { 선순환구조 } \\
\text { 확립 }\end{array}$} & \multirow{2}{*}{$\begin{array}{c}\text { 모험자본시장에 대한 } \\
\text { 성장사다리펀드 기여도 확대 }\end{array}$} & $\begin{array}{l}\text { 성장사다리펀드의 모험자본투자패러다임 } \\
\text { 선진화 노력 }\end{array}$ \\
\hline & & 하위펀드 조성과 관련한 관행 개선 노력 \\
\hline & \multirow{3}{*}{$\begin{array}{l}\text { 창업벤처기업의 원활한 자금 } \\
\text { 공급을 위한 투자 활성화 }\end{array}$} & 성장사다리펀드의 창업벤처지원 활성화 노력 \\
\hline & & 창업벤처지원펀드의 주목적투자 이행비율 \\
\hline & & 창업벤처지원펀드 민간출자 레버리지 달성률 \\
\hline & \multirow{3}{*}{$\begin{array}{c}\text { 성장과정에 있는 기업의 원활한 } \\
\text { 자금공급을 위한 투자활성화 }\end{array}$} & 성장사다리펀드의 성장지원 활성화 노력 \\
\hline & & 성장지원펀드의 주목적투자 이행비율 \\
\hline & & 성장지원펀드 민간출자 레버리지 달성률 \\
\hline & \multirow{3}{*}{$\begin{array}{c}\text { 회수재기지원시장 활성화를 통한 } \\
\text { 모험자본투자의 선순환 유도 }\end{array}$} & 성장사다리펀드의 회수재기지원 활성화 노력 \\
\hline & & 회수재기지원펀드의 주목적투자 이행비율 \\
\hline & & 회수재기지원펀드 민간출자 레버리지 달성률 \\
\hline & $\begin{array}{c}\text { 투자 선순환구조 확립을 위한 } \\
\text { 네트워킹 활성화 }\end{array}$ & 투자 선순환 구조 확립을 위한 네트워킹 활성화 노력 \\
\hline \multirow{4}{*}{$\begin{array}{l}\text { 피투자기업의 } \\
\quad \text { 성장 }\end{array}$} & 피투자기업의 성장성 향상 & 피투자기업 매출액 증가율 \\
\hline & 피투자기업의 안정성 향상 & 피투자기업 부채비율 \\
\hline & 피투자기업의 고용증대 & 피투자기업 고용 증가율 \\
\hline & 피투자기업 지원유효성 증대 & 피투자기업 만족도조사 점수 \\
\hline
\end{tabular}

자료: 한국성장금융투자운용(2019) 


\section{3. 콘텐츠산업 관련 성과 지표 사례 분석}

\section{가. 지역 콘텐츠산업 경쟁력 지표8)}

1) 지역 콘텐츠산업 경쟁력 지표 개요

- 지역 콘텐츠산업 경쟁력 지표는 지역단위 콘텐츠산업을 파악할 수 있는 지표 를 개발하여 지역 콘텐츠산업에 대한 지속적인 정보 생산체계를 구축하고자하 는 목적으로 개발

- 지역 단위의 콘텐츠산업 관련 중요성을 파악하고 해당지점에서의 정보 수 준을 진단하여, 지역 콘텐츠산업 경쟁력지표의 개발 당위성을 확보

- 지역 콘텐츠산업 경쟁력 모델을 기준으로 구성 항목들을 구성하고, 기존 자 료를 활용하여 지표의 활용성 및 실제화를 강화

- 시장과 정책정보를 구축하는 체계를 만들어 콘텐츠산업 정책성과를 높이는 데 초점을 두고 있음

- 지역 콘텐츠산업 경쟁력 지표 개발은 $\mathrm{OECD(2008)가} \mathrm{권장한} 10$ 단계의 지표 구성 절차에 따라 이론적 체계를 개발

- 국내외 주요 지표 검토체계를 바탕으로 8가지 핵심 지표 검토 요소 도출

2) 지표 내용 및 시사점

- 경쟁력 평가에 초점을 맞춰서 지역 경쟁력, 산업 경쟁력, 콘텐츠 경쟁력 등 다양한 차원에서의 분석을 통해 지표를 구성

- 지역 경쟁력, 산업 경쟁력, 콘텐츠 경쟁력이 겹치는 교집합 부분을 중요하 게 취급하면서도 지역 콘텐츠산업 경쟁력 관련 측정은 외부적인 요소를 광 범위하게 포함한 범위를 다룸

- 특히, 콘텐츠산업의 특수성을 고려하여 콘텐츠산업 관련 산업 구조 요소, 행위 요소, 성과 요소 등을 종합적으로 파악하고 측정하는 지표 개발

8) 이용관·박찬욱·이성민·한정임·이수현, 지역 콘텐츠산업 경쟁력 지표 개발 기초연구, 한국문화관광연구원 (2018)의 내용을 요약 
- 능력이나 자원을 공유 가능한 지역에서의 연관 산업 활동과 지역으로 유입 되는 인력 및 기업의 활동까지 포괄

- 지표를 3 가지 핵심영역(자원 경쟁력, 활동 경쟁력, 성과 경쟁력), 4 가지 핵심 요소(구조, 행위, 성과, 지역이 보유한 자원), 5가지 핵심 지표(자원 지표, 성과 지표, 산업 지표, 환경 지표, 정책 지표)로 체계성을 갖추어 구성

〈표 3-7〉 지역 콘텐츠산업 경쟁력 지표

\begin{tabular}{|c|c|c|c|}
\hline 핵심지표 & 중분류 & 평가항목 & 항목 정의 \\
\hline \multirow{8}{*}{ 자원지표 } & \multirow{3}{*}{ 인적자원 } & 예비인력 & 해당 지역 콘텐츠산업의 예비인력 규모 \\
\hline & & 창조인력 & 해당 지역의 창조인력 규모 \\
\hline & & 노동생산성 & 해당 지역 산업의 노동의 효율성 \\
\hline & \multirow{3}{*}{ 유형자원 } & 자본형성 & 해당 지역 투자 활동 정도 \\
\hline & & 제작인프라 & 해당 지역 제작시설의 접근성 및 이용 가능성 \\
\hline & & 자본생산성 & 해당 지역 산업의 자본의 효율성 \\
\hline & \multirow[b]{2}{*}{ 무형자원 } & 지식재산권보유 & 해당 지역의 지식재산권 보유 정도 \\
\hline & & 문화자원 & $\begin{array}{l}\text { 해당 지역 콘텐츠산업의 문화적·역사적·전통적 상호작용 } \\
\text { 기회 정도 }\end{array}$ \\
\hline \multirow{9}{*}{ 산업지표 } & \multirow{5}{*}{ 산업구조 } & 창업-폐업률 & 해당 지역 콘텐츠산업의 시장 진입 여건과 역동성 \\
\hline & & 벤처기업률 & 해당 지역 콘텐츠산업의 성장성과 사업화 가능성 \\
\hline & & 기업생존률 & 해당 지역 콘텐츠산업의 지속 가능성 \\
\hline & & 특화도 & 해당 지역 콘텐츠산업의 상대적 규모와 집적정도 \\
\hline & & 클러스터정도 & 해당 지역 콘텐츠산업의 전문화와 공간적 집중, 네트워킹 수준 \\
\hline & \multirow{4}{*}{ 산업활동 } & 연구개발 & 해당 지역 콘텐츠기업의 기업 혁신 활동 \\
\hline & & 신규사업진출 & 해당 지역 콘텐츠기업의 사업 확장 활동 \\
\hline & & 전략적제휴 & 해당 지역 콘텐츠기업의 네트워크 구축 활동 \\
\hline & & 지식재산권활용 & 해당 지역 콘텐츠기업의 지식재산권 활용 \\
\hline \multirow{5}{*}{$\begin{array}{l}\text { 환경 } \\
\text { 지표 }\end{array}$} & \multirow{2}{*}{ 연관산업구조 } & 특화도 & 해당 지역 콘텐츠 연관산업의 상대적 규모와 집적 정도 \\
\hline & & 성장성 & 해당 지역 콘텐츠 연관산업의 상대적 성장성 \\
\hline & \multirow{3}{*}{ 연관산업활동 } & 콘텐츠산업진출 & 해당 지역 연관산업의 콘텐츠 영역 확장 정도 \\
\hline & & $\begin{array}{l}\text { 콘텐츠관련 } \\
\text { 외부위탁 }\end{array}$ & 해당 지역 연관산업의 콘텐츠분야 연계 정도 \\
\hline & & $\begin{array}{l}\text { 콘텐츠관련 } \\
\text { 전략적 제휴 }\end{array}$ & 해당 지역 연관산업의 콘텐츠분야 협력 정도 \\
\hline
\end{tabular}




\begin{tabular}{|c|c|c|c|}
\hline 핵심지표 & 중분류 & 평가항목 & 항목 정의 \\
\hline & \multirow{4}{*}{ 정주여건 } & 문화향유요건 & 해당 지역의 문화향유권을 보장하는 시설의 접근성 \\
\hline & & 거주여건 & 해당 지역의 생활비용 수준 \\
\hline & & 노동여건 & 해당 지역의 노동조건 \\
\hline & & 교통여건 & 해당 지역의 인적·물적 자원의 접근성 \\
\hline & \multirow{4}{*}{ 정주여건개선 } & 문화향유개선 & 해당 지역의 문화향유권을 보장하는 시설의 접근성 개선 \\
\hline & & 거주여건개선 & 해당 지역의 생활비용 수준 개선 \\
\hline & & 노동여건개선 & 해당 지역의 노동조건 개선 \\
\hline & & 교통여건개선 & 해당 지역의 인적·물적 자원의 접근성 개선 \\
\hline \multirow{8}{*}{$\begin{array}{l}\text { 정책 } \\
\text { 지표 }\end{array}$} & \multirow{4}{*}{ 정책구조 } & 정책기획 & 해당 지역 자치단체의 정책기획 역량 \\
\hline & & 산업진흥조직 & 해당 지역 자치단체의 진흥사업 실행 역량 \\
\hline & & 시설기반규모 & 해당 지역 콘텐츠산업 인프라 지원 규모 \\
\hline & & 재원투입규모 & 해당 지역 콘텐츠산업 예산 투입 규모 \\
\hline & \multirow{4}{*}{ 정책활동 } & 정책기획활동 & 해당 지역 자치단체의 정책 기획 활동 \\
\hline & & 산업진흥활동 & 해당 지역 자치단체의 산업 진흥 관련 사업추진 활동 \\
\hline & & 시설구축활동 & 해당 지역 콘텐츠 관련 인프라 구축 활동 \\
\hline & & 재원조달활동 & 해당 지역 콘텐츠산업 진흥 관련 예산 조달 활동 \\
\hline \multirow{6}{*}{$\begin{array}{l}\text { 성과 } \\
\text { 지표 }\end{array}$} & \multirow{2}{*}{ 기업성과 } & 성장성 & 해당 지역 콘텐츠기업의 성장 가능성 \\
\hline & & 수익성 & 해당 지역 콘텐츠기업의 경영성과 \\
\hline & \multirow{2}{*}{ 산업성과 } & 산업성장률 & 해당 지역 콘텐츠산업의 부가가치 창출 성과 \\
\hline & & 고용증가율 & 해당 지역 콘텐츠산업의 일자리 창출 성과 \\
\hline & \multirow{2}{*}{ 지역성과 } & 인력유입 & 해당 지역으로의 콘텐츠 전공자 및 경력자 유입 정도 \\
\hline & & 기업유치 & 해당 지역의 콘텐츠기업 유치정도 \\
\hline
\end{tabular}

자료: 한국문화관광연구원(2018)

\section{나. 콘텐츠 경쟁력 평가9)}

\section{1) 콘텐츠 경쟁력 평가 개요}

- 콘텐츠 경쟁력 평가는 국내 방송콘텐츠 산업의 경쟁력 제고하기 위해서 방송 사업자의 콘텐츠 경쟁력 평가 지표를 개발한 평가

- 국내 방송콘텐츠 산업, 정부의 지원정책 및 평가제도의 현황과 문제점을 분석 하고 콘텐츠 분야에 특화된 방송사업자의 경쟁력 평가제도 도입의 필요성 도출

9) 황준호·임희수·정인숙·김성철, 콘텐츠 경쟁력 평가방안 연구, 방송통신위원회(2011)에서 요약 
- 콘텐츠 경쟁력 평가를 통해 방송사업자 간 경쟁이 촉진됨으로써 국내 방송 콘텐츠산업의 활성화와 사업자의 경쟁력을 전반적으로 제고하는 것을 목적

\section{2) 지표 내용 및 시사점}

- 콘텐츠 경쟁력 평가 방안 연구의 평가 방안 개발은 콘텐츠 산업의 가치사슬 구조(기획, 제작, 유통)를 기본으로 각 과정에 대한 세부 평가항목을 제시하는 방식의 논리구조를 취함

- 콘텐츠의 기본적인 내용과 형식을 구성하는 기획단계의 핵심가치는 창의성, 콘텐츠를 구체화하는 제작단계의 핵심가치는 전문성, 그리고 생산된 콘텐츠 를 방송사나 소비자들에게 공급하는 유통단계의 핵심가치는 효율성으로 정의

- 각 과정에서 필요로 하는 input 요소(인적자원, 물적자원)지표와 경제적 성과 와 사회적인 성과로 구분하는 output 성과지표로 세분화

- 콘텐츠 경쟁력 개념의 구성요인을 자원(input) 경쟁력(인적자원 경쟁력, 물 적자원 경쟁력)과 프로세스(process) 경쟁력(기획 경쟁력, 제작 경쟁력, 유 통 경쟁력), 그리고 성과(output) 경쟁력(경제적 성과 경쟁력, 사회적 성과 경쟁력)으로 정의

- 각각의 구성요인을 경쟁력에 대한 세부 평가항목을 제시하는 방식으로 지 표를 구성

〈표 3-8〉 프로세스 경쟁력 평가항목

\begin{tabular}{|c|c|c|}
\hline 경쟁력 요인 & 평가항목 & 항목 정의 \\
\hline \multirow{7}{*}{$\begin{array}{c}\text { 기획 } \\
\text { 경쟁력 }\end{array}$} & 기획 아이디어 생산방식 & $\begin{array}{l}\text { 기획 아이디어 사내외 공모(pitching) 시스템 운영여부, } \\
\text { 기획 아이디어 데이터베이스 운영 및 관리 여부 }\end{array}$ \\
\hline & 기획 아이디어 생산성 & 하위펀드 출자계획 수립의 충실성 제고 노력 \\
\hline & $\begin{array}{c}\text { 성장사다리펀드운용구조의 } \\
\text { 고도화 }\end{array}$ & 성장사다리펀드 운용구조의 고도화 노력 \\
\hline & 신규콘텐츠개발 & 하위펀드 선정 절차 및 기준의 공정성 제고 노력 \\
\hline & 투자유치 & 콘텐츠 제작, 유통에 필요한 투자자금 유치능력 \\
\hline & 수익모델 & 합리적이고 실행가능한 콘텐츠 수익모델의 수립여부 \\
\hline & 예산관리 & 적정하고 효율적인 예산수립 및 관리 방식 존재여부 \\
\hline
\end{tabular}




\begin{tabular}{|c|c|c|}
\hline 경쟁력 요인 & 평가항목 & 항목 정의 \\
\hline & 제작 단계 효율적 관리 & $\begin{array}{l}\text { 사전제작 } \rightarrow \text { 제작 } \rightarrow \text { 사후제작 단계별 특성에 따른 콘텐츠 } \\
\text { 제작의 효율적 관리를 위한 매뉴얼 수립여부 }\end{array}$ \\
\hline & 인력 관리 & 사내외 인력 캐스팅 및 배치의 효율적 관리 \\
\hline & 방송편성계획 & 시청률 및 수익성을 극대화할 수 있는 방송편성계획 수립 여부 \\
\hline & 공동기획 & 국내 및 국제 제작사와의 공동기획 건수 \\
\hline \multirow{9}{*}{$\begin{array}{l}\text { 제작 } \\
\text { 경쟁력 }\end{array}$} & 제작 생산성 & 연간 콘텐츠 총 제작 편수 \\
\hline & 자체제작 & 연간 전체 제작 콘텐츠 대비 자체제작 콘텐츠 비율 \\
\hline & 공동제작 & 연간 전체 제작 콘텐츠 대비 국내외 공동제작 콘텐츠 비율 \\
\hline & HD제작 & 연간 전체 제작 콘텐츠 대비 HD콘텐츠 비율 \\
\hline & 융합콘텐츠제작 & $\begin{array}{l}\text { 연간 전체 제작 콘텐츠 대비 융합형 콘텐츠(양방향, 3D, } \\
\text { 증제작 사례 건수 }\end{array}$ \\
\hline & 콘텐츠 재활용 & $\begin{array}{l}\text { 기존 콘텐츠를 활용한 2차 가공 콘텐츠(속편, 스핀오프 등) } \\
\text { 제작 사례 건수 }\end{array}$ \\
\hline & 제작 효율성 & 평균 제작기간, 제작기간 단위 평균 제작비용 \\
\hline & 편집 효율성 & 평균 편집기간, 평균 편집기간 단위 평균 편집비용 \\
\hline & 품질관리 & 품질관리 매뉴얼 구비 여부, 품질관리 공인기법 적용(인증) 여부 \\
\hline \multirow{8}{*}{$\begin{array}{l}\text { 유통 } \\
\text { 경쟁력 }\end{array}$} & 마케팅 & 제작완료 후 1차 유통(방영) 때까지 소요되는 평균 기간 \\
\hline & 방송 유통경로확보 & 콘텐츠가 유통되는 방송 플랫폼 수 \\
\hline & 유통망 다각화 & $\begin{array}{l}\text { 방송 플랫폼 외 콘텐츠가 유통되는 윈도우 수(모바일, 온라인, } \\
\text { VOD, DVD 등) }\end{array}$ \\
\hline & 광고 및 홍보 & $\begin{array}{l}\text { 광고 및 홍보비 대비 콘텐츠 평균 수익성, 제작비 대비 광고 및 } \\
\text { 홍보비 비중 }\end{array}$ \\
\hline & 글로벌 유통 & $\begin{array}{l}\text { 글로벌 시장 진출 역량(견본시 참여, 해외 계약 건수 등), } \\
\text { 전체 콘텐츠 중 글로벌 시장에서 유통되는 콘텐츠 비중 }\end{array}$ \\
\hline & 콘텐츠 유통 평균 수명 & 관련 시장에서 콘텐츠 유통이 지속되는 평균 기간 \\
\hline & 투자비 회수 & 콘텐츠 기획, 제작, 유통에 투자된 비용의 평균 회수 기간 \\
\hline & 고객관리 & 콘텐츠에 대한 시청자 및 이용자의 피드백 관리 역량 \\
\hline
\end{tabular}

자료: 정보통신정책연구원(2011) 


\section{제2절 전문가 의견 조사}

\section{1. 자문회의 개요}

- 실질적인 지표 개발을 위해 전문가 및 업계 관계자 자문회의를 진행하여 모태 펀드 문화계정의 현황과 문제점을 파악하고 지표개선 방안을 마련

〈표 3-9〉 자문위원 명단

\begin{tabular}{|c|c|}
\hline 구분 & 인터뷰 대상 \\
\hline 모태펀드 운영기관 & $\begin{array}{l}\text { - A(a기관 팀장) } \\
\text { - B(a기관 대리 })\end{array}$ \\
\hline $\begin{array}{c}\text { 문화계정 출자조합 } \\
\text { 운용사 }\end{array}$ & $\begin{array}{l}\text { - } \mathrm{C}(\mathrm{VC} \text { b사 이사 }) \\
\text { - } \mathrm{D}(\mathrm{VC} \text { c사 상무이사 }) \\
\text { - } \mathrm{E}(\mathrm{VC} \text { d사 상무이사 })\end{array}$ \\
\hline 투자사 및 투자기관(LP) & $\begin{array}{l}\text { - } \mathrm{F} \text { (e은행 투자부서 팀장) } \\
\text { - G(f은행 투자부서 팀장) }\end{array}$ \\
\hline 학계/연구계 & $\begin{array}{l}\text { - H(g연구원 원장 }) \\
\text { - I(h대 교수) } \\
\text { - J(i대 교수) }\end{array}$ \\
\hline
\end{tabular}

- 기간: 2020년 5월 1일 2020년 7월 30일

- 자문회의 차수: 8차에 걸쳐서 전문가 자문회의 진행

- 대상: 모태펀드 운영기관(문화계정 담당자, 모태펀드 성과지표 담당자), 문 화계정 출자조합 운용사(문화계정 운용 유경험 담당자), 학계 및 연구계 전 문가(문화계정 성과지표 개발 유경험자, 성과평가 유경험자, 문화계정 관련 연구 유경험자)

- 방법: 구조화된 질문지 또는 회의 안건 제시를 통한 토론 진행, 온라인 원격 회의와 현장회의 병행 
- 자문회의 주요 내용: 모태펀드 관련 주요 이슈와 트렌드, 문화계정의 특성, 문화계정 성과 평가 시의 시행착오, 문화계정의 정책적 한계와 개선점, 문 화계정 기존 성과지표의 문제점, 문화계정 출자조합의 특성과 구성 등 논의

\section{2. 전문가 및 업계 관계자 자문회의 결과}

\section{가. 프로젝트 투자(PF)가 주도하는 특성 고려 필요}

- 최근 들어서야 기업투자가 늘어나고는 있지만 문화계정은 타계정과 다르게 프 로젝트 중심(Project Finance)으로 투자가 이루어지는 경향 존재

- 콘텐츠의 정보비대칭성의 문제로 인해 상대적으로 빠져나오기 편하고 투자 회수

- 특히 명성있고 규모가 큰 배급사가 확보되어 가능성이 높은 주기가 짧은 프로젝트성 분야에 투자가 몰림

- 콘텐츠는 제작 시, 최적의 인력구성과 창작 시너지를 창출하기 위해 프로젝 트 별로 제작인력을 구성하고 관행상 기간에 한정된 프리랜서가 다수 포진 되어 있는 구조로 이루어짐

"문화계정을 시작할 당시만 해도 대기업 외에는 콘텐츠 산업에서 투자할 만 한 기업이 존재하지 않았다. 즉, 기업에 지분투자요건을 충당할 수 있을 만한 대상자체가 거의 없었던 것이다. 문화계정에서 프로젝트 투자 시, 문 화산업전문회사라는 페이퍼 컴퍼니를 설립해야하는 조항을 만든 것도 대 부분 프로젝트로 진행되다보니 회계 절차와 같은 투명성을 확보하기 위해 서였다. 최근 들어 지분투자가 늘어나고 있는 것은 그 만큼 산업이 성장했 다는 것을 의미하는 것이기도 하다. 하지만 여전히 문화계정에서는 기업지 분 투자보다 프로젝트 투자의 비중이 높다”

- 콘텐츠 제작관련 투자는 제작사의 여러 작품 결과를 보고 투자·회수하기보 다는 배급사나 각 작품의 구성원의 명성 등과 같은 프로젝트 외부환경을 고 려하여 작품에 투자하여 상대적으로 손실가능성이 낮음 
- 투자자 입장에서도 제작사의 역량만을 믿고 여러 작품에 위험을 감수하기 보다는 각 작품을 배급사나 제작자, 배우 등의 명성에 따라 선택하여 투자 하는 것이 투자의 안정성에 있어서 더 유리한 것으로 인식

"프로젝트성 투자는 투자할 대상이 많고, 단기로 진행되어 상대적으로 흥행 예측이 가능해 기대수익을 달성하기에 수월한 장점을 지닌다. 하지만 큰 흥행을 이루더라도 수익배수가 2배 내외에 불가하다는 한계가 있다. 예를 들어 1,000만 관객을 동원해 대박을 터뜨렸던 '베테랑'의 수익배수도 2.38 2.46배(2016년 회수기준) 정도에 불과하다. 반면, 기업 지분투자는 대상이 제한적이지만 대박이 날 경우 많게는 10배 이상의 큰 수익배수를 얻을 수 있다. 이러한 면에서 프로젝트 투자는 수익률의 한계성이 뚜렷하다.”

- 모태펀드 문화계정의 투자 대상의 과반수이상이 프로젝트 투자임에도 불구 하고 관련 지표가 대부분 기업 중심으로 이루어짐

- 기업의 성장성이나 일자리 증가, 수익성 관련 지표들은 대부분 프로젝트성 투자를 고려하지 못하고 기업중심의 투자에 초점을 맞춰 만든 지표이기 때 문에 문화계정을 모두 평가하기에 한계가 있음

\section{나. 콘텐츠산업 분야 간 큰 격차를 극복할 수 있는 지표 구성 필요}

- 문화계정의 영역이 워낙 넓고 복잡하여 산업의 수명주기 상 성장기를 거쳐 성 숙기를 향하고 있는 영역과 도입기나 초기 성장기 단계의 취약한 시장 간의 간극이 매우 커 일괄적으로 평가하기 어려움 존재

- 산업이 성숙한 분야는 투자와 운용프로세스에 있어서 미성숙한 분야와는 확연히 다른 성격을 띠고 있음

- 예를 들어 산업이 발전한 분야는 유통사 역할이 크게 자리 잡아 이들이 조 율하고 제작자체를 성립시키는, 즉 유통의 관계성에 의해 투자가 주도되는 경우가 많으며 그만큼 실패 리스크를 줄일 수 있음

- 반면, 취약분야의 투자는 보장된 유통사나 제작사가 부족하여 사실상 벤처 캐피탈에서도 수익을 얻기 어려운 구조로 인식되고 있음 
“영화 프로젝트 투자 같은 경우 산업자체가 고도화되어 메이저 유통사들이 먼저 제작자와 배우, 기획, 제작 등을 미리 다 세팅한 후 투자를 모집하여 이미 어느 정도 리스크를 제거한 상태에서 투자가 이루어지는 경우도 많 다. 반면 애니메이션 프로젝트 투자의 경우에는 아직 전체 제작의 세팅을 주도할 수 있는 유통사가 없거나 부족하다고 할 수 있다. 시장의 불확실성 이 매우 큰 편이라 GP들의 경우 애니메이션 프로젝트에 대한 자펀드 투자 는 수익을 거두는 목적보다는 명목상 투자가 필요할 경우에 참여하거나 심 지어 SI(전략적 투자)로 활용하는 경우도 많다. 그래서 애초에 목적 투자 비중을 이미 잃는 수익으로 생각하고 약정 비중 외에 나머지에서 손실된 수익을 채우려고 하는 인식까지 있는 편이다."

- 하지만, 모태펀드 투자의 관점에서는 단순히 콘텐츠산업 장르 구분을 기준으 로 성숙분야와 미성숙 분야를 나누는 것은 무의미

- 같은 콘텐츠 산업 장르 내에서도 세부장르에 따라 투자가 활발하게 일어나 고 있는 활성화된 분야가 있고 투자가 일어나기 척박한 취약분야가 존재 - 웹툰이나 게임과 같이 매출액이나 수출액에서 높은 성과와 성장률을 보이 고 있음에도 몇몇 소수 플랫폼이나 제작사가 시장을 점유하고 있을 경우 모 태펀드와 같은 투자는 활발하게 일어 날 수 없음

- 따라서 콘텐츠 각 장르뿐 아니라, 세부 장르까지 포함해서 너무도 다른 성 격과 특성을 지니는 영역에서 모두 포함되고 중요시하는 영역을 찾고 그에 따라 지표를 구성하는 접근이 필요

“문화계정 투자 시 가장 쉽게 할 수 있는 오해는 콘텐츠산업 각 장르의 산 업 성숙도를 투자에 있어서의 성숙도로 그대로 투영하는 것이다. 예를 들 어 게임 장르는 콘텐츠 산업 내에서는 성장기를 거친 성숙한 시장으로 보 고 있다. 하지만 투자에서 게임은 프로젝트 투자가 어려운 분야이며 $3 N$ 등과 같은 몇몇 대규모의 기업을 제외하고는 보장된 게임을 만들 수 있는 업체가 매우 드물다. 이에 따라 투자에 있어서 게임 장르는 미성숙 분야이 다. 또 같은 게임 장르 내에서도 세부장르에 따라 성숙도가 너무 다르기 때문에 모태펀드 문화계정 지표 설정 시 장르를 기준으로 일괄적으로 취약 과 미취약으로 나눠서 평가하는 것은 바람직한 방향이 아니다." 


\section{다. 성과지표 간 유기적으로 연결될 수 있도록 체계성 강화 필요}

- 현재 18 개의 모태펀드 각 계정에 일괄적으로 적용하고 있는 성과지표는 각 성과목표들이 파편적으로 이루어져 연결성이 떨어짐

- 2015년 성과지표의 경우, 과정-산출-결과에 해당하는 성과목표들이 유기 적으로 이루어져 있는데 현재의 지표는 투자금액확대, 민간LP확대, 피투자 기업 성과관리, 모태펀드 수익률 제고로 산출에 집중됨

“현재 문화계정 성과평가에 적용되고 있는 한국벤처투자의 지표는 모태펀 드에 각 계정에 통용될 수 있는 일반적인 성과목표 중심으로 이루어져 있 다. 특히, 성과목표 구성에 대해 읽어보고 다시 기억하면 기억이 잘 안날 정도로 구성력이 약한 느낌이 있다. 기존 유사평가에서 다루고 있는 논리 적 지표 구조를 참고하여 사업구성이나 가치사슬, 단계별, 주기별 분류 등 체계적인 성과목표 구축이 요구된다.”

- 성과목표에 대해 여러 개의 성과지표들이 구성되어 상호보완적으로 평가체계를 구성하고는 있지만, 대부분 모태펀드 일반에 대한 계량적인 평가로 이루어짐

- 계량적으로 측정이 불가능한 분야에 대해서는 비계량적인 지표를 보완적으 로 구성하여 타당성 확보가 필요함

\section{라. 문화계정은 정책기여도가 높은 분야}

- 문화계정의 가장 큰 특징 중에 또 하나는 제약이나 의무조항들이 형성하는 허 들이 너무 높다는 것이며, 이는 그만큼 문화콘텐츠 정책에 기여하는 바가 높다

는 것을 반증

- 문화계정 투자 시에는 투명성과 건전성을 고려하여 원금보장식 대출성 투 자금지, 임금 체불 제작사 투자 금지, 주요 출자자가 제작한 프로젝트 투자 금지 등 복잡한 그물망식 투자제한들이 존재

- 또한 표준계약서 의무 적용, 프로젝트 투자 시 문화산업전문회사 의무등록, 공연예술 분야 투자 시 공연전산망에 정보제공 동의 의무 등 지켜야할 준수 의무 사항도 다수 
- 다른 계정과 다르게 의무와 제한을 둠으로써 모태펀드의 자금이 들어가는 분 야에 제도 정착에 기여하고 정책적인 역할을 하게 만드는 기능을 하고 있음

“표준계약서 적용, 목적 투자와 별도로 문화산업 의무투자 비율 산정 등과 같은 진입장벽은 운용사 입장에서 문화계정을 꺼리게 하는 큰 요인 중에 하나이다. 심지어 중진계정 등에서도 문화콘텐츠 투자는 가능하며, 중진계 정 등과 같은 다른 계정에서 문화콘텐츠 투자를 할 경우 그러한 제약에서 자유로울 수 있기까지 하다. 군이 수익성를 바라고 콘텐츠 투자를 진행할 경우 문화계정의 투자는 큰 이점을 가지기 어렵다. 따라서 이러한 제약들 이 정책적인 기여를 하고 그러한 목적으로 의무조항들을 만들었다면, 문화 계정은 정책기여에 대한 평가가 이루어져야하는 것이 합리적이다.”

- 문화계정 운용 시, 대다수의 투자대상 프로젝트나 기업들은 영세하거나 초기 사업자들이 많기 때문에 운용사에서는 운용관리과정에서 일정부분 엑셀러레 이터 역할을 담당하는 부분도 있음

- 투자한 기업이나 프로젝트가 성공해야 수익을 거두기 때문에 운용사 입장 에서는 더 기업면모를 갖추고 경쟁력을 갖출 수 있게 관리와 운영지원, 컨 설팅의 역할을 하게 되는 경우가 많음

- 지표 선정 시에도 이러한 관리 및 컨설팅 관련 기여 부분도 성과에서 고려 해볼 영역

“모태펀드 문화계정 운영 초기에는 콘텐츠 산업에서 투자 개념의 이해도가 부족했기 때문에 주먹구구식으로 자본이 투입되고 체계성 없이 낭비되는 일들이 비일비재하였다. 운용사 입장에서는 운용의 편의성이나 수익성을 위해서라도 투자처를 관리하고 선진적인 시스템이 도입될 수 있도록 도와 야 했다. 이러한 과정에서 교육을 제공한다던지 일정 부분에 대해 컨설팅 을 해줄 수 있는 경우가 많아 졌다. 성과지표는 어떤 면에서 모태펀드의 방향성을 제시하는 디렉션이 될 수 있기 때문에 이러한 정책적인 기여를 더 강화해야한다면 지표에도 관련 내용들을 포함하는 것이 효과적일 것으 로 예산된다.” 


\section{제3절 소결}

- 지표의 체계성과 논리성을 갖추기 위해서는 각 항목들이 같은 기준과 계위 내 에서 묶여야 하며, 그 중분류들이 유기적인 논리 흐름으로 연결되어 구성되어 야 하는 것이 지표를 활용하고 이해하는 입장에서 효과적

- 사례분석을 했던 사다리펀드는 펀드운용 과정에 따라 계획-실행-성과-효과 로 성과 지표를 구성했고 콘텐츠 경쟁력 평가 지표는 콘텐츠 산업의 가치사 슬 구조에 따라 기획-제작-유통으로 평가지표를 구성

- 각 지표들의 묶음들이 파편적으로 이루어져 있는 현재 지표의 문제점을 극 복하기 위해서 논리 흐름이나 일정 기준에 따라 연계성 있게 지표를 구성하 는 노력이 필요

- 문화계정만이 지니는 특성을 세부적으로 분석하여 각 특성이 모태펀드 성과에 어떠한 영향을 미치는지 살펴봐야하며, 지표설정 시에 문화계정의 특성을 반 영하는 지표 개발이 절실

- 문화계정은 콘텐츠 산업의 다양한 장르를 포괄하고 있기 때문에 영역이 매 우 다양하고 장르의 속성 뿐 아니라 세부장르에서 이루어지는 투자환경과 투자 성격이 매우 다르게 나타남

- 또, 문화계정 운용 시 제약과 의무사항들이 까다롭게 배치되어 있어 투자 난이도가 높지만, 그로 인해 정책적으로는 많은 기여점이 있음

- 특히, 문화계정의 가장 큰 특징은 기업 지분 투자뿐 아니라 프로젝트 투자가 상당부분 이루어진다는 것인데 프로젝트 투자는 기업지분 투자와는 전혀 다른 양상과 투자패턴이 나타남

- 투자 주기와 기간, 회수 규모 등 성립되는 조건에서부터 운용되는 방식에 이르기까지 프로젝트와 기업투자는 상이함이 크게 나타나기 때문에 성과도 
이들을 구분하여 평가할 필요가 있음

- 기존의 평가방식에서는 프로젝트의 성과를 파악하기 어려운 내용들이 많으 며 프로젝트 투자만이 지니는 순기능이 존재하여 이러한 기여에 대해 재평 가 역시도 요구되는 시점

- 정리하면, 사례분석을 통하여 성과지표 설정 시 논리적 연계성을 지녀야 한다 는 벤치마킹 포인트가 도출되었으며, 전문가 자문회의를 통해 문화계정만의 특성이 반영되는 지표 개발이 필요하다는 시사점을 확인

- 이에 지표개발 시, 거시적 관점에서 중분류의 논리적인 흐름을 개발해야함 과 동시에 세부적 관점에서 문화계정 만의 투자적 색체와 장단점을 반영해 야 한다는 결론을 얻을 수 있었음 
모태펀드 문화계정 성과지표 개발 연구

제4장

\section{모태펀드 문화계정 성과지표 개발}





\section{제1절 성과지표 개발 방향성}

\section{1. 성과지표 개선 및 개발 방향}

- 앞서 진행한 모태펀드 문화계정 현황분석, 기존 평가지표 분석, 사례분석, 전 문가 자문회의인터뷰 등의 결과물들을 종합정리하여 모태펀드 문화계정의 지 표개발 방향과 방안들을 도출

[그림 4-1] 모태펀드 문화계정 성과지표 개발 방향 및 방안 도출 과정

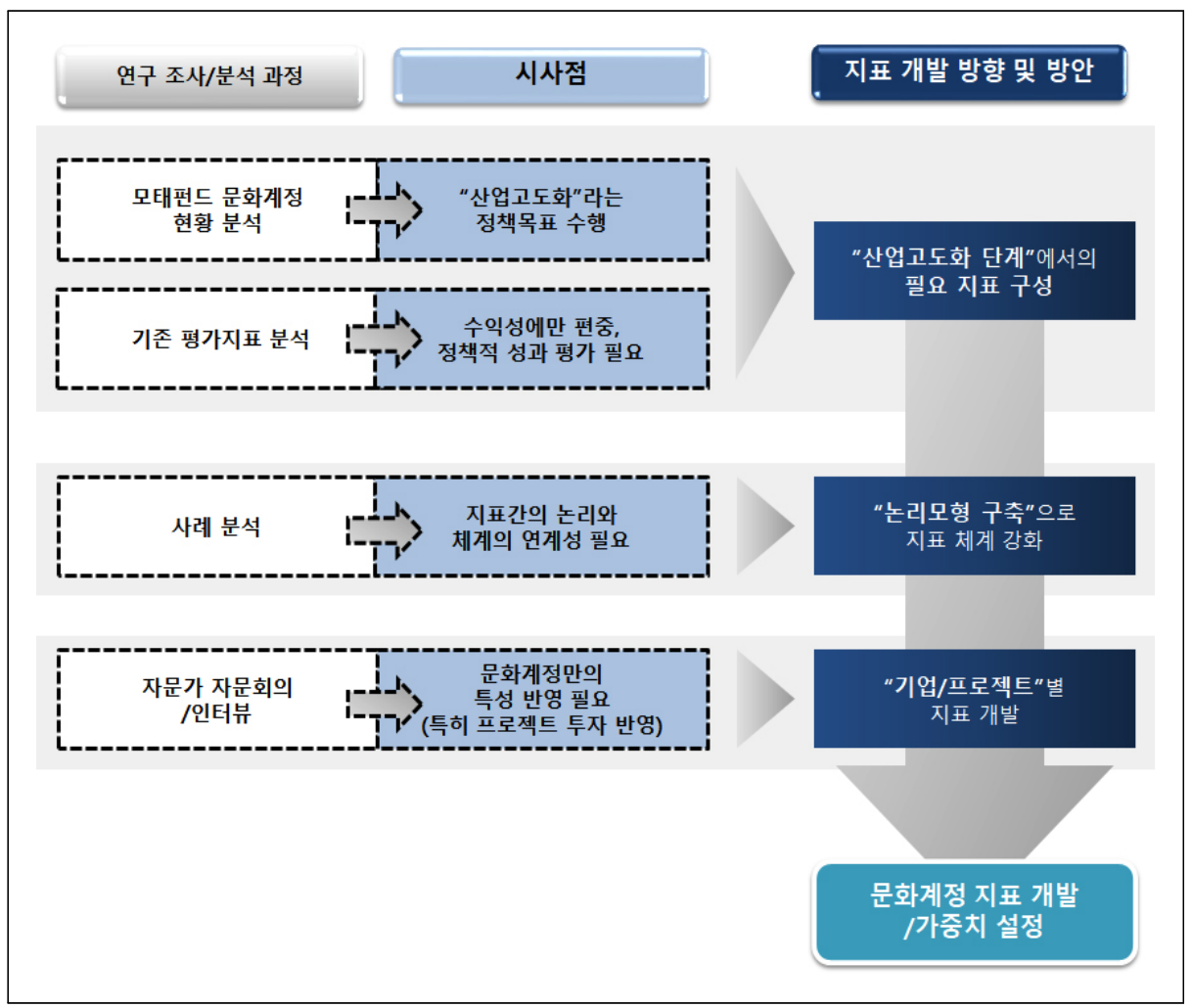


- 문화계정 현황분석에서는 모태펀드 문화계정의 의의와 성과, 한계들을 살펴보 면서 수익성보다는 산업고도화라는 정책목표를 수행하고 성과를 거두고 있었 음을 파악

- 특히, 문화계정의 정책적 역할을 강화하기 위해 다양한 제약과 의무사항들 을 설치하였고 정부의 정책방향 역시 취약분야, 제작초기 등 모험투자 분야 에 출자를 늘리면서 투자 사각지대 해소에 집중

- 문화계정의 기존 성과지표를 분석한 결과, 타계정과 같은 일괄적인 성과지표 로 구성되어 수익성 중심으로 평가되어 성과가 과소화되고 문화계정의 특성이 반영되고 있지 못하다는 문제점이 드러남

- 문화계정이 수익성보다 정책적 역할이 강조되고 성과 역시 산업고도화 기 여 측면에서 높게 나타난다는 점에서 문화계정의 방향 및 성과와 성과지표 간의 괴리가 나타나고 있었음

- 따라서 콘텐츠산업에서 모태펀드라는 정책지원이 필요한 지점이 무엇인지 제시하여 문화계정의 정책적 기여와 역할, 즉 콘텐츠 산업고도화에 대한 필 요지표를 구성해야 함

- 유사 정책펀드와 콘텐츠산업 성과지표를 중심으로 살펴본 사례분석에서는 대 다수의 지표들이 중분류 상에서 논리적 체계성을 갖추고 지표 간에 연계성을 지니고 있다는 벤치마킹 포인트를 도출

- 사례에서는 각 성과 지표들이 파편적으로 이루어지기 보다는 일정한 공통 체계 내에서 설명되어 정책목표성과 논리성이 제고됨 - 이에 논리모형 구축을 통하여 지표 구성의 체계 강화가 요구됨

- 문화계정 운용사, 모태펀드 운영기관, 학계 전문가 등을 대상으로 인터뷰와 자문회의를 진행한 결과 문화계정 만의 특성들이 반영된 지표가 개발되어야 함이 강조됨

- 특히 타계정과 다르게 프로젝트 투자가 주되게 진행되고 있는 바, 프로젝트 성 투자와 기업 지분투자와의 구분이 필요한 것으로 나타남 


\section{2. 영화산업으로 본 모태펀드의 산업 고도화 역할10)과 산업 활성화 모델}

- 한국 영화산업의 투자 변천과정은 크게 5 가지 단계로 구분할 수 있음

- 1990년대 초반 이전까지(1기)의 한국 영화 투자 주체는 국내외 외화 수입 배급업자 및 지방 극장업자들이 주도하였고 자금의 출처는 주로 영화산업 내부의 토착자본으로 형성

- 1990년대부터 1997년 외환 위기 이전까지(2기)는 삼성, 대우, SK 등 비디 오 플레이어나 비디오 테이프 등을 생산, 판매하던 대기업들의 영화산업 진 출이 이루어지며 제작비 증가와 제작 편수 증가 현상이 나타났으나, 비디오 붐이 케이블TV 붐으로 이어지지 않고 외환 위기를 맞이하며 대기업들이 대 거 철수함

- 1998년 2004년까지(3기)는 인터넷산업 중심의 벤처붐, 국민의 정부(김대 중정부)의 문화정책 추진과 더불어 기업 투자에 비해 투자금 회수가 빠른 프로젝트 투자에 새로운 창투사들이 재무적 투자자로 참여

- 2004 2011년까지(4기)는 영화산업으로 투입되는 자금이 늘어나면서 영화 제작이 대규모화되고 영화 제작 편수가 늘어나지만 반대로 편당 매출액이 떨어지는 역효과가 나타나기 시작하면서 투자 형태가 보수화되기 시작하고 대기업 메인투자 선호 현상이 나타남

[그림 4-2] 영화산업의 변천 과정

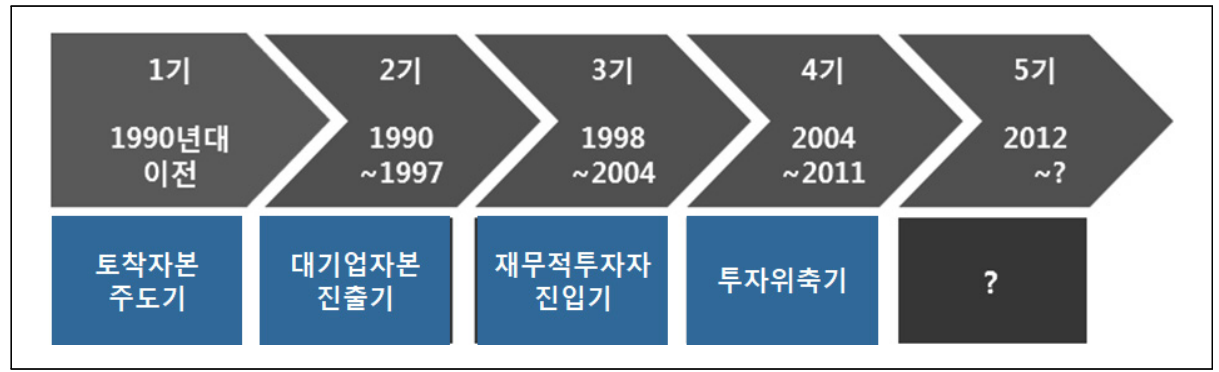

자료: 한국수출입은행(2014)

10) 김윤지(2014), 한국 영화산업 투자구조와 수익성 현황 및 개선방향, 한국수출입은행 의 내용을 요약함 
- 2012년 이후에는 영화 수익률 저조로 CJ E\&M, 쇼박스, 롯데엔터테인먼트, 뉴 등 4대 메이저 투자배급사 중심으로 영화 투자 시장 재편되고, 유니온투 자파트너스, 대성창업투자, $\mathrm{CJ}$ 창업투자 등 창투사들이 모태펀드와 함께 참 여하는 구조 형성

- 한국 영화산업에 대한 투자는 4기인 투자공급 과잉기를 거치면서 고도화 - 투자공급 과잉기에 수익률이 급감함에 따라 영화에 대한 투자가 보수화되 고 체계화되기 시작함

- 회계감사와 회계시스템 도입이 시작되고 주먹구구식 투자가 아니라 시나리오, 감독, 배우, 제작자 등을 총체적으로 검토하여 투자하는 방식이 생겨나게 됨 - 투자금을 한번에 투자하던 방식에서 기획 개발 단계, 시나리오 완성 단계, 캐스팅 단계 등으로 나누어 투입하여 리스트를 분배하는 방식이 생겨남

- 이와 같은 투자방식의 보수화와 체계화는 질 좋고 다양한 영화 투자자들을 유치하기 위한 제작사들의 노력으로 이어지게 됨

[그림 4-3] 연도별 영화산업 투자수익과 모태펀드 투입액

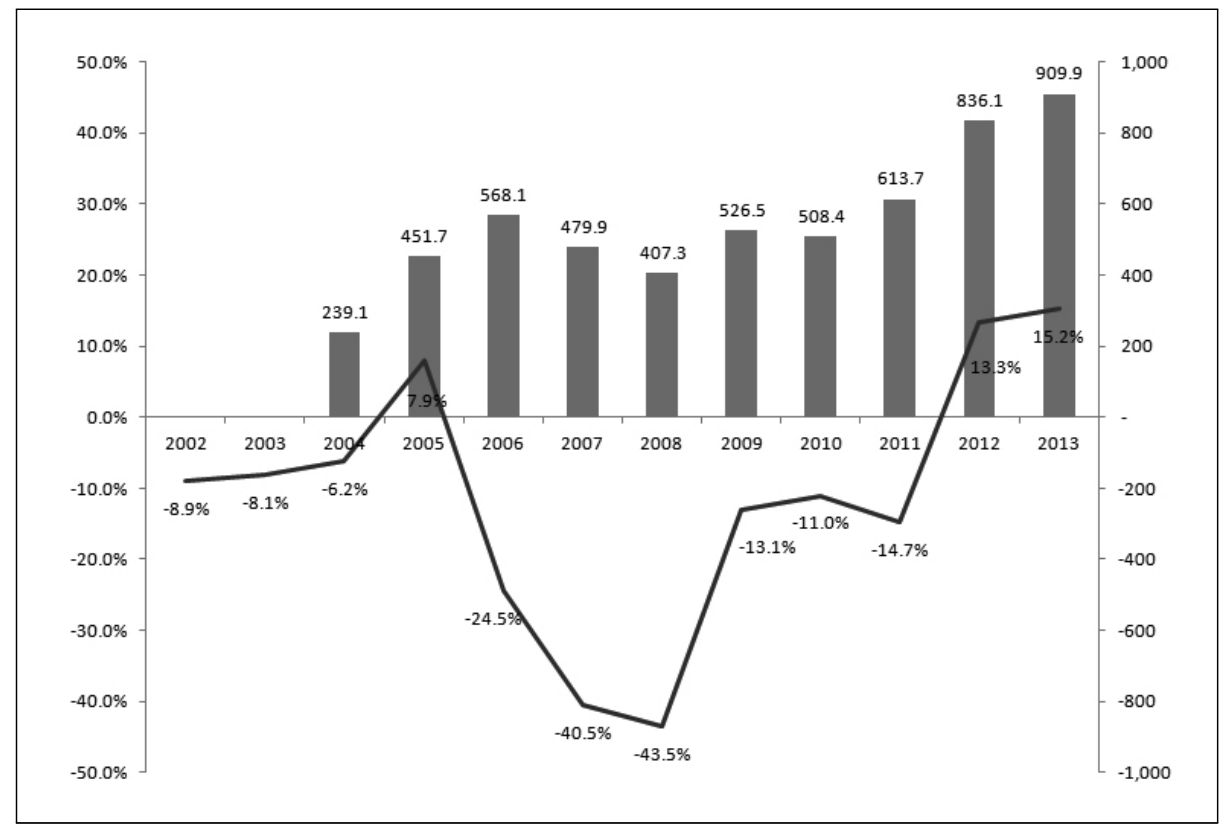

자료: 김윤지(2014), 한국 영화산업 투자구조와 수익성 현황 및 개선방향, 한국수출입은행 
- 모태펀드는 영화산업 투자 수익이 급감하던 시기에 투입되기 시작하여 영화산 업의 고도화 과정에 커다란 역할을 한 것으로 평가

- 모태펀드는 투자 공급 과잉기인 4기에 수익률의 감소와 그에 따른 투자의 위축기인 2007년부터 유력한 자금원 역할 수행

- 투자 위축기이기 때문에 정부의 공적 자금의 역할이 중요했고 정부 자금 특성상 다양한 통제 장치가 도입됨

- 프로젝트 별 별도 계좌를 사용, 프로젝트 후 회계 감사 의무화, 문화산업전 문회사(SPC) 제도 신설 및 의무화, 스텝인건비 미지급 제작사에 투자 금지, 표준계약서 의무화 등이 적용

- 투명한 수익 분배를 위해서는 관객수, 매출액, 좌석점유율 등에 대한 집계 가 필요했는데, 2003년부터 구축된 영화관입장권 통합전산망은 모태펀드 가 투입되던 시기와 비슷한 2008 2009년에 99\%의 극장 관객 수를 집계 하게 되었고 추후 $100 \%$ 까지 집계하여 투명성을 확보하게 됨

- 2007년부터 2013년까지 모태펀드 출자 투자조합에서 영화분야에 투자된 자금은 6,582 억 원인데, 이는 동 기간 국내 상업 영화 가운데 모태펀드 투 자가 이루어진 영화의 비중이 $77.6 \%$ 에 달함

- 결국, 영화산업의 발전과정에서 모태펀드는 산업 고도화에 상당부분 기여했으 며, 향후 민간투자가 활성화되어 지속적으로 성장하게 된다면 국가의 핵심 콘 텐츠산업으로 발전할 가능성이 있음

- 2000년 중후반의 수익률 감소와 투자위축의 위기 속에서 모태펀드 문화계 정과 영화계정이 영화에 집중투자 되면서 회복의 계기점 마련

- 모태펀드에는 자본 투입과 동시에 다양한 의무와 정책적 요구들을 따르도 록 하여 시스템 및 제도개선의 산업기반을 다지게 하고, 잠재력 있는 핵심 인력들의 제작 및 활동 기회들을 확장

- 산업에 자본이 풀리면서 메가히트 흥행작들이 발생하고 영화산업이 경쟁력 을 갖게 되면 자연스럽게 민간 투자가 활성화

- 국내 영화산업은 고도화의 과정까지는 어느 정도 이맀으나 아직 민간투자 가 더 요구되는 상황이며, 이러한 선순환이 지속된다면 글로벌 킬러 콘텐츠 들이 등장하게 될 것이고 국내영화산업은 글로벌 경쟁력 확보 
[그림 4-4] 영화산업에서의 모태펀드를 통한 산업고도화 모델

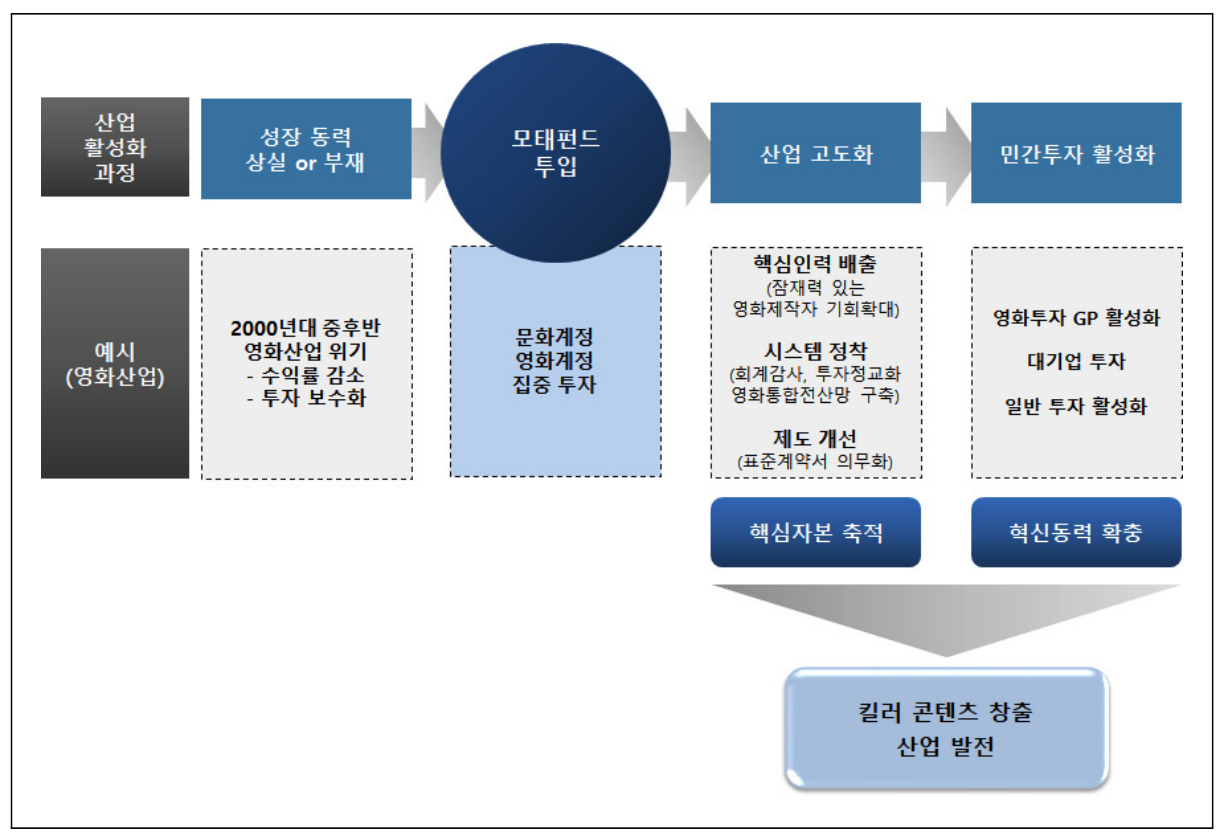

- 잠재성은 있으나 성장동력이 부족한 콘텐츠 영역에 대해 이러한 모태펀드 의 산업고도화 모델은 다양하게 적용이 가능한 모델

- 영화산업에서 축적된 경험을 바탕으로 위기에서 발전 임계점까지 버티게 해줄 수 있는 동력을 마련하고 산업성장의 기반을 구축하여 궁극적으로 산 업발전을 이룰 수 있는 성공모델을 더 확장할 필요가 있음

- 모태펀드 성과지표를 통해 간접적으로 정책 추구 방향을 제시할 수 있기 때문에 지표개발 시 산업고도화 측면을 깊이 있게 고려해야 함 


\section{제2절 문화계정 성과지표 개발}

\section{1. 성과지표 도출 과정}

- 산업단계에 따른 필요요소별 성과지표 파악을 통해 도출하였던 성과지표 후보 군 리스트를 논리모형 모델에 도입하고 연구진 및 전문가가 참석한 자문회의 를 통하여 최종 성과지표를 선정

- 문화계정이 속한 산업단계에서의 역할과 필요요소를 파악하여 이러한 핵심 요소가 반영된 성과지표 후보군들의 리스트를 정리

- 성과지표 후보군을 검토하고 나열하여 투입, 과정, 산출, 결과로 논리모형 에 맞춰 재구성(재구성 및 재배열 시 연구진과 전문가 자문회의를 통하여 지표를 추가하고 보완하는 정제화 과정을 거침)

[그림 4-5] 최종지표 도출 과정

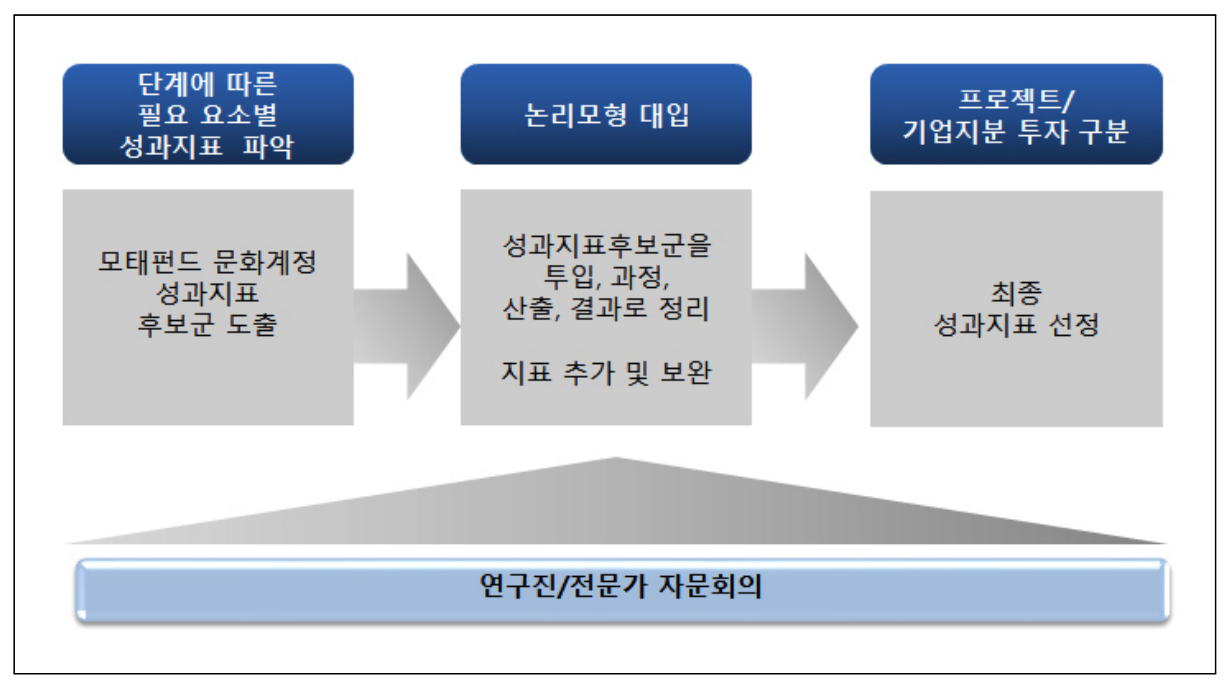


- 문화계정은 프로젝트성 투자(Project Financial)와 기업 투자가 각각 다른 성격으로 이루진다는 특징을 성과평가에서 명확하게 담아내기 위해 단기 (프로젝트)와 장기(기업)투자로 구분하여 지표를 별도로 구분

- 구분에 따라 최종지표를 설정하고 연구진과 전문가 자문풀에서 최종지표를 검토하고 최종 수정

\section{2. 산업발전 단계별 분석을 통한 성과지표 후보 도출}

- 모태펀드 문화계정은 콘텐츠산업을 위한 정책금융 중에서도 성장단계에 적합 한 자금조달 수단

- 정책금융은 특정 산업의 발전을 위해 정부가 특수 목적을 가지고 자금을 공급하는 지원정책을 의미하며, 일반적으로 예산을 배정하고 운용 공공기 관을 두어 수요자에게 필요 자금을 공급하는 형태로 이루어짐

[그림 4-6] 단계별 콘텐츠산업 자금조달 수단

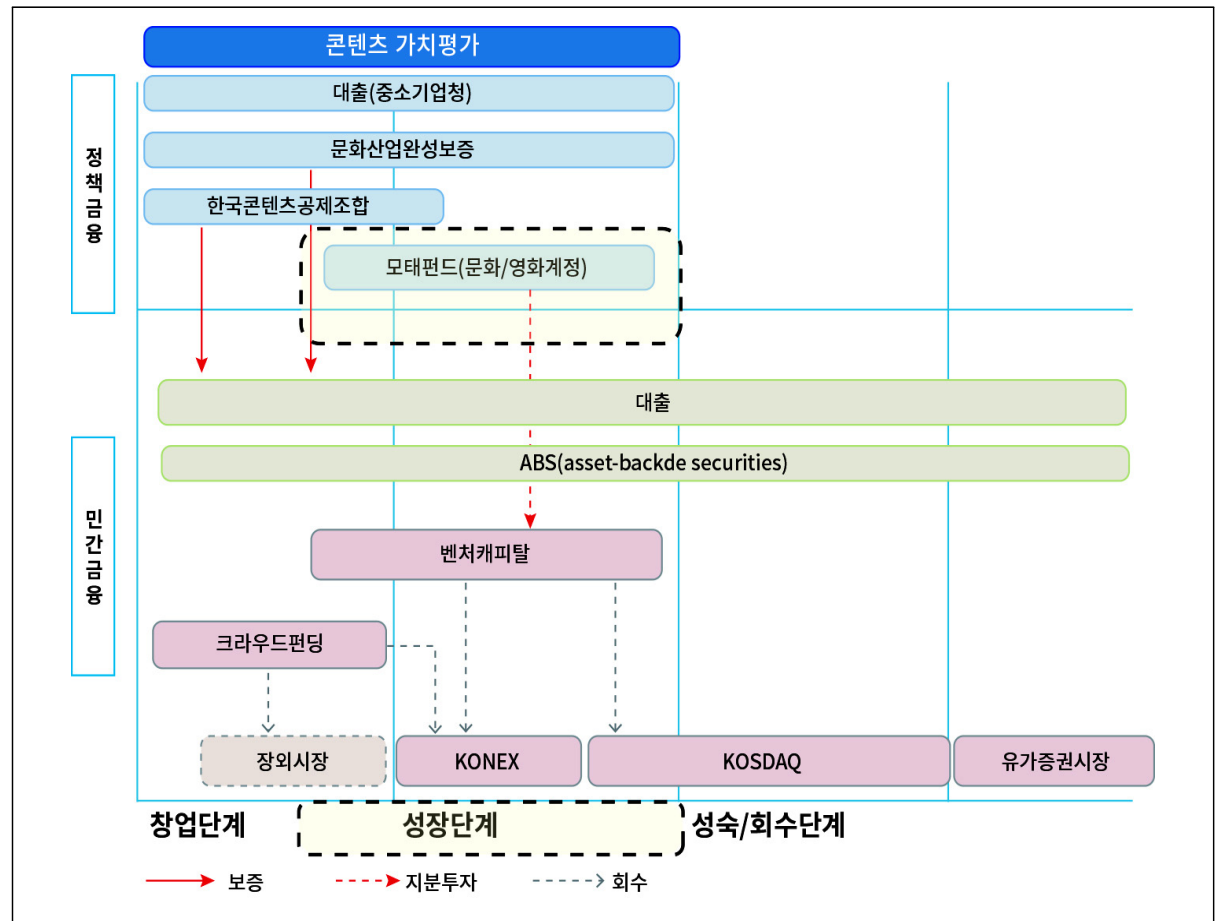

자료: 한국문화관광연구원(2016) 
- 콘텐츠산업에서 활용할 수 있는 대표적인 정책금융으로는 프로젝트금융형 대출(중소기업진흥공단), 완성보증(문화체육관광부, 기술보증기금), 한국콘 텐츠공제조합 보증 및 대출, 모태펀드 문화계정/영화계정 등이 있음

- 기존 연구에서는 콘텐츠산업에 적용되는 정책금융들을 단계별로 구분해볼 때 모태펀드는 성장단계에 적용되는 특성을 지닌 것으로 나타남

- 다만 여기서 단계별 구분은 피투자 대상의 성장주기를 기준으로 분류하여 산업적 차원이 고려되지 못하였으므로, 산업적 차원에서 모태펀드가 속한 단계를 파악할 필요가 있음

- 또, 앞서 살펴본 바와 같이 모태펀드 문화계정은 일반 펀드와 달리 수익성만이 아니라 '산업고도화'라는 정책적 목적을 달성하기 위한 정책금융

- 모태펀드 문화계정의 주된 목적은 산업의 성장가능성이 높지만 제작 기반 이 약하고 실패확률이 높아 투자유치가 어려운 분야의 투자를 활성화시켜, 근본적으로 산업을 성장시키고 고도화하는데 있음

- 실제로 콘텐츠 산업에서 모태펀드의 지원을 많이 받은 장르인 영화는 문화 계정과 영화계정의 투자를 통해 신진 제작자들을 양성하고 표준계약서 정 착과 같은 제도를 정비하는 등 산업고도화에 기여

- 이러한 관점을 Porter의 경쟁력 발전단계에 대입하면, 모태펀드는 산업발전 단계에서 '투자주도단계 또는 혁신주도단계 초반'에 적합한 정책지원

- Porter는 '경쟁력(Competitiveness)'에 입각하여 발전 단계의 특성을 파 악(1990)하는 이론을 제시

- (1) 요소주도단계(Factor Driven Stage), (2) 투자주도단계(Investment Driven Stage), (3) 혁신주도단계(Innovation Driven Stage), (4) 부(富)주 도단계(Wealth Driven Stage)로 구분

- 각 단계에서는 경쟁우위 관련 성격이나 특성에서 차이점이 나타나며, 이러 한 단계별 경쟁우위를 형성하는 기본 조건으로는 요소조건, 수요조건, 기업 전략 구조 및 경쟁조건, 지원 및 외부 조건 등의 환경 조건이라고 주장 
[그림 4-7] 산업발전 단계별 필요 요소와 모태펀드 투입시기

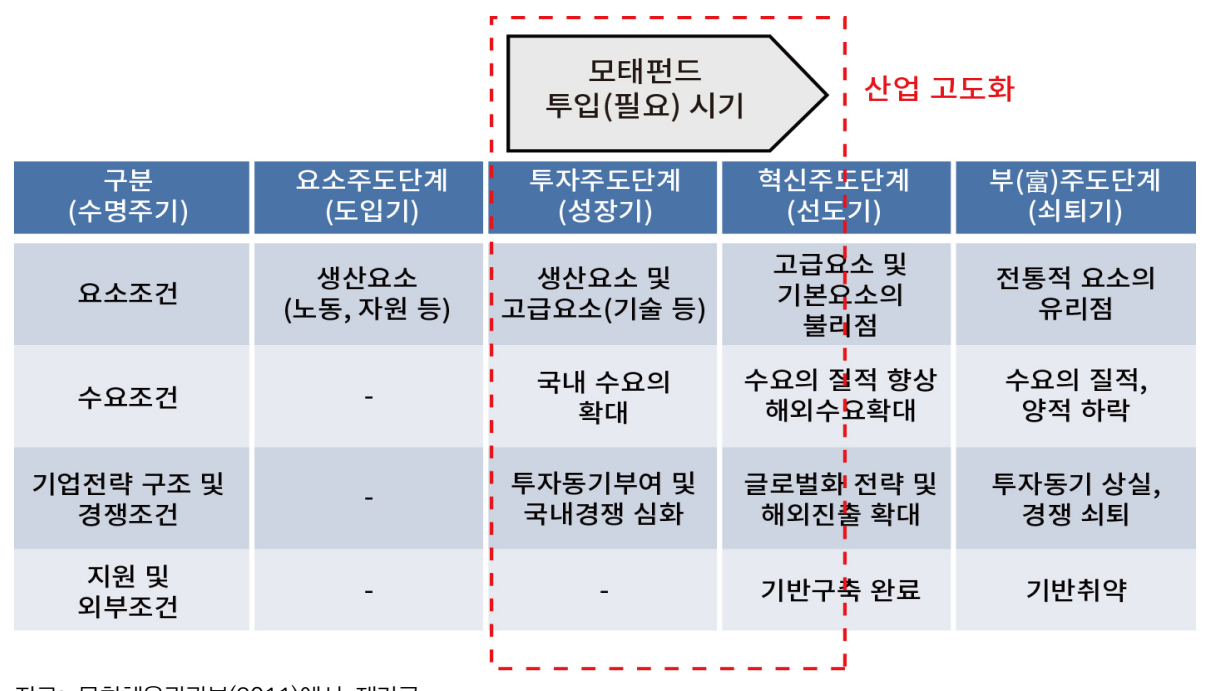

자료: 문화체육관광부(2011)에서 재가공

- 산업 고도화 단계라고 할 수 있는 투자주도단계와 초기 혁신주도단계에서 갖추 어야할 필수요소들을 콘텐츠산업에 적용하여 각 필요요소들에 맞는 지표를 개발 - 투자주도단계에서는 요소조건으로 생산요소 및 고급 요소들이 필수요건으 로 요구되며 수요조건으로는 국내 수요의 확대, 기업전략 구조 및 경쟁조건 에서는 투자동기 부여 및 국내경쟁 심화가 필요

- 혁신주도단계에서는 요소조건으로 고급요소 및 기본요소의 불리점, 수요조 건에서는 수요의 질적 향상과 해외 수요확대, 기업전략 구조 및 경쟁조건에 서는 글로벌화 전략 및 해외진출 확대가 필수조건

- 이 두 단계의 요소조건(부존/창출), 수요조건, 기업전략/경쟁 조건을 콘텐츠 산업에 적용하여 모태펀드 문화계정 성과지표들을 나열해보고 이들을 성과지 표 후보군으로 설정

- 기존 연구11)에서는 Poter의 경쟁력 모델의 각 요소들을 콘텐츠산업에 적용 하여 경쟁력 요소들을 재해석

- 재해석한 콘텐츠산업 관련 필요요소들의 내용을 구체화하고 주요성과를 파 악하는 지표에 연결하여 성과지표들을 개발하고 이들을 리스트업

11) 콘텐츠산업의 장르별 성장단계 분석과 지원전략, 문화체육관광부(2011) 
〈표 4-1〉 단계(투자주도단계 및 혁신주도단계 초)에 따른 필요요소별 성과평가 지표 도출 과정

\begin{tabular}{|c|c|c|c|c|}
\hline $\begin{array}{c}\text { 필요요 } \\
\text { 소 }\end{array}$ & 구성요소 & 콘텐츠산업 적용 내용 & & $\begin{array}{l}\text { 개발 성과지표 } \\
\text { 후보군 }\end{array}$ \\
\hline \multirow{4}{*}{$\begin{array}{l}\text { 요소 } \\
\text { 조건 } \\
\text { (부존/ } \\
\text { 창출) }\end{array}$} & 인적자본 & $\begin{array}{l}\text { - 창의적 전문인력 부존(고급인력과 기초인력) } \\
\text { - 콘텐츠산업 인력의 질적 수준 } \\
\text { (기능, 작업능력 등) }\end{array}$ & $\Rightarrow$ & $\begin{array}{l}\text { - 전문·고급 인력 창출 } \\
\text { - 고용증가 } \\
\text { - 인력 질적수준 }\end{array}$ \\
\hline & 자본 & $\begin{array}{l}\text { - 자본조달에 대한 상대적 접근성 } \\
\text { (투자자본창출) } \\
\text { - 업계의 접근이 용이한 자본조달방식의 존재 } \\
\text { 여부 } \\
\text { - 자본의 부존(제외) }\end{array}$ & $\Rightarrow$ & $\begin{array}{l}\text { - 자본 창출 } \\
\text { - 자금조달 용이성 } \\
\text { - 투자유치 성과 } \\
\text { - 후속투자 유치 } \\
\text { - 민간자금유치노력 }\end{array}$ \\
\hline & 요소의 창출 & $\begin{array}{l}\text { - 국가적인 차별화된 전문인력 양성시스템 } \\
\text { - 공동제작시설의 질적, 양적 수준 } \\
\text { - 혁신에 의한 요소창출 } \\
\text { (혁신적인 제작공정의 도입 등) } \\
\text { - 종업원의 사내교육, 훈련시스템 }\end{array}$ & $\Rightarrow$ & $\begin{array}{l}\text { - 컨설팅 및 관리 } \\
\text { - 인력 양성/훈련 } \\
\text { - 제작 질 제고 기여 } \\
\text { - 제작 양 확대 기여 } \\
\text { - 혁신성 }\end{array}$ \\
\hline & $\begin{array}{l}\text { 기술 } \\
\text { 저작권 }\end{array}$ & - 저작권, 특허권 등 산업재산권의 보유 수준 & $\Rightarrow$ & $\begin{array}{l}\text { - 저작권, 특허 창출 } \\
\text { - IP수익창출(OSMU) }\end{array}$ \\
\hline \multirow{3}{*}{$\begin{array}{l}\text { 수요 } \\
\text { 조건 }\end{array}$} & 국내수요 & $\begin{array}{l}\text { - 국내시장 공급자 수 대비 상대적인 시장규모 } \\
\text { - 시장 증가율 }\end{array}$ & $\Rightarrow$ & $\begin{array}{l}\text { - 투자수익성 } \\
\text { - 산업성장/육성 기여 } \\
\text { - 투자기업성장성 } \\
\text { - 투자기업안전성 }\end{array}$ \\
\hline & 수요의 구성 & $\begin{array}{l}\text { - 콘텐츠 수요의 세분화(소비자 선호의 다양성) } \\
\text { - 콘텐츠에 대한 소비자 욕구의 다양성 } \\
\text { - 소비자의 콘텐츠에 대한 평가, 개선의견 } \\
\text { 제시 등의 참여도, 적극성 }\end{array}$ & $\Rightarrow$ & $\begin{array}{l}\text { - 목적투자집행률 } \\
\text { - 고객/소비자 만족도 } \\
\text { - 다양성 확대 } \\
\text { - 언론노출 정도 } \\
\text { - 평점 }\end{array}$ \\
\hline & $\begin{array}{l}\text { 수요의 } \\
\text { 국제화 }\end{array}$ & - 국산콘텐츠에 대한 해외수요의 강도 & $\Rightarrow$ & $\begin{array}{l}\text { - 해외자본유치노력 } \\
\text { - 해외자본비율 } \\
\text { - 수출 } \\
\text { - 수상실적 } \\
\text { - 글로벌 영향력 확대 } \\
\text { - 국가브랜드제고 }\end{array}$ \\
\hline \multirow{3}{*}{$\begin{array}{l}\text { 기업 } \\
\text { 전략/ } \\
\text { 경쟁 } \\
\text { 조건 }\end{array}$} & 기업전략 & $\begin{array}{l}\text { - 경쟁강도 } \\
\text { - 경쟁전략 및 경영방식의 우수성 } \\
\text { - 업계 종사자들의 열의와 경쟁력 }\end{array}$ & $\Rightarrow$ & $\begin{array}{l}\text { - 생존율 } \\
\text { - 시장건전성 } \\
\text { - 신용등급변화 }\end{array}$ \\
\hline & $\begin{array}{l}\text { 시장구조 } \\
\text { (산업의 } \\
\text { 집중도) }\end{array}$ & $\begin{array}{l}\text { - 장르별 산업집중도 } \\
\text { (전체 업체 중 대형기업의 역할 및 비중) } \\
\text { - 선도적 기업의 존재 여부 }\end{array}$ & $\Rightarrow$ & $\begin{array}{l}\text { - 산업집중도 } \\
\text { - 대형기업 투자 정도 } \\
\text { - 배급사 기여 }\end{array}$ \\
\hline & 경쟁 & $\begin{array}{l}\text { - 잠재적 시장진입의 용이성 } \\
\text { - 대체재의 존재(제외) } \\
\text { - 시장개방도, 외국콘텐츠와의 경쟁 수준 }\end{array}$ & $\Rightarrow$ & $\begin{array}{l}\text { - 투자처풀 적절성 } \\
\text { - 개방성(투명성) } \\
\text { - 투자기업수 }\end{array}$ \\
\hline
\end{tabular}

자료: 문화체육관광부(2011)을 재가공 및 재해석 


\section{3. 논리모형 대입 및 최종지표 도출}

\section{가. 논리모형 개요}

- 논리모형은 사업의 구성요소, 주변여건 및 각 요소·상황에 대한 연관관계 등을 포함하여 사업의 특성을 살펴볼 수 있는 도구12)

- 논리모형은 사업이나 프로그램에 대한 투입(Input)이 이루어지는 시작부터 여러 가지 조직 내부적인 과정(Process)을 거쳐 산출(Output)이 나오고, 그것이 사업의 대상에 대한 어떤 결과(Outcome)로 이어지는지에 대한 논 리적인 관계를 보여주는 그림

- 평가에서 측정하고자 하는 요소들 간 연속성을 도표화하여 각 요소들을 가 로 지르는 정보의 흐름을 요약하여 제시

- 논리모형은 사업이 프로그램의 과정과 결과를 중시하던 전통적인 관리방식을 깨고 성과 위주로 평가하는 방식으로, 사업이나 프로그램의 전 과정에 대한 흐름도를 쉽게 파악할 수 있음

- 구성요소간의 관계를 도식으로 나타낸 하나의 프레임워크(framework)로, 주요 요소 간의 상관관계 및 인과관계를 파악하는데 유용함

- 논리모형은 사업의 목적이나 유형 등을 충실히 검토하여 사업의 관리, 평가 계획 설계, 사업의 개선방향 도출 등에 이용

- 사업의 구성요소, 내용, 방향 등의 시각화를 통해 직관적으로 사업을 이해할 수 있게 하여, 사업의 성과목표 및 성과지표를 쉽게 설정할 수 있도록 유도

- 논리모형은 크게 투입(Input), 과정(Process), 산출(Output), 결과(Outcome) 4가지 요소로 구성됨

- 투입은 사업이나 프로그램에 의해서 소비되고 제공되는 자원들을 의미

- 과정은 사업이나 사업의 목적을 성취하기 위해서 수행하는 구성요소

- 산출은 활동에 의해서 직접적으로 나타나는 산물로, 주로 제품이나 서비스 가 여기에 속하며, 성취된 양에 의해서 측정됨

12) 국가연구개발사업 표준성과지표, 과학기술정보통신부(2013) 
- 결과는 사업의 실시로 인하여 유발된 의도되거나, 의도되지 않은 경제·사회 적 조건의 변화를 총칭

[그림 4-8] 논리모형 구성

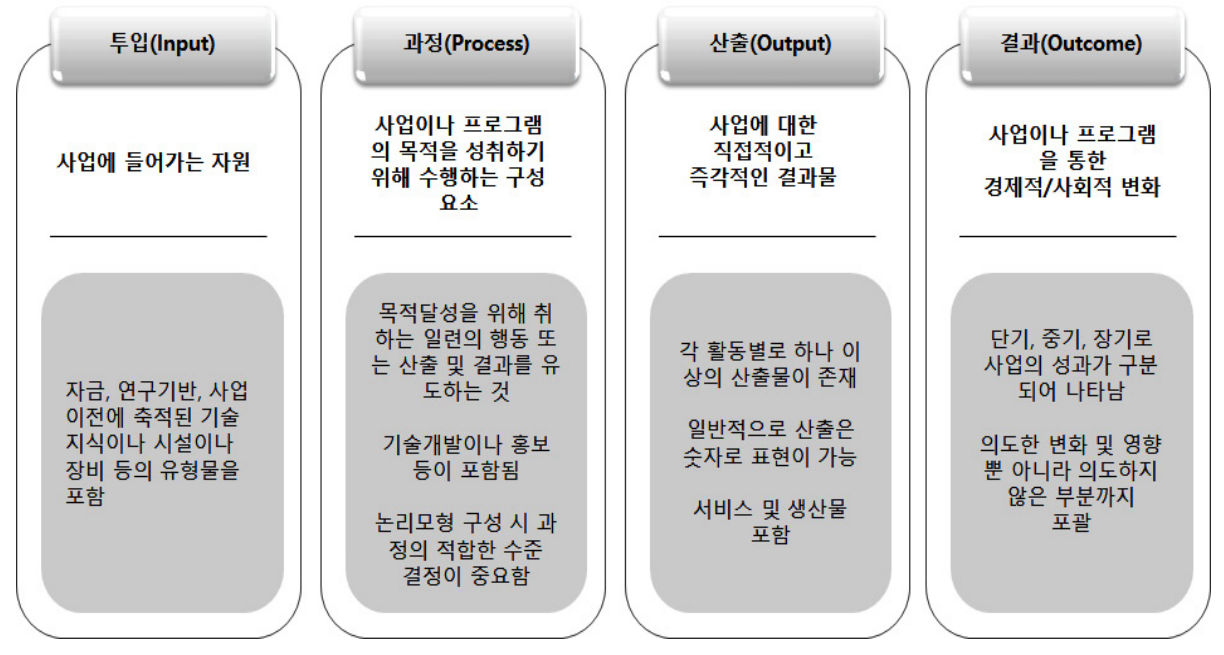

\section{나. 최종 성과지표 도출}

- 앞서 도출한 성과지표후보군의 리스트들을 논리모형에 대입하고 전문가 및 연 구진 회의를 통해 최종 성과지표를 선정

- 최종 지표 선정 시 연구결과를 바탕으로 실효성, 필요성, 목적 부합성의 기 준을 토대로 구성

- 논리모형 대입 과정에서 지표를 수정 및 보완하여 정제화된 최종지표 개발

- 그 결과, 최종 도출한 성과지표는 논리모형 4 개의 분류에 따라 프로젝트 투자 에서는 16 개, 기업 투자에서는 17 개로 각각 구성됨

- 프로젝트 투자와 기업 지분투자의 기본항목들은 공통으로 들어가되 각 투 자의 특성에 따라 필요한 지표들을 추가로 개발

- 투입에서는 공통지표가 목적투자 정도, 민간자금 유치 노력, 해외자본 유치노 력으로 구성되었고, 투자프로젝트 규모는 프로젝트 특수지표, 투자기업 규모, 피투자처 풀확장 노력은 기업 특수지표로 각각 구성 
- 목적투자 정도는 목적투자비율, 목적투자 집행률 등 출자 시 설정한 목적에 투자한 정도를 의미

- 민간자본 유치노력은 신규 LP개발, 민간비중 및 민간투자 확대, 평판 높은 LP 유치 등 민간자금 투자확대를 위한 노력 정도

- 해외자본 유치 노력은 해외LP 유치 등 해외 자본을 유치하기 위한 노력 정 도를 의미

- 투자 프로젝트 규모는 투자조합에서 투자를 진행한 프로젝트 건 수 등 그 규모를 의미

- 투자 기업 규모(수)는 투자조합에서 투자를 진행한 기업 건 수 등 그 규모를 의미

- 피투자처 풀확장 노력은 새로운 기업 발굴을 위한 피투자처 풀확장 노력 정도를 의미

〈표 4-2〉 투입 최종지표(안)

\begin{tabular}{|c|c|c|}
\hline 구분 & 지표명 & 정의 및 세부 내용 \\
\hline \multirow{3}{*}{ 공통지표 } & 목적투자 정도 & $\begin{array}{l}\text { - 목적투자비율, 목적투자 집행률 등 출자 시 설정한 목적에 투자한 } \\
\text { 정도 }\end{array}$ \\
\hline & 민간자본 유치노력 & $\begin{array}{l}\text { - 신규 LP개발, 민간비중 및 민간투자 확대, 평판 높은 LP 유치 등 } \\
\text { 민간자금 투자확대를 위한 노력 정도 }\end{array}$ \\
\hline & 해외자본 유치 노력 & - 해외LP 유치 등 해외 자본을 유치하기 위한 노력 정도 \\
\hline $\begin{array}{l}\text { 프로젝트 } \\
\text { 특수지표 }\end{array}$ & 투자 프로젝트 규모 & - 투자조합에서 투자를 진행한 프로젝트 건 수 등 그 규모 \\
\hline \multirow{2}{*}{$\begin{array}{l}\text { 기업 } \\
\text { 특수지표 }\end{array}$} & 투자 기업 규모 & - 투자조합에서 투자를 진행한 기업 건 수 등 그 규모 \\
\hline & 피투자처 풀확장 노력 & - 새로운 기업 발굴을 위한 피투자처 풀확장 노력 정도 \\
\hline
\end{tabular}

- 과정에서는 공통지표가 공모 투명성, 과정 공정성, 준법·건전성으로 구성되었 고, 프로젝트 지원 및 관리, 지원의 시의성은 프로젝트 특수지표, 피투자기업 지원 및 관리는 기업 특수지표로 각각 구성

- 공모 투명성은 얼마나 개방적이고 투명하게 공모를 진행했는지 투자과정에 서의 개방성 여부를 의미 
- 과정 공정성은 의사결정과정, 심사과정 등의 절차가 얼마나 공정했는지 여 부를 의미

- 준법·건전성은 규약 및 법령위반 건 수 등 투자관리 상에서의 건전성 정도 를 의미

- 프로젝트 지원 및 관리는 컨설팅, 비용관리 등 GP가 투자한 프로젝트에 대 해 얼마나 지원했는지 정도를 의미

- 지원의 시의성은 투자가 필요한 시점에서 이루어졌는지 여부

- 피투자기업 지원 및 관리는 컨설팅, 비용관리 등 GP가 투자한 기업에 대해 얼마나 지원했는지 정도를 의미

〈표 4-3〉 과정 최종지표(안)의 정의

\begin{tabular}{|c|c|c|}
\hline 구분 & 지표명 & 정의 및 세부 내용 \\
\hline \multirow{3}{*}{ 공통지표 } & 공모 투명성 & $\begin{array}{l}\text { - 얼마나 개방적이고 투명하게 공모를 진행했는지 투자과정에서의 } \\
\text { 개방성 여부 }\end{array}$ \\
\hline & 과정 공정성 & - 의사결정과정, 심사과정 등의 절차가 얼마나 공정했는지 여부 \\
\hline & 준법·건전성 & - 규약 및 법령위반 건 수 등 투자관리 상에서의 건전성 정도 \\
\hline \multirow{2}{*}{$\begin{array}{l}\text { 프로젝트 } \\
\text { 특수지표 }\end{array}$} & 프로젝트 지원 및 관리 & $\begin{array}{l}\text { - 컨설팅, 비용관리 등 GP가 투자한 프로젝트에 대해 얼마나 지원했 } \\
\text { 는지 정도 }\end{array}$ \\
\hline & 지원의 시의성 & - 투자가 필요한 시점에서 이루어졌는지 여부 \\
\hline $\begin{array}{l}\text { 기업 } \\
\text { 특수지표 }\end{array}$ & $\begin{array}{l}\text { 피투자기업 지원 및 } \\
\text { 관리 }\end{array}$ & $\begin{array}{l}\text { - 컨설팅, 비용관리 등 GP가 투자한 기업에 대해 얼마나 지원했는지 } \\
\text { 정도 }\end{array}$ \\
\hline
\end{tabular}

- 산출에서는 공통지표가 수익성, 피투자기업 만족도, 해외매출로 구성되었고, 특수지표는 프로젝트 지표에서 화제성만 포함

- 수익성은 IRR, 수익배수, PME 등 투자 수익성 정도를 의미

- 피투자처 만족도는 투자를 받은 프로젝트 및 문화전문회사, 기업에서의 만 족도로 설문조사를 통해 도출할 항목

- 해외매출은 해외 진출 매출액, 해외매출 비중 등 해외에서의 매출 정도

- 화제성은 언론 노출 정도, 수상실적 등 대외적 화제 정도를 의미 
〈표 4-4〉 산출 최종지표(안)의 정의

\begin{tabular}{|c|c|c|}
\hline 구분 & 지표명 & 정의 및 세부 내용 \\
\hline \multirow{3}{*}{ 공통지표 } & 수익성 & - IRR, 수익배수, PME 등 투자 수익성 정도 \\
\hline & 피투자처 만족도 & - 투자를 받은 프로젝트 및 문화전문회사, 기업에서의 만족도 \\
\hline & 해외매출 & - 해외 진출 매출액, 해외매출 비중 등 해외에서의 매출 정도 \\
\hline $\begin{array}{l}\text { 프로젝트 } \\
\text { 특수지표 }\end{array}$ & 화제성 & - 언론 노출 정도, 수상실적 등 대외적 화제 정도 \\
\hline
\end{tabular}

- 결과에서는 공통지표가 고용증가, 산업육성기여, IP(OSMU)수익 창출로 구성 되었고, 특수지표는 기업 지표에서만 투자기업성장성, 생존율이 포함

- 고용증가는 투자를 통해 나타난 고용의 증가 정도를 의미

- 산업육성기여는 해당 산업의 매출액, 수출액 증대 등 해당 분야의 산업발전 기여 정도를 의미

- IP(OSMU)수익 창출은 투자한 프로젝트 및 기업에서 창출한 IP수익 정도 (웹툰의 영화화 등)를 의미

- 산업분산도는 투자포트폴리오에서 산업분산 정도를 의미(다양한 분야, 장 르, 규모 등 다양하게 투자될 경우 높은 점수)

- 국가브랜드제고는 투자한 기업의 성과를 통한 한류 및 국가 브랜드 이미지 제고 정도

- 투자기업성장성은 투자한 기업의 매출액, 기업가치 등의 성장 정도

- 생존율은 투자한 기업들의 생존율 정도를 의미

〈표 4-5〉 결과 최종지표(안)의 정의

\begin{tabular}{|c|c|c|}
\hline 구분 & 지표명 & 정의 및 세부 내용 \\
\hline \multirow{5}{*}{ 공통지표 } & 고용증가 & - 투자를 통해 나타난 고용의 증가 정도 \\
\hline & 산업육성기여 & - 해당 산업의 매출액, 수출액 증대 등 해당 분야의 산업발전 기여 정도 \\
\hline & $\mathrm{IP}(\mathrm{OSMU})$ 수익 창출 & - 투자한 프로젝트 및 기업에서 창출한 IP 수익 정도(웹툰의 영화화 등) \\
\hline & 산업분산도 & - 투자포트폴리오에서 산업분산 정도 \\
\hline & 국가브랜드제고 & - 투자한 기업의 성과를 통한 한류 및 국가 브랜드 이미지 제고 정도 \\
\hline \multirow{2}{*}{$\begin{array}{c}\text { 기업 } \\
\text { 특수지표 }\end{array}$} & 투자기업성장성 & - 투자한 기업의 매출액, 기업가치 등의 성장 정도 \\
\hline & 생존율 & - 투자한 기업들의 생존율 정도 \\
\hline
\end{tabular}


- 이들을 종합한 최종 성과지표는 다음 표와 같음

〈표 4-6〉 모태펀드 문화계정 최종 성과지표(안)

\begin{tabular}{|c|c|c|c|c|}
\hline \multirow{2}{*}{ 구분 } & \multicolumn{2}{|c|}{ Enablers } & \multicolumn{2}{|c|}{ Results } \\
\hline & 투입(Input) & 과정(Process) & 산출(Output) & 결과(Outcome) \\
\hline 프로젝트 & $\begin{array}{l}\text { (1) 목적투자 정도 } \\
\text { (2) 민간자본 유치 노력 } \\
\text { (3) 투자 프로젝트 } \\
\text { 규모(수) } \\
\text { (4) 해외자본 유치노력 }\end{array}$ & $\begin{array}{l}\text { (1) 공모 투명성(개방성) } \\
\text { (2) 프로젝트 지원 및 } \\
\text { 관리 } \\
\text { (3) 과정 공정성 } \\
\text { (4) 준법건전성 } \\
\text { (5) 지원의 시의성 }\end{array}$ & $\begin{array}{l}\text { (1) 수익성 } \\
\text { (2) 피투자처만족도 } \\
\text { (3) 해외매출 } \\
\text { (4) 화제성 }\end{array}$ & $\begin{array}{l}\text { (1) 고용증가 }(\mathrm{m} / \mathrm{h}) \\
\text { (2) 산업육성기여 } \\
\text { (3) IP수익창출(OSMU) } \\
\text { (4) 산업분산도 } \\
\text { (5) 국가브랜드제고 }\end{array}$ \\
\hline 기업 & $\begin{array}{l}\text { (1) 목적투자 정도 } \\
\text { (2) 민간자본 유치 노력 } \\
\text { (3) 투자 기업 규모(수) } \\
\text { (4) 해외자본 유치노력 } \\
\text { (5) 피투자처 풀확장 } \\
\text { 노력 }\end{array}$ & $\begin{array}{l}\text { (1) 공모 투명성(개방성) } \\
\text { (2) 피투자기업 지원 } \\
\text { 및 관리 } \\
\text { (3) 과정 공정성 } \\
\text { (4) 준법.건전성 }\end{array}$ & $\begin{array}{l}\text { (1) 수익성 } \\
\text { (2) 피투자기업만족도 } \\
\text { (3) 해외매출 }\end{array}$ & $\begin{array}{l}\text { (1) 고용증가 }(\mathrm{m} / \mathrm{h}) \\
\text { (2) 산업육성기여 } \\
\text { (3) IP수익창출(OSMU) } \\
\text { (4) 투자기업성장성 } \\
\text { (5) 생존율 } \\
\text { (6) 산업분산도 } \\
\text { (7) 국가브랜드제고 }\end{array}$ \\
\hline
\end{tabular}

\section{다. 세부평가 기준}

- 개발한 성과지표들을 측정할 수 있는 세부측정 기준들을 마련하여 성과 측정 을 구체화

- 투입의 세부평가 기준

- 목적투자정도는 해당 자펀드가 애초에 달성하고자 하였던 목적투자 달성 비 율과 이를 실제로 집행한 목적투자 집행률을 측정하는 계량지표들로 구성 - 민간자본 유치노력은 신규LP 유치수와 금액을 기준으로 한 민간투자 비중과 같은 계량지표와 민간자금 투자확대 노력과 같은 비계량 지표를 통해서 파악

- 해외자본 유치노력의 경우도 해외의 LP 유치수라든지 해외투자비중과 같은 계량지표와 해외투자확대 노력과 같은 비계량 지표를 혼합하여 구성

- 투자 프로젝트 규모는 말 그대로 투자를 진행한 프로젝트 건수를 반영

- 투자기업 규모도 투자를 진행한 기업의 수를 계량적으로 파악

- 피투자처 풀 확장 노력은 피투자처의 스펙트럼을 넓히려는 노력을 얼마나 
기울였는지 살피기 위해 신규 투자기업 발굴 수를 계량적으로 파악하고 피 투자처 풀확장 노력을 비계량적으로 동시에 파악

- 과정의 세부평가 기준

- 공모투명성과 과정공정성의 경우 계량적으로 파악하기 어려운 요소이므로 투자과정에서의 개방.투명성 정도와 의사결정 및 심사 절차에서의 공정성 을 비계량적으로 파악하는 것으로 세부평가 기준을 설정

- 준법성 및 건전성은 규약 및 법령의 위반 건수를 반영해 건수가 적을수록 높은 점수를 받을 수 있도록 구성하고 투자관리 상 건전성 정도를 비계량으 로 파악하여 계량에서 파악되지 못한 건전성을 파악

- 프로젝트이나 피투자기업의 지원 및 관리는 직접적으로 운용사가 피 투자 기업이나 프로젝트를 대상으로 컨설팅이나 교육프로그램을 몇 차례 진행했 는지 계량적으로 파악하고 프로젝트나 기업 지원 및 관리 노력도를 비계량 적으로 동시에 파악

- 지원의 시의성은 피투자 기업이나 프로젝트를 대상으로 만족도 조사를 수 행하고 동시에 지원의 시의성 정도를 비계량으로 측정

- 산출의 세부평가 기준

- 산출의 경우 계량적으로 명확히 파악되는 분야이므로 모두 계량적으로 측정

- 수익성은 내부수익률(IRR, Internal Rate of Return), 수익배수로 규모를 통해서 산출성과를 파악

- 피투자처 만족도는 과정지표의 지원시의성에서 시의성 만족도를 측정할 때 함께 설문조사를 진행하여 투자 프로젝트 및 기업의 만족도 정도를 파악

- 해외매출은 말 그대로 해외 매출액 규모와 전체 매출액에서 해외 매출액이 차지하는 비중을 반영하여 성과를 파악

- 화제성 역시 계량적으로 파악하는데, 투자 프로젝트 및 기업의 언론 노출 건 수와 수상실적 건 수를 기준으로 성과를 측정

- 결과의 세부평가 기준

- 고용 증가는 투자대상에서 창출된 고용 증가수에 대한 지표이며 특히 프로 젝트 투자의 경우 비정규적 인력들이 대다수를 차지하기 때문에, 1 인당 일 
한 시간을 반영(hour/man)하여 성과를 파악

- 산업육성 기여는 계량적으로 투자대상의 해당 산업의 매출액 증대와 수출 액 증대를 통해서 속한 시장의 유망성과 규모를 적용해 성과를 파악

- IP 수익 창출은 투자 프로젝트나 기업에서 창출한 IP를 통해 거둔 IP 총 수익액을 측정하며 OSMU(one source multi use)된 모든 콘텐츠 포괄

- 산업분산도는 허핀달-허쉬만 지수(HHI)를 통해 산업집중도를 파악하고 산 업의 집중도가 낮을수록 해당 산업이 분산되어 있음을 의미하기 때문에 역 산하여 성과를 반영

- 국가 브랜드 제고는 투자한 프로젝트 및 기업이 얼마나 국가 브랜드를 높이 고 한류에 기여했는지 비계량적으로 측정

- 투자기업의 성장성은 투자기업의 계량적 매출액 증대와 투자기업의 가치 상승을 동시에 파악하여 측정

- 생존율은 투자기업들이 투자이후 폐업하지 않고 얼마나 살아남았는지 생존 율을 파악하여 측정

〈표 4-7〉 모태펀드 문화계정 최종 성과지표(안)

\begin{tabular}{|c|c|c|c|}
\hline 관점 & CSF(핵심요인) & $\mathrm{KPI}($ 세부 핵심성과지표) & 방법 \\
\hline \multirow{12}{*}{ 투입 } & \multirow{2}{*}{ 목적투자정도 } & 목적투자 비율 & 계량 \\
\hline & & 목적투자 집행률 & 계량 \\
\hline & \multirow{3}{*}{ 민간자본 유치노력 } & 신규 LP유치 수 & 계량 \\
\hline & & 민간투자 비중(금액) & 계량 \\
\hline & & 민간자금 투자확대 노력 & 비계량 \\
\hline & \multirow{3}{*}{ 해외자본 유치노력 } & 해외 LP유치 수 & 계량 \\
\hline & & 해외투자 비중(금액) & 계량 \\
\hline & & 해외 투자확대 노력 & 비계량 \\
\hline & 투자 프로젝트 규모 & 투자 진행한 프로젝트 건수 & 계량 \\
\hline & 투자기업 규모 & 투자 진행한 기업 수 & 계량 \\
\hline & \multirow{2}{*}{ 피투자처 풀확장 노력 } & 신규 투자기업 발굴 건수 & 계량 \\
\hline & & 피투자처 풀확장 노력 & 비계량 \\
\hline
\end{tabular}




\begin{tabular}{|c|c|c|c|}
\hline 관점 & CSF(핵심요인) & KPI(세부 핵심성과지표) & 방법 \\
\hline \multirow{10}{*}{ 과정 } & 공모 투명성 & 투자과정에서의 개방. 투명성 정도 & 비계량 \\
\hline & 과정 공정성 & 의사결정/심사 절차에서의 공정성 & 비계량 \\
\hline & \multirow{2}{*}{ 준법·건전성 } & 규약 및 법령 위반 건 수(역산) & 계량 \\
\hline & & 투자관리 상 건전성 정도 & 비계량 \\
\hline & \multirow{2}{*}{ 프로젝트 지원 및 관리 } & 컨설팅, 교육프로그램 건 수 & 계량 \\
\hline & & 프로젝트 지원·관리 노력 & 비계량 \\
\hline & \multirow{2}{*}{ 지원의 시의성 } & 지원의 시의성 정도 & 비계량 \\
\hline & & 피투자 대상 시의성 만족도(조사) & 계량 \\
\hline & \multirow{2}{*}{ 피투자 기업 지원 및 관리 } & 컨설팅, 교육프로그램 건 수 & 계량 \\
\hline & & 기업 지원·관리 노력 & 비계량 \\
\hline \multirow{7}{*}{ 산출 } & \multirow{2}{*}{ 수익성 } & IRR & 계량 \\
\hline & & 수익배수 & 계량 \\
\hline & 피투자처 만족도 & 투자 프로젝트/기업 만족도(조사) & 계량 \\
\hline & \multirow{2}{*}{ 해외매출 } & 해외 매출액 & 계량 \\
\hline & & 해외매출 비중 & 계량 \\
\hline & \multirow{2}{*}{ 화제성 } & 언론 노출 정도(건 수) & 계량 \\
\hline & & 수상 실적(건 수) & 계량 \\
\hline \multirow{9}{*}{ 결과 } & 고용증가 & 고용증가(hour/man) & 계량 \\
\hline & \multirow{2}{*}{ 산업육성기여 } & 해당산업의 매출액 증대 & 계량 \\
\hline & & 해당산업의 수출액 증대 & 계량 \\
\hline & IP 수익 창출 & 투자 프로젝트/기업 IP 수익액 & 계량 \\
\hline & 산업분산도 & 산업집중도 HHI 역산 & 계량 \\
\hline & 국가 브랜드 제고 & 국가 브랜드 제고, 한류 기여 & 비계량 \\
\hline & \multirow{2}{*}{ 투자기업 성장성 } & 투자기업의 매출액 증대 & 계량 \\
\hline & & 투자기업의 기업가치 상승 & 비계량 \\
\hline & 생존율 & 투자기업들의 생존 비율 & 계량 \\
\hline
\end{tabular}




\section{제3절 가중치 산정}

\section{1. 가중치 산정 방법}

- 개발한 모태펀드 문화계정 지표의 평가기준이 다수이며 복합적으로 이루져 있 으므로 계층적분석법(AHP: analytic hierarchy processes)을 활용하여 가 중치를 산정

- AHP는 대표적 분석 방법론으로, 다수의 평가기준을 계층화하여 나타내는 경우에 효과적으로 활용되고 있음

- 주요 기준과 그 기준 하부의 세부 기준들을 분해하여 쌍대적으로 비교 하 고, 결과로 도출된 중요도의 최종결과 값을 산정하는 분석 방법

- 인간의 사고와 유사한 과정으로 문제를 분석하고 분해하여 구조화할 수 있 다는 점과 모형을 이용하여 상대적 중요도 혹은 선호도를 체계적으로 비율 을 척도화하여 정량적인 형태로 얻을 수 있다는 점에서 유용

- 절차는 간결하지만 척도 선정이나 가중치의 산정 절차, 민감도 분석 등에서 사용되는 각종 기법이 실증분석과 엄밀한 수리적 검정과정을 거쳐 채택된 방법들을 활용한다는 점에서 이론적으로도 타당성을 지니는 장점을 지님

- 각 항목별 평가지표의 가중치 도출을 위해 계층적법(AHP)에 따라 설문을 구 성 및 진행하고 그 결과를 분석

- 각 항목들의 상위속성 및 하위속성 간 쌍대비교를 진행하여 각 항목들 간의 상대적 중요도를 산정

- 응답자별 성과지표에 대한 쌍대비교 수치를 이용해 상대적 중요도를 계산 하고 개인별 중요도 수치를 하나로 통합하여 전체 응답자가 생각하는 평가 지표별 상대적 중요도를 산정 
- 개인별 응답의 논리적 일관성을 판정하기 위한 일관성 지수(CI)를 산출함.

0.1 이하인 경우 합리적인 평가, 0.2 이하일 경우 허용범위, 그 이상은 일관 성이 없다고 봄13)

[그림 4-9] 평가지표 우선순위 도출을 위한 AHP분석 절차

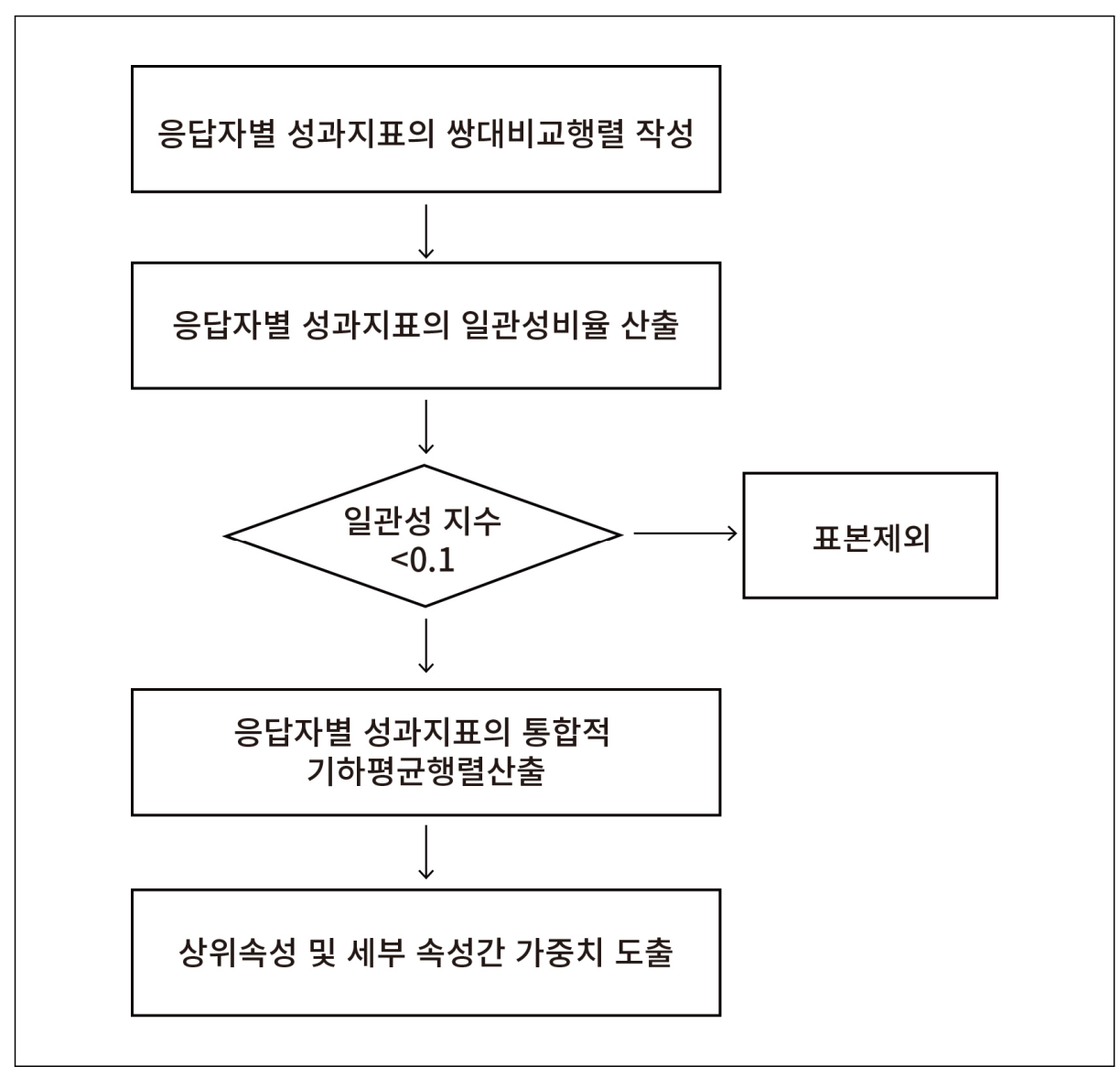

13) Saaty, T.L.(1994), How to make a decision: The analytic hierarchy process, Interfaces, 24(6), $19-43$ 


\section{2. $\mathrm{AHP}$ 설문 내용 및 가중치 산정 과정}

\section{가. AHP 설문 개요}

- $\mathrm{AHP}$ 를 통하여 복잡한 문제를 계층화하여 주 요인과 세부 요인들로 나누고 요인들에 대한 쌍대비교를 하기위해 문화계정 관련 전문가들을 대상으로 설문 조사를 진행

- 설문기간: 2020년 8월 1일 2020년 8월 20일

- 대상: 문화계정 출자조합 운용사(문화계정 운용 유경험 담당자), 학계 및 연 구계 전문가(문화계정 성과지표 개발 유경험자, 성과평가 유경험자, 문화계 정 관련 연구 유경험자), 콘텐츠산업 전문가 등 전문가 19명

- 방법: 설문조사에서 각 응답자의 쌍대비교 행렬을 작성하여 구한 일관성 지 수가 0.1 이상인 경우만을 이용

\section{나. AHP 설문 구성14)}

- 지표의 구성자체가 프로젝트 투자 지표와 기업지분 투자로 구분되어 있기 때 문에 두 지표를 나눠서 설문지를 구성했고, 각 설문마다 2계층으로 분류하여 설문지를 작성

- 제1계층 설문에서는 투입 지표, 과정 지표, 산출 지표, 결과 지표들 간의 상대적 중요도를 산출하기 위해 4 가지 지표의 중요도가 100점 만점이 되도 록 측정

- 제2계층 설문에서는 각 투입, 과정, 산출, 결과 지표의 구성 요소들 간의 상대적 중요도를 파악하기 위한 과정으로 각 지표들의 구성 항목들끼리 비 교하는 설문으로 구성

14) 구체적인 설문내용은 부록 자료를 참고 


\section{다. 가중치 산정15)}

- 계층분석법(AHP)의 최종 단계는 문제별 가중치 산정과 응답 신뢰성을 검증하 는 것

- 본 단계에서는 응답한 비교 값을 최종 산출하여 부문별 가중치를 산정한 뒤에 전체 응답자들이 신뢰성있고 일관성 있게 응답했는지 여부를 확인하 는 절차를 거침

- 가중치 계산방법은 각 문제 별 쌍대비교 값을 정방행렬로 배열한 뒤에 이를 문제별 가중치로 산정

- 각각의 지속가능부문 이슈를 $\mathrm{A} 1 \ldots . . . \mathrm{An}$ 로 두고 지속가능 정도를 $\mathrm{V} 1 \ldots . . \mathrm{Vn}$ 이 라 할 때 이슈별 쌍대비교 값을 정방행렬[A]로 배열하면 다음과 같음

[그림 4-10] 계층별 쌍대비교표

\begin{tabular}{|c|c|c|c|c|}
\hline & $\mathrm{A} 1$ & $\mathrm{~A} 2$ & $\ldots$ & $\mathrm{An}$ \\
\hline $\mathrm{A} 1$ & $\mathrm{~V} 1 / \mathrm{V} 1$ & $\mathrm{~V} 1 / \mathrm{V} 2$ & $\ldots$ & $\mathrm{V} 1 / \mathrm{Vn}$ \\
\hline $\mathrm{A} 2$ & $\mathrm{~V} 2 / \mathrm{V} 1$ & $\mathrm{~V} 2 / \mathrm{V} 2$ & $\ldots$ & $\mathrm{V} 2 / \mathrm{Vn}$ \\
\hline$\ldots$ & $\ldots$ & $\ldots$ & $\ldots$ & $\ldots$ \\
\hline $\mathrm{An}$ & $\mathrm{Vn} / \mathrm{V} 1$ & $\mathrm{~V} 2 / \mathrm{Vn}$ & $\ldots$ & $\mathrm{Vn} / \mathrm{Vn}$ \\
\hline
\end{tabular}

자료: 강진규·민병찬 역(2000), AHP이론과 실제

- 위의 표에서 $\mathrm{V} 1 / \mathrm{V} 1$ 은 $\mathrm{A} 1$ 자신에 비교한 것으로 그 값은 1 임

- V1/V2는 A2에 비교한 A1의 중요도를 나타낸 값이고 $\mathrm{V} 1 / \mathrm{Vn}$ 은 An에 비교 한 $\mathrm{A} 1$ 의 쌍대비교 값을 의미함

15) Saaty,T.L.(1994), How to make a decision: The analytic hierarchy process, Interfaces, 24(6), 19-43. 
- 쌍대비교를 통한 가중치 산정법은 행렬을 먼저 작성해야함

$$
A=\left|\begin{array}{cccc}
a_{11} & a_{12} & \ldots . . a_{1 n} \\
a_{21} & a_{22} & \ldots . . & a_{2 n} \\
\cdot & \cdot & \cdot \\
\cdot & \cdot & \cdot \\
a_{n 1} a_{n 2} & a_{22}
\end{array}\right|
$$

- 비교 행렬 $\mathrm{A}$ 의 원소 는 $\mathrm{n}$ 개의 항목들 각각의 가중치를 $(\mathrm{i}=1,2 \ldots \mathrm{n})$ 라 할 때, 항목i와 j의 가중치 비율을 의미하고 이는 다음과 같이 나타 날 수 있음

$$
\begin{gathered}
a_{i j}=\frac{w_{i}}{w_{j}}(\text { for } i, j=1,2, \ldots, n) \\
(\mathrm{a}=\text { 원소, } \mathrm{w}=\text { 가중치 })
\end{gathered}
$$

- 따라서, 비교행렬 A를 Wn의 비율로 표현하고 계층 내 각 항목들의 가중치 를 구하기 위해 다음과 같은 가중치 벡터를 고려함

$$
\begin{aligned}
& A=\left|\begin{array}{ccc}
w_{1} / w_{1} & w_{1} / w_{2} & \ldots . . w_{1} / w_{n} \\
w_{2 /} w_{1} & w_{2} / w_{2} & \ldots \ldots w_{2} / w_{n} \\
\cdot & \cdot & \cdot \\
w_{n} / w_{1} & w_{n} / w_{2} & w_{n} / w_{n}
\end{array}\right| \\
& W=\left(\begin{array}{l}
w_{1} \\
w_{2} \\
\cdots \\
w_{n}
\end{array}\right) \\
& (a=\text { 원소, } w=\text { 가중치 })
\end{aligned}
$$

- 또한 가중치 에 대해 다음과 같은 식이 성립됨

$$
\begin{gathered}
n . w_{i}=\sum_{j=1} a_{i j} w_{j}(\text { for } i=1,2, \ldots, n) \\
\quad(\mathrm{a}: \text { 원소, } \mathrm{w} \text { :가중치 })
\end{gathered}
$$


- 일치성 분석

- 응답자가 주관적으로 판단한 요소 간의 중요도가 이행성의 공리를 만족시키 면서 얼마나 일관성 있게 응답하였는가를 알기 위해서 일치성 분석이 필요함

- 일치성분석을 하기 위해서는 첫째, 최대고유치(principal Eigenvalue) $\lambda$ $\max$ 를 산정해야하고, 둘째, $\lambda \max$ 를 이용하여 일치성지수(Consistency Index: CI)를 산정

- 또 셋째로, $\mathrm{CI}$ 를 이용하여 일치성비율(Consistency Ratio: $\mathrm{CR}$ )을 구하는 데, 이 일치성비율(CR)을 가지고 일치성 여부를 판단함

- $\lambda \max$ 산정

$-n \times n$ 정방행렬[A]와 $n \times 1$ 가중치행렬[W]를 곱하면 새로운 $n \times 1$ 가중 벡터행렬[Y]가 산정되는데, 이 가중벡터 행렬의 구성요소 $\mathrm{Y} 1 \ldots . . . \mathrm{Yn}$ 과 가중 치 W1.....Wn을 이용하여 $\lambda \max$ 를 얻을 수 있음

$$
\begin{gathered}
{[A] X[W]=[Y] \text { 이고, }\left(Y_{1} / W_{1}+Y_{1} / W_{2}+\ldots+Y n / W n\right) / n=\lambda \max } \\
(\lambda \text { max: 최대고유치, } Y \text { :가중벡터행렬 })
\end{gathered}
$$

- $\mathrm{CI}($ consistency index) 산정

- 일치성지수는 다음과 같이 계산됨

$$
\begin{gathered}
\mathrm{Cl}=\lambda \max -\mathrm{n} / \mathrm{n}-1, \lambda \max \geq \mathrm{n} \text { (단, } \mathrm{n}=\text { 행렬의 차원 }) \\
(\lambda \max \text { 최대고유치 })
\end{gathered}
$$

- 응답자들이 쌍대비교에서 완전히 일치되게 응답할 것으로 기대하지는 않지 만, 통상 CI이 0.1 이하이면 양호하게 응답한 것으로 간주하며 0.2 까지 허 용범위로 인정함 


\section{3. 가중치 산정 결과}

\section{가. 대분류 가중치 산정 결과}

- CI 값은 프로젝트투자 부분 세분류 중 하나인 과정(Process)의 CI 값이 0.116 로 근소하게 0.1 이상으로 계산되었고 이를 제외한 모든 CI 값이 0.1 이하로 일치성이 있는 것으로 판단됨

- 대분류는 프로젝트투자 부분에서 1순위 투입, 2 순위 과정, 3 순위 결과, 4 순위 산출로 나타났고 기업투자 부분에서 1순위 투입, 2순위 과정, 3순위 산출, 4 순위 결과로 나타남

- 가중치를 백분율로 계산하여 프로젝트투자 부분에서는 투입 48.5점, 과정 20.8점, 결과16.2점, 산출14.5점으로 산정

〈표 4-8〉 프로젝트투자 대분류 가중치 및 중요도(배점)

\begin{tabular}{c|c|c|c|c}
\hline 구분 & 대분류 & 가중치 & 중요도 순위 & 배점 \\
\hline \multirow{4}{*}{ 대분류 } & 투입 & 0.485 & 1 & 48.5 \\
\cline { 2 - 5 } & 과정 & 0.208 & 2 & 20.8 \\
\cline { 2 - 5 } & 산출 & 0.145 & 4 & 14.5 \\
\cline { 2 - 5 } & 결과 & 0.162 & 3 & 16.2 \\
\hline
\end{tabular}

- 가중치를 백분율로 계산하여 기업투자 부분에서는 투입 43.2점, 과정 20.3 점, 산출20.3점, 결과16.2점으로 산정

〈표 4-9〉 기업투자 대분류 가중치 및 중요도(배점)

\begin{tabular}{c|c|c|c|c}
\hline 구분 & 대분류 & 가중치 & 중요도 순위 & 배점 \\
\hline \multirow{4}{*}{ 대분류 } & 투입 & 0.432 & 1 & 43.2 \\
\cline { 2 - 5 } & 과정 & 0.203 & 2 & 20.3 \\
\cline { 2 - 5 } & 산출 & 0.203 & 3 & 20.3 \\
\cline { 2 - 5 } & 결과 & 0.162 & 4 & 16.2 \\
\hline
\end{tabular}




\section{나. 세분류 가중치 산정 결과}

- 세분류는 대분류에서 산정된 각각의 과정에서의 가중치를 바탕으로 각각의 세 부지표 가중치를 곱하여 산정함

- 프로젝트투자와 기업투자 부분의 세부지표를 각각 산정함

〈표 4-10〉프로젝트투자 세분류 가중치 및 중요도(배점)

\begin{tabular}{|c|c|c|c|c|c|}
\hline 구분 & 대분류 & 세분류 & 가중치 & 중요도 순위 & 배점 \\
\hline \multirow{18}{*}{$\begin{array}{c}\text { 프로젝트 } \\
\text { 투자 } \\
\text { 세분류 } \\
\text { 산정 }\end{array}$} & \multirow{4}{*}{$\begin{array}{c}\text { 투입 } \\
\text { (48.5) }\end{array}$} & 목적투자 정도 & 0.555 & 1 & 26.9 \\
\hline & & 민간자금 유치 노력 & 0.224 & 2 & 10.9 \\
\hline & & 투자 프로젝트 규모 & 0.145 & 3 & 7.0 \\
\hline & & 해외자본 유치노력 & 0.075 & 4 & 3.6 \\
\hline & \multirow{5}{*}{$\begin{array}{l}\text { 과정 } \\
(20.8)\end{array}$} & 공모 투명성(개방성) & 0.249 & 2 & 5.2 \\
\hline & & 프로젝트 지원 및 관리 & 0.292 & 1 & 6.1 \\
\hline & & 과정 공정성 & 0.189 & 3 & 3.9 \\
\hline & & 준법·건전성 & 0.123 & 5 & 2.6 \\
\hline & & 지원의 시의성 & 0.148 & 4 & 3.1 \\
\hline & \multirow{4}{*}{$\begin{array}{c}\text { 산출 } \\
\text { (14.5) }\end{array}$} & 수익성 & 0.529 & 1 & 7.7 \\
\hline & & 피투자처 만족도 & 0.248 & 2 & 3.6 \\
\hline & & 해외매출 & 0.141 & 3 & 2.0 \\
\hline & & 화제성 & 0.082 & 4 & 1.2 \\
\hline & \multirow{5}{*}{$\begin{array}{c}\text { 결과 } \\
(16.2)\end{array}$} & 고용증가 & 0.289 & 2 & 4.7 \\
\hline & & 산업육성기여 & 0.340 & 1 & 5.5 \\
\hline & & IP수익창출(OSMU) & 0.189 & 3 & 3.1 \\
\hline & & 산업집중도 & 0.099 & 4 & 1.6 \\
\hline & & 국가브랜드제고 & 0.084 & 5 & 1.4 \\
\hline
\end{tabular}


〈표 4-11〉 기업투자 세분류 가중치 및 중요도(배점)

\begin{tabular}{|c|c|c|c|c|c|}
\hline 구분 & 대분류 & 세분류 & 가중치 & 중요도 순위 & 배점 \\
\hline \multirow{19}{*}{$\begin{array}{c}\text { 기업투자 } \\
\text { 세분류 } \\
\text { 산정 }\end{array}$} & \multirow{5}{*}{$\begin{array}{c}\text { 투입 } \\
(43.2)\end{array}$} & 목적투자 정도 & 0.455 & 1 & 19.6 \\
\hline & & 민간자금 유치 노력 & 0.202 & 2 & 8.7 \\
\hline & & 투자 기업 규모(수) & 0.159 & 3 & 6.9 \\
\hline & & 해외자본 유치 노력 & 0.079 & 5 & 3.4 \\
\hline & & 피투자처 풀확장 노력 & 0.104 & 4 & 4.5 \\
\hline & \multirow{4}{*}{$\begin{array}{l}\text { 과정 } \\
(20.3)\end{array}$} & 공모 투명성(개방성) & 0.306 & 2 & 6.2 \\
\hline & & 피투자기업 지원 및 관리 & 0.388 & 1 & 7.9 \\
\hline & & 과정 공정성 & 0.208 & 3 & 4.2 \\
\hline & & 준법·건전성 & 0.098 & 4 & 2.0 \\
\hline & \multirow{3}{*}{$\begin{array}{l}\text { 산출 } \\
\text { (20.3) }\end{array}$} & 수익성 & 0.640 & 1 & 13.0 \\
\hline & & 피투자기업만족도 & 0.250 & 2 & 5.1 \\
\hline & & 해외매출 & 0.110 & 3 & 2.2 \\
\hline & \multirow{7}{*}{$\begin{array}{c}\text { 결과 } \\
(16.2)\end{array}$} & 고용증가 & 0.217 & 2 & 3.5 \\
\hline & & 산업육성기여 & 0.218 & 1 & 3.5 \\
\hline & & IP수익창출(OSMU) & 0.149 & 4 & 2.4 \\
\hline & & 투자기업성장성 & 0.171 & 3 & 2.8 \\
\hline & & 생존율 & 0.135 & 5 & 2.2 \\
\hline & & 산업분산도 & 0.062 & 6 & 1.0 \\
\hline & & 국가브랜드제고 & 0.048 & 7 & 0.8 \\
\hline
\end{tabular}



모태펀드 문화계정 성과지표 개발 연구

제5장

시사점 및 결론 



\section{제1절 연구의 시사점}

\section{ㅁ 문화산업 특성을 반영한 성과지표 구성}

- 기존의 수익성 위주의 성과 지표에서 탈피하여, 투자의 전 과정을 지표에 포괄시킴 - 타 영역 대비 관리 소요가 높은 문화계정의 특성을 반영하고자 수익성 이외에 이를 포괄하는 투입(input), 과정(process), 산출(output), 결과(outcome) 영역에 해당하는 다양한 항목들로 지표를 다변화

- 투입, 과정 부문에서는 타 분야에 비해 투자 활성화가 어려운 문화계정의 특성을 반영하여 목적투자 정도, 민간자금 유치 노력, 피투자처 풀확장 노 력 등의 항목을 포함

- 산출 및 결과 부문에서는 기존의 ‘수익성’을 포함하면서도 중장기적인 기여 부분을 측정하고자 고용증가, 산업육성 기여, 투자기업 성장성, 생존율 등 항목을 포함

- 그 외 산업분산도 등 취약분야를 포함한 다양한 분야에 투자할수록 더 좋은 점수를 얻을 수 있도록 구성

- 한류효과 등 직접적인 효과 측정이 어려운 문화산업의 간접 기여 정도를 성과 로 측정하기 위한 항목 편성

- 문화산업의 성과로 볼 수 있는 화제성, 해외매출, 국가 브랜드 제고 등도 항목에 포함시켜 특성을 반영함

- 문화산업 투자의 특성을 반영하기 위한 항목들로 구성

- 문화산업의 OSMU적인 특성을 반영하고자 IP수익창출 항목을 결과 부분에 포함시킴

- 초기 단계 자금 투입이 어려운 분야 특성을 고려하여 지원의 시의성, 피투 자처 만족도 등을 항목에 포함시킴 


\section{미앙르, 출자 분야에 구애받지 않는 성과지표 도출}

- 문화계정 투자의 실태를 반영하여 성과지표를 프로젝트와 기업 성과 지표로 차별화하여 구성

- 문화산업에는 다양한 장르 산업이 존재하기 때문에 문화산업의 특성을 반 영하기 위해서는 개별 장르에 해당하는 별도 지표를 구성하거나 몇 개 장르 를 묶어서 집단별 지표를 구성할 수 있음

- 그러나 장르별 지표를 구성할 경우 복잡도가 증가하여 명확한 성과 비교나 일반화가 어렵게 되고, 몇 개 장르를 묶는 것도 명확한 구분법이 없어 이루 어지기 어려움

- 문화계정에서의 투자가 프로젝트 투자와 기업 투자로 양분되는 현실을 반 영한 단순한 구분의 지표를 구성하고 장르에 구애받지 않고 평가가 가능한 지표로 구성함

- 매년 달라지는 출자분야에 상관없이 측정 가능한 일반화된 지표 구성

- 기존의 모태펀든 문화계정의 출자분야는 그 해의 정책 우선순위에 따라 편 성되는 경우가 많았음(가령, 출판 분야 투자가 강조되는 해에는 관련출자 분야가 신설)

- 매년 달라지는 출자분야에 구애받지 않으면서 출자분야별 성과를 측정할 수 있도록 보다 일반화된 지표를 구성함

\section{모태펀드 문화계정의 역할을 ‘산업고도화’ 측면으로 포지셔닝}

- 정책금융은 모태펀드 이외에도 대출, 완성보증, 가치평가 등 다양한 수단이 존재하고 기존의 지원사업도 있으므로 모태펀드 문화계정의 역할을 '산업 고 도화로 한정함

- 모태펀드는 국고를 기반으로 하기에 공공적인 측면에서 투자, 관리되어야 하면서도 수익성을 동시에 추구하는 모순성을 지님

- 공공성과 수익추구가 양립하기 위해서는 모태펀드 문화계정의 투자 분야가 단순히 취약분야를 지원하는 역할로 한정되어서는 안 됨 
- 때문에 취약 분야이더라도 동시에 성장가능성, 산업고도화 가능성이 높은 분야에 대한 투자로 역할이 한정되어야 할 것으로 보고 이러한 측면에 걸맞 는 지표를 구성함

- 공적 자금이 민간 시장에 투입되면서 시장을 더욱 투명화하고 체계화할 수 있 도록 지표를 통한 방향성 제시

- 모태펀드가 영화산업 분야에 있어 시장을 투명화하고 체계화하는데 기여하 였듯이, 공적자금이 문화산업의 다양한 분야에 투자되어 관리되는 과정에 서 시장의 공정성, 투명성 등을 높이는 역할을 할 수 있음

- 이에 과정(process) 영역에 투명성, 공정성, 시장건전성 등의 항목을 포함 시켜 공적 자금의 시장 관행 개선 및 투자 매력도를 높이기 위한 체계화 방 향성을 제시 


\section{제2절 연구의 한계 및 향후 연구방향}

\section{ㅁ 실무 적용을 위한 방안 마련}

- 연구에서 도출된 지표를 실제로 적용하기 위한 시뮬레이션 과정 필요

- 연구에서 제시한 지표의 실무 적용 가능성을 높이기 위해 그 동안 모태펀드 문화계정의 실제 투자 자료를 확보하여 시뮬레이션을 시도하고자 하였으나 투자 정보 협조 상의 한계와 인적, 시간적, 물적 비용의 제한 등의 한계

- 시뮬레이션 과정에서 일부 지표의 수정 및 변경이 가능할 것으로 보임

- 지표 활용을 위한 세부 지표의 구체화 방안 마련

- 향후 제시한 지표의 실제 적용을 위해서는 구분된 카테고리별 항목에 따른 세부지표를 구체화하고 이를 표준화하기 위한 추가 연구가 필요할 것임

\section{므 타 정책금융 수단과의 조화 방안 마련}

- 금융 투자 효율화를 위한 정책금융별 역할 조정 필요

- 금융 분야의 정책수단은 다양한 형태가 있고, 기업 입장에서는 민간분야 금 융도 활용할 수 있기 때문에 정책금융은 수단별로 그 역할이 조정될 필요가 있음

- 모태펀드 문화계정은 지금까지 '문화산업진흥기금' 의 대체로 인식되면서 지 금까지 그 역할이 기금과 혼돈되는 측면도 있었으나 본 연구에서는 '산업의 고도화라는 측면으로 모태펀드의 역할을 설정

- 향후 투자가 활성화되기 위해서는 모태펀드 문화계정 이외의 다른 정책금응 과의 역할 구분 및 조화 방향성 등이 보다 총체적으로 고민될 필요가 있음 


\section{참고문헌}

- 권호영·김규찬(2012), 「모태펀드 문화계정 재원 확충 방안 연구」, 한국콘텐츠진흥원.

- 김국진 외(2011), 「콘텐츠산업의 장르별 성장단계 분석과 지원전략」, 문화체육관광부.

- 김미현(2019), 「한국영화 제작자본에 대한 영상전문투자조합 정책의 기여도 평가」, 한국콘텐츠학회논문지, 19(9), 212-220.

- 김상욱(2014), 「콘텐츠산업 활성화를 위한 모태펀드 문화계정 운영개선 방안 연구」, 문화경제연구, 17(3), 105-138.

- 김윤지(2012), 「콘텐츠 산업 금융 활성화 방안」, 한국수출입은행.

- 구정한·김영도·이시연, 「국내 중소기업 정책금융 제도와 효과 분석」, 한국금융연구원.

- 박용린·김종민(2015), 「해외 정부 벤처캐피탈의 현황 및 시사점」, 자본시장연구원.

- 박재성·나수미(2019), 「국내외 VC·PE 제도 비교 및 벤처투자 활성화 방안」, 중소기 업연구원.

- 박찬욱·천정균·박윤제(2017), 「모태펀드 문화계정 운용 개선방안 연구」, 한국문화관 광연구원.

- 송원근·김준일(2014), 「중소기업 모태펀드 운용실태 분석」, 국회예산정책처.

- 신종원(2020), 「혁신금융의 주요 현안과 정책과제」, 산업연구원.

- 오규철(2012), 「모태펀드 형태의 서울형 신성장동력 희망펀드 조성방안 연구」, 서울시.

- 이용관·박찬욱·이성민·한정임·이수현(2018), 「지역 콘텐츠산업 경쟁력 지표 개발 기초연구」, 한국문화관광연구원.

- 이동호·이호용·박준민·전병훈(2019), 「2018년 농식품투자모태조합 운영성과평가 보고서」, 농업정책보험금융원.

- 이태호·이정우(2017), 「콘텐츠 기업육성을 위한 콘텐츠 금융지원 정책조사」, 한국콘 텐츠진흥원.

- 황준호·임희수·정인숙·김성철(2011), 「콘텐츠 경쟁력 평가방안 연구」, 방송통신위원회.

- Cochrane, J. H.(2005), The Risk and Return of Venture Capital, Journal of Financial Economics 75 , p. 3-52 
- ICAEW. Creative Industries Federation(2015), Creative Industries-routes to finance (A guide to sources of funding and investment for arts, cultural and creative organisations).

- Lerner, J. (2009) Boulevard of Broken Dreams: Why Public Eforts to Boost Entrepreneurship and Venture Capital Have Failed-and What to Do About it, Princeton University Press.

- The British Business Bank(2017), The British Business Bank Anual Report and Account 2017. 


\section{ABSTRACT}

\section{A Study on the Development of Performance Indicators for Cultural Account of Fund of Funds}

The main goal of the research is to develop performance indicators that are consistent with the policy objectives of Cultural Account of Fund of Funds and the current content industry.

Fund of Funds is indirect financing with both sides to achieve not only profitability but also policy objectives. Nevertheless, it has been subjected to overall performance evaluation centered on profitability, regardless of other accounts. This study focused on these problems.

Through the analysis of the current situation and interviews with workinglevel personnel, it was found that there are many difficult restrictions and obligations in the cultural account to achieve the policy objectives. In addition, the government's policy direction also strengthened support for investment blind spots, and provided support for areas that require investment despite high investment risk. This means that Cultural Account of Fund of Funds is financial policy system with clear policy purpose. Particularly, it was analyzed that Cultural Account of Fund of Funds started in the mid-2000s and played the role of "industry advancement" in the contents industry. Cultural Account of Fund of Funds was found to have contributed greatly to the establishment and improvement of the system and the production of core manpower through investment in the film industry. By synthesizing these implications, in this study, the role of "industrial advancement" was set as the main role of Cultural Account of Fund of Funds, and the final indicator was developed by introducing 
a logical model. In addition, by dividing the corporate indicator and the project indicator, an indicator reflecting each characteristic was created, and the weight of each indicator was calculated through analytic hierarchy processes (AHP).

This study has a policy meaning in developing performance indicators reflecting the characteristics of the cultural industry and deriving performance indicators that are not restricted to genre and investment fields. In addition, the role of policy finance was clarified by positioning the role of Cultural Account of Fund of Funds in the aspect of industrial advancement.

\section{Keywords}

Fund of Funds, Cultural Account, Performance Indictors, Contents Investment 
모태펀드 문화계정 성과지표 개발 연구

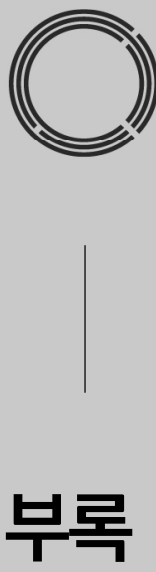





\section{문화계정 성과지표 전문가 AHP}

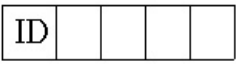

\section{안녕하십니까?}

본 조사는 문화체육관광부에서 모태펀드 문화계정의 특성을 반영한 성과지표를 개발하고 가중 치를 도촐하고자하는 목적으로 시행하고 있습니다. 모태펀드 문화계정의 객관적이고 적합한 성과 평가를 위해 전문가 여러분들의 의견을 수렴하고자 하오니 바쁘시더라도 각 설문의 내용 에 대해 성실히 응답해 주시면 감사하겠습니다.

※ 주관기관 : 문화체육관광부, 한국문화관광연구원

※ 담 당 자 : 양지훈 연구원(02-2669-6990, 010-5359-6568)

* 다음은 전문가 여러분들께서 모태펀드 문화계정 프로젝트 투자에 대한 성과평가 기준의 항목 중 어떠한 요소

를 중요하게 고려하는지를 파악하기 위한 설문입니다. 평가기준 항목은 다음과 같습니다.

\begin{tabular}{|c|c|c|c|c|}
\hline \multirow{2}{*}{ 구분 } & \multicolumn{2}{|c|}{ Enablers } & \multicolumn{2}{|c|}{ Results } \\
\hline & 투입(Input) & 과정(Process) & 산출(Output) & 결과(Outcome) \\
\hline 프로젝트 & $\begin{array}{l}\text { (1)목적투자 정도 } \\
\text { (2)만란즘유칯 노력 } \\
\text { (3)투자 프로젝트 규모 } \\
\text { (4)하라자본유치노력 }\end{array}$ & $\begin{array}{l}\text { (1)공모 투명성(개방성) } \\
\text { (2)프로젝트 지원 및 관리 } \\
\text { (3)과정 공정성 } \\
\text { (4)준법건전성 } \\
\text { (5지원의 시아성 }\end{array}$ & $\begin{array}{l}\text { (1)수익성 } \\
\text { (2)피투자처민족도 } \\
\text { (3)하외매출 } \\
\text { (4)화제성 }\end{array}$ & $\begin{array}{l}\text { (1)교용증가(m/h) } \\
\text { (2)산업육성기여 } \\
\text { (3)수악창출(comy) } \\
\text { (4)신업잡중도 } \\
\text { (5)국기브랜드제고 }\end{array}$ \\
\hline
\end{tabular}

각 지표를 분석하기 위해 중요 및 필요 요소라고 고려하는 항목을 중요도에 따라 표시해 주시기 바랍니다.

1. 문화계정의 프로젝트 투자에서 다음의 어느 항목이 얼마나 더 중요하다고 생각하십니까?

\begin{tabular}{|c|c|c|c|c|c|c|c|c|c|c|c|c|c|c|c|c|c|c|}
\hline & \begin{tabular}{|l|} 
궁히요 \\
\end{tabular} & & 매웅우 & & 중요 & & 야ㅈㅜㅜ앙ㅇ & & 동등 & & 야ㅈㅜㅜ안ㅇ & & 중요 & & 매우웅요 & & 극훙요 & \\
\hline A & \multicolumn{8}{|c|}{$\mathrm{A}$ 가 $\mathrm{B}$ 보다 중요 } & $=$ & \multicolumn{8}{|c|}{$\mathrm{B}$ 가 $\mathrm{A}$ 보다 중요 } & B \\
\hline $\begin{array}{c}\text { 투입 } \\
\text { [Input] }\end{array}$ & (9) & (8) & (7) & (6) & (5) & (4) & (3) & (2) & (1) & (2) & (3) & (4) & (5) & (6) & (7) & (8) & (9) & $\begin{array}{c}\text { 과정 } \\
\text { [Process] }\end{array}$ \\
\hline
\end{tabular}

\begin{tabular}{|c|c|c|c|c|c|c|c|c|c|c|c|c|c|c|c|c|c|c|}
\hline & \begin{tabular}{|l|} 
극힝요 \\
\end{tabular} & & 맹웅요 & & 중요 & & 야ㅈㅜㅜㅇ간 & & 동등 & & 약강욘 & & 중요 & & 매우웅요 & & 극훙요 & \\
\hline A & & & $A^{7}$ & & 다 중 & & & & $=$ & & & & $\mathrm{A}$ 보 & 다 끙 & & & & B \\
\hline $\begin{array}{c}\text { 투입 } \\
\text { [lnput] }\end{array}$ & (9) & (8) & (7) & (6) & (5) & (4) & (3) & (2) & (1) & (2) & (3) & (4) & (5) & (6) & (7) & (8) & (9) & $\begin{array}{c}\text { 산출 } \\
\text { [Output] }\end{array}$ \\
\hline
\end{tabular}




\begin{tabular}{|c|c|c|c|c|c|c|c|c|c|c|c|c|c|c|c|c|c|c|}
\hline & 극훙요 & & 매중우 & & 중요 & & 얒강요 & & 동등 & & 얒강앙 & & 중요 & & 매ㅇㅜㅜㅇㅇ & & 극힝요 & \\
\hline A & & & $A$ & I B보 & 다 & & & & $=$ & & & $B^{7}$ & A보 & 다 & & & & B \\
\hline $\begin{array}{c}\text { 투입 } \\
\text { [nput] }\end{array}$ & (9) & (8) & (7) & (6) & (5) & (4) & (3) & (2) & (1) & (2) & (3) & (4) & (5) & (6) & (7) & (8) & (9) & $\begin{array}{c}\text { 결과 } \\
\text { [Otcoome] }\end{array}$ \\
\hline
\end{tabular}

\begin{tabular}{|c|c|c|c|c|c|c|c|c|c|c|c|c|c|c|c|c|c|c|}
\hline & 극훙히 & & 매중우 & & 중요 & & 얒강요 & & 동등 & & 얒강강 & & 중요 & & 매중우 & & 긎훙이 & \\
\hline A & & & $A^{7}$ & B보 & 다 중 & 요 & & & $=$ & & & B기 & $\mathrm{A}$ 보 & 다 & 要 & & & B \\
\hline $\begin{array}{l}\text { 과정 } \\
\text { Process] }\end{array}$ & (9) & (8) & (7) & (6) & (5) & (4) & (3) & (2) & (1) & (2) & (3) & (4) & (5) & (6) & (7) & (8) & (9) & [산출 $[$ [Output] \\
\hline
\end{tabular}

\begin{tabular}{|c|c|c|c|c|c|c|c|c|c|c|c|c|c|c|c|c|c|c|}
\hline & 극힝요 & & 매중우 & & 중요 & & 약강요 & & 동등 & & 얒강간 & & 중요 & & 매ㅈㅜㅜㅇㅇㅇ & & 긎훙요 & \\
\hline A & & & $A$ & & 다 중 & 요 & & & $=$ & & & $B^{7}$ & $\mathrm{~A}$ 보 & 다 중 & 8 & & & B \\
\hline \begin{tabular}{|c|} 
과정 \\
[Process]
\end{tabular} & (9) & (8) & (7) & (6) & (5) & (4) & (3) & (2) & (1) & (2) & (3) & (4) & (5) & (6) & (7) & (8) & (9) & $\begin{array}{c}\text { 결과 } \\
\text { [OCoome }\end{array}$ \\
\hline
\end{tabular}

\begin{tabular}{|c|c|c|c|c|c|c|c|c|c|c|c|c|c|c|c|c|c|c|}
\hline & 긋항요 & & 매중우 & & 중요 & & 야중강 & & 동등 & & 야ㅈㅜㅜㅇ강 & & 중요 & & 맹웅요 & & 긋훙요 & \\
\hline A & & & A7 & & 다 중 & & & & $=$ & & & $B$ 기 & $\mathrm{A}$ 보 & 다 중 & 8 & & & B \\
\hline $\begin{array}{c}\text { 산출 } \\
\text { [Output] }\end{array}$ & (9) & (8) & (7) & (6) & (5) & (4) & (3) & (2) & (1) & (2) & (3) & (4) & (5) & (6) & (7) & (8) & (9) & $\begin{array}{c}\text { 결과 } \\
\text { [Otcome }\end{array}$ \\
\hline
\end{tabular}

2. 투입[Input]을 위한 평가항목 중 어느 항목이 얼마나 더 중요하다고 생각하십니까?

- 목적투자 정도: 목적투자비을, 목적투자 집행률 등 출자 시 설정한 목적에 투자한 정도

- 민간자금 유치노력: 신규LP개발, 민간비중 및 민간투자 확대, 평판높은 LP 유치 등 민간자금 투자확 대를 위한 노력 정도

- 투자 프로젝트 규모: 투자조합에서 투자를 진행한 프로젝트 건 수 등 그 규모

- 해외자본 유치 노력: 해외나 유치 등 해외 자본을 유치하기 위한 노력도

\begin{tabular}{|c|c|c|c|c|c|c|c|c|c|c|c|c|c|c|c|c|c|c|}
\hline & 긋훙요 & & 맹웅요 & & 중요 & & 얒강요 & & 동등 & & 얒궁교 & & 중요 & & 맹웅요 & & 긍힝요 & \\
\hline A & & & $A^{\top}$ & B보 & 다 중 & & & & $=$ & & & & A보 & 다 층 & & & & \\
\hline \begin{tabular}{|c|} 
목적투자 \\
정도
\end{tabular} & (9) & (8) & (7) & (6) & (5) & (4) & (3) & (2) & (1) & (2) & (3) & (4) & (5) & (6) & (7) & (8) & (9) & 민간자금 \\
\hline
\end{tabular}

\begin{tabular}{|c|c|c|c|c|c|c|c|c|c|c|c|c|c|c|c|c|c|c|}
\hline & 극힝요 & & 맹웅요 & & 중요 & & 양강앙 & & 동등 & & 얒강앙 & & 중요 & & 맹웅요 & & 긍힝요 & \\
\hline A & & & $A^{\top}$ & $B$ B & 다 줄 & 8 & & & $=$ & & & & A보 & 다 & 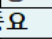 & & & \\
\hline $\begin{array}{l}\text { 목적투자 } \\
\text { 정도 }\end{array}$ & (9) & (8) & (7) & (6) & (5) & (4) & (3) & (2) & (1) & (2) & (3) & (4) & (5) & (b) & (7) & (8) & (9) & 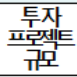 \\
\hline
\end{tabular}

\begin{tabular}{|c|c|c|c|c|c|c|c|c|c|c|c|c|c|c|c|c|c|c|}
\hline & 긎힝요 & & 맹웅요 & & 중요 & & 얒강 & & 동등 & & 야ㅈㅜㅜㅇ강 & & 중요 & & 맹웅우 & & 긎훙이 & \\
\hline A & & & $A^{7}$ & B토 & 다 중 & 요 & & & $=$ & & & Bᄀ & A보든 & 다 중 & 요 & & & B \\
\hline $\begin{array}{c}\text { 목적투자 } \\
\text { 정도 }\end{array}$ & (9) & (8) & (7) & (6) & (5) & (4) & (3) & (2) & (1) & (2) & (3) & (4) & (5) & (6) & (7) & (8) & (9) & $\begin{array}{l}\text { 해외자본 } \\
\text { 유치노력 }\end{array}$ \\
\hline
\end{tabular}




\begin{tabular}{|c|c|c|c|c|c|c|c|c|c|c|c|c|c|c|c|c|c|c|}
\hline & 극훙요 & & 매중웅 & & 중요 & & 야ㅈㅜㅜㅇ강 & & 동등 & & 야ㅈㅜㅜ앙ㅇ & & 중요 & & 매중우 & & 극훙요 & \\
\hline A & & & $A$ & & 다 중 & & & & $=$ & & & & $\mathrm{A}$ 보 & 다 & & & & B \\
\hline $\begin{array}{l}\text { 민간자금 } \\
\text { 유치노력 }\end{array}$ & (9) & (8) & (7) & (6) & (5) & (4) & (3) & (2) & (1) & (2) & (3) & (4) & (5) & (6) & (7) & (8) & (9) & $\begin{array}{l}\text { 투잠 } \\
\text { 파ㄱㅔㅔㅌㅌㅌ }\end{array}$ \\
\hline
\end{tabular}

\begin{tabular}{|c|c|c|c|c|c|c|c|c|c|c|c|c|c|c|c|c|c|c|}
\hline & 긍힝요 & & 맹웅ㅇ & & 중요 & & 얒궁긴 & & 동등 & & 얒강교 & & 중요 & & 맹웅요 & & 긍힝요 & \\
\hline A & & & & BE & 다 중 & & & & $=$ & & & & $\mathrm{A}$ 보 & 다 중 & & & & \\
\hline $\begin{array}{l}\text { 민간자금 } \\
\text { 유치노력 }\end{array}$ & (9) & (8) & (7) & (6) & (5) & (4) & (3) & (2) & (1) & (2) & (3) & (4) & (5) & (6) & (7) & (8) & (9) & $\begin{array}{l}\text { 해외자본 } \\
\text { 유치노력 }\end{array}$ \\
\hline
\end{tabular}

\begin{tabular}{|c|c|c|c|c|c|c|c|c|c|c|c|c|c|c|c|c|c|c|}
\hline & 긍훙요 & & 매중우 & & 중요 & & 얒강굥 & & 동등 & & 얒강요 & & 중요 & & 맹웅요 & & 긍힝요 & \\
\hline A & & & $A^{7}$ & BE & 다 중 & & & & $=$ & & & & $\mathrm{A}$ 보 & 다흘 & 8 & & & B \\
\hline 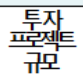 & (9) & (8) & (7) & (6) & (5) & (4) & (3) & (2) & (1) & (2) & (3) & (4) & (5) & (6) & (7) & (8) & (9) & $\begin{array}{l}\text { 해외자본 } \\
\text { 유치녹 }\end{array}$ \\
\hline
\end{tabular}

3. 과정 [Process]을 위한 평가항목 중 어느 항목이 얼마나 더 중요하다고 생각하십니까?

- 공모 투명성: 얼마나 개방적이고 투명하게 공모를 진행했는지 투자과정에서의 개방성 여부

- 프로젝트 지원 및 관리: 컨설팅, 비용관리 등 GP가 투자한 프로젝트에 대해 얼마나 지원했는지 정도 - 과정 공정성: 의사결정과정, 심사과정 등의 절차가 얼마나 공정했는지 여부

- 준법·건전성: 규약 및 법령위반 건 수 등 투자관리 상에서의 건전성 정도

- 지원의 시의성: 투자가 필요한 시점에서 이루어졌는지 여부

\begin{tabular}{|c|c|c|c|c|c|c|c|c|c|c|c|c|c|c|c|c|c|c|}
\hline & 긎힝요 & & 매중우 & & 중요 & & 야죽강 & & 동등 & & 얒강요 & & 중요 & & 매중우 & & 극힝요 & \\
\hline A & & & A 7 & B보 & 다 중 & 요 & & & $=$ & & & B7 & A보 & 다 릉 & 舟 & & & B \\
\hline $\begin{array}{c}\text { 공모 } \\
\text { 투명성 }\end{array}$ & (9) & (8) & (7) & (6) & (5) & (4) & (3) & (2) & (1) & (2) & (3) & (4) & (5) & (6) & (7) & (8) & (9) & 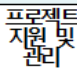 \\
\hline
\end{tabular}

\begin{tabular}{|c|c|c|c|c|c|c|c|c|c|c|c|c|c|c|c|c|c|c|}
\hline & 극훙요 & & 맹웅요 & & 중요 & & 얒궁강 & & 동등 & & 얒강간 & & 중요 & & 맹웅요 & & 극훙요 & \\
\hline A & & & & $B$ & 다 충 & & & & $=$ & \multicolumn{8}{|c|}{$\mathrm{B}$ 가 $\mathrm{A}$ 보다 중요 } & B \\
\hline $\begin{array}{l}\text { 공모 } \\
\text { 투명성 }\end{array}$ & (9) & (8) & (7) & (6) & (5) & (4) & (3) & (2) & (1) & (2) & (3) & (4) & (5) & (6) & (7) & (8) & (9) & $\begin{array}{c}\text { 과정 } \\
\text { 공정성 }\end{array}$ \\
\hline
\end{tabular}

\begin{tabular}{|c|c|c|c|c|c|c|c|c|c|c|c|c|c|c|c|c|c|c|}
\hline & 극훙요 & & 매중웅 & & 중요 & & 야ㅈㅜㅜㅇ간 & & 동등 & & 쟈ㅈㅜㅜㅇ강 & & 중요 & & 맹웅요 & & 그ㅈㅜㅜㅇㅎㅛ & \\
\hline A & & & A7 & $\mathrm{B}$ 보 & 다 중 & 8 & & & $=$ & & & B가 & A보 & 다 중 & 监 & & & B \\
\hline $\begin{array}{c}\text { 공모 } \\
\text { 투명성 }\end{array}$ & (9) & (8) & (7) & (6) & (5) & (4) & (3) & (2) & (1) & (2) & (3) & (4) & (5) & (6) & (7) & (8) & (9) & 준번선성 \\
\hline
\end{tabular}

\begin{tabular}{|c|c|c|c|c|c|c|c|c|c|c|c|c|c|c|c|c|c|c|}
\hline & 긍훙요 & & 맹웅요 & & 중요 & & 얒궁강요 & & 동등 & & 야중강 & & 중요 & & 맹웅요 & & 긍훙요 & \\
\hline A & & & $A^{7}$ & B! 도 & 다 중 & & & & $=$ & & & $B^{7}$ & $\mathrm{~A}$ 보 & 다흘 & 皿 & & & B \\
\hline $\begin{array}{c}\text { 공모 } \\
\text { 투명성 }\end{array}$ & (9) & (8) & (7) & (6) & (5) & (4) & (3) & (2) & (1) & (2) & (3) & (4) & (5) & (6) & (7) & (8) & (9) & 짓웡웡ㅇㅇ \\
\hline
\end{tabular}

\begin{tabular}{|c|c|c|c|c|c|c|c|c|c|c|c|c|c|c|c|c|c|c|}
\hline & 극훙요 & & 매중우 & & 중요 & & 야ㅈㅜㅜㅇ강 & & 동등 & & 야ㅈㅜㅜㅇㅏㅏㄴㅛ & & 중요 & & 매중우요 & & 극훙요 & \\
\hline A & & & $A^{2}$ & & 다 중 & & & & $=$ & & & $B^{7}$ & A보 & 다 중 & 8 & & & B \\
\hline 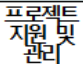 & (9) & (8) & (7) & (6) & (5) & (4) & (3) & (2) & (1) & (2) & (3) & (4) & (5) & (6) & (7) & (8) & (9) & $\begin{array}{c}\text { 과정 } \\
\text { 공정성 }\end{array}$ \\
\hline
\end{tabular}




\begin{tabular}{|c|c|c|c|c|c|c|c|c|c|c|c|c|c|c|c|c|c|c|}
\hline & 극훙요 & & 매중우 & & 중요 & & 얒강강 & & 동등 & & 야ㅈㅜㅜ앙요 & & 중요 & & 맹웅요 & & 그ㄱㅜㅜㅇㅇㅣ & \\
\hline A & & & $A^{7}$ & $B$ 토 & 다 중 & & & & $=$ & \multicolumn{8}{|c|}{$B$ 가 $A$ 보다 중요 } & B \\
\hline 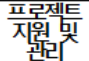 & (9) & (8) & (7) & (6) & (5) & (4) & (3) & (2) & (1) & (2) & (3) & (4) & (5) & (6) & (7) & (8) & (9) & 죽번선성 \\
\hline
\end{tabular}

\begin{tabular}{|c|c|c|c|c|c|c|c|c|c|c|c|c|c|c|c|c|c|c|}
\hline & ㄱㅡㅜ훙요 & & 매숭우 & & 중요 & & 얒궁강 & & 동등 & & 얒강용 & & 중요 & & 매중웅 & & ㄱㅡㅜ훙이 & \\
\hline A & & & $A^{\prime}$ & B 토 & 다 줄 & & & & $=$ & & & B가 & $\mathrm{A}$ 보 & 다 홍 & 监 & & & B \\
\hline 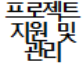 & (9) & (8) & (7) & (6) & (5) & (4) & (3) & (2) & (1) & (2) & (3) & (4) & (5) & (6) & (7) & (8) & (9) & 지숴워웟ㅇ \\
\hline
\end{tabular}

\begin{tabular}{|c|c|c|c|c|c|c|c|c|c|c|c|c|c|c|c|c|c|c|}
\hline & 긍훙요 & & 맹웅요 & & 중요 & & 얒강강 & & 동등 & & 얒강앙 & & 중요 & & 맹웅요 & & 긍훙요 & \\
\hline A & & & $A^{7}$ & & 다 중 & & & & $=$ & & & $B$ B기 & A보 & 다 중 & 皿 & & & B \\
\hline $\begin{array}{c}\text { 과정 } \\
\text { 공정성 }\end{array}$ & (9) & (8) & (7) & (6) & (5) & (4) & (3) & (2) & (1) & (2) & (3) & (4) & (5) & (6) & (7) & (8) & (9) & $\begin{array}{l}\text { 준법. } \\
\text { 건전성 }\end{array}$ \\
\hline
\end{tabular}

\begin{tabular}{|c|c|c|c|c|c|c|c|c|c|c|c|c|c|c|c|c|c|c|}
\hline & 극훙요 & & 맹웅요 & & 중요 & & 얒강앙 & & 동등 & & 얒강강 & & 중요 & & 맹중요 & & 극훙요 & \\
\hline A & & & $A^{7}$ & B토 & 다 중 & & & & $=$ & & & B기 & $\mathrm{A}$ 보 & 다 중 & 监 & & & B \\
\hline $\begin{array}{l}\text { 과정 } \\
\text { 공정성 }\end{array}$ & (9) & (8) & (7) & (6) & (5) & (4) & (3) & (2) & (1) & (2) & (3) & (4) & (5) & (6) & (7) & (8) & (9) & $\begin{array}{l}\text { 지원읭 } \\
\text { 싀성 }\end{array}$ \\
\hline
\end{tabular}

\begin{tabular}{|c|c|c|c|c|c|c|c|c|c|c|c|c|c|c|c|c|c|c|}
\hline & 긍훙요 & & 매수웅 & & 중요 & & 야ㅈㅜㅜㅇㅏㅏㅇ & & 동등 & & 얒궁앙 & & 중요 & & 매중요 & & 그ㄱㅜㅜㅇㅎㅛ & \\
\hline A & & & $A^{7}$ & & 다 중 & & & & $=$ & & & $B$ 기 & $\mathrm{A} ㅂ ㅗ$ & 단흘 & 줄요 & & & B \\
\hline 준번전성 & (9) & () & (7) & (6) & (5) & (4) & (3) & (2) & (1) & (2) & (3) & (4) & (5) & (6) & (7) & (8) & (9) & 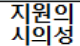 \\
\hline
\end{tabular}

\section{4. 산촐[Output]을 위한 평가항목 중 어느 항목이 얼마나 더 중요하다고 생각하십니까?}

- 수익성: IRR, 수익배수, PME 등 투자 수익성 정도

- 피투자처 만족도: 투자를 받은 프로젝트 및 문화전문회사에서의 만족도(설문조사)

- 해외매출: 해외 진출 매출액, 해외매출 비중 등 해외에서의 매출 정도

- 화제성: 언론 노출 정도, 수상실적 등 대외적 화제 정도

\begin{tabular}{|c|c|c|c|c|c|c|c|c|c|c|c|c|c|c|c|c|c|c|}
\hline & 극훙요 & & 매웅우 & & 중요 & & 얒강요 & & 동등 & & 쟞강요 & & 중요 & & 매ㅇㅜㅜㅇㅜ & & 긋훙요 & \\
\hline A & & & $A^{\top}$ & F B보 & 다 & & & & $=$ & & & & A보 & 다 & 要 & & & B \\
\hline 수익성 & (9) & (8) & (7) & (6) & (5) & (4) & (3) & (2) & (1) & (2) & (3) & (4) & (5) & (6) & (7) & (8) & (9) & $\begin{array}{l}\text { 피투자처 } \\
\text { 만족도 }\end{array}$ \\
\hline
\end{tabular}

\begin{tabular}{|c|c|c|c|c|c|c|c|c|c|c|c|c|c|c|c|c|c|c|}
\hline & 긋힝요 & & 매중우 & & 중요 & & 얒강요 & & 동등 & & |얒강안 & & 중요 & & 매ㅈㅜㅜ웅 & & 긎훙요 & \\
\hline A & & & $A^{\lambda}$ & B & 다 & & & & $=$ & & & B & $\mathrm{A}$ 보 & 다 & S요 & & & B \\
\hline 수익성 & (9) & (8) & (7) & (6) & (5) & (4) & (3) & (2) & (1) & (2) & (3) & (4) & (5) & (b) & (7) & (8) & (9) & 해외매출 \\
\hline
\end{tabular}

\begin{tabular}{|c|c|c|c|c|c|c|c|c|c|c|c|c|c|c|c|c|c|c|}
\hline & 극훙요 & & 매중웅 & & 중요 & & 쟈ㅈㅜㅜㅇㄱㅛ & & 동등 & & 얓궁굥 & & 중요 & & 맹웅요 & & 극훙요 & \\
\hline A & & & $A^{7}$ & BE & 다 줄 & & & & $=$ & & & & $\mathrm{A}$ 보 & 다 충 & & & & B \\
\hline 수익성 & (9) & (8) & (7) & (6) & (5) & (4) & (3) & (2) & (1) & (2) & (3) & (4) & (5) & (6) & (3) & () & (9) & 화제성 \\
\hline
\end{tabular}




\begin{tabular}{|c|c|c|c|c|c|c|c|c|c|c|c|c|c|c|c|c|c|c|}
\hline & 긎훙요 & & \begin{tabular}{|l|} 
맹웅ㅇ \\
\end{tabular} & & 중요 & & ㅇㅑㅜ궁강 & & 동등 & & 얒강강 & & 중요 & & 매숭웅 & & 긎훙요 & \\
\hline A & & & & $B$ 토 & 다 출 & & & & $=$ & & & $B$ 기 & A보 & 다 출 & 요 & & & B \\
\hline $\begin{array}{c}\text { 피두사서 } \\
\text { 만족도 }\end{array}$ & (9) & (8) & (7) & (6) & (5) & (4) & (3) & (2) & (1) & (2) & (3) & (4) & (5) & (6) & (7) & (8) & (9) & 해외매출 \\
\hline
\end{tabular}

\begin{tabular}{|c|c|c|c|c|c|c|c|c|c|c|c|c|c|c|c|c|c|c|}
\hline & 긍훙요 & & 매중우 & & 중요 & & 얒궁곤 & & 동등 & & 얓강항 & & 중요 & & 매중우 & & ㄱㅡㅜ힝요 & \\
\hline A & & & & B토 & 다 & & & & $=$ & & & & $\mathrm{A}$ 보 & 다 중 & 요 & & & B \\
\hline $\begin{array}{l}\text { 피투자처 } \\
\text { 만족도 }\end{array}$ & (9) & (8) & (7) & (6) & (5) & (4) & (3) & (2) & (1) & (2) & (3) & (4) & (5) & (6) & (7) & (8) & (9) & 화제성 \\
\hline
\end{tabular}

\begin{tabular}{|c|c|c|c|c|c|c|c|c|c|c|c|c|c|c|c|c|c|c|}
\hline & 긍훙요 & & 맹웅우 & & 중요 & & 얒궁강 & & 동등 & & 얒궁교 & & 중요 & & 매웅웅 & & 극훙요 & \\
\hline A & & & $A^{7}$ & & 다 줄 & 8 & & & $=$ & & & B7 & A보 & 다 중 & 5.8 & & & B \\
\hline 해외매출 & (9) & (8) & (7) & (6) & (5) & (4) & (3) & (2) & (1) & (2) & (3) & (4) & (5) & (6) & (7) & () & (9) & 화제성 \\
\hline
\end{tabular}

5. 결과[Outcome]을 위한 평가항목 중 어느 항목이 얼마나 더 중요하다고 생각하십니까?

- 고용증가: 투자를 통해 나타난 고용의 증가 정도

- 산업육성기여: 해당 산업의 매출액, 수출액 증대 등 해당 분야의 산업발전 기여 정도

- IP(OSMU)수익 창출: 투자한 프로젝트에서 창출한 IP수익 정도(웹툰의 영화화 등)

- 산업분산도: 투자포트폴리오의 산업분산 정도

(다양한 분야, 장르, 규모 등 다양하게 투자될 경우 높은 점수)

- 국가브랜드제고: 투자한 기업의 성과를 통한 한류 및 국가 브랜드 제고 정도

\begin{tabular}{|c|c|c|c|c|c|c|c|c|c|c|c|c|c|c|c|c|c|c|}
\hline & 긍훙요 & & 매중우 & & 중요 & & 얒궁간 & & 동등 & & 쟈ㅈㅜㅜㅇ강 & & 중요 & & 매수웅 & & 극힝요 & \\
\hline A & & & $A^{\top}$ & & 다 중 & & & & $=$ & & & $B^{7}$ & A보 & 다 출 & 요 & & & B \\
\hline 고용증가 & (9) & (8) & (7) & (6) & (5) & (4) & (3) & (2) & (1) & (2) & (3) & (4) & (5) & (6) & (7) & (8) & (9) & 산업융성 \\
\hline
\end{tabular}

\begin{tabular}{|c|c|c|c|c|c|c|c|c|c|c|c|c|c|c|c|c|c|c|}
\hline & 극훙요 & & 매ㅇㅜㅜㅇㅇㅛ & & 중요 & & 야ㅈㅜㅜㅇ간 & & 동등 & & 야ㅈㅜㅜ앙 & & 중요 & & 매웅우 & & 긍훙요 & \\
\hline A & & & $A^{\lambda}$ & & 다 중 & 요 & & & $=$ & & & $B^{7}$ & A보 & 다 츨 & 요 & & & B \\
\hline 고용증가 & (9) & (8) & (7) & (6) & (5) & (4) & (3) & (2) & (1) & (2) & (3) & (4) & (5) & (6) & (7) & (8) & (9) & $\begin{array}{l}\text { IP(OSMU } \\
\text { 수익창출 }\end{array}$ \\
\hline
\end{tabular}

\begin{tabular}{|c|c|c|c|c|c|c|c|c|c|c|c|c|c|c|c|c|c|c|}
\hline & 긍힝요 & & 매중우 & & 중요 & & \begin{tabular}{|l|} 
양강 \\
\end{tabular} & & 동등 & & 얒강용 & & 중요 & & 매우웅 & & ㄱㅡㅜ힝요 & \\
\hline A & & & $A^{7}$ & & 다 중 & 요 & & & $=$ & & & $B^{7}$ & A보 & 다 출 & s.8 & & & B \\
\hline 고용증가 & (9) & (8) & (7) & (6) & (5) & (4) & (3) & (2) & (1) & (2) & (3) & (4) & (5) & (6) & (7) & (8) & (9) & 산선언도 \\
\hline
\end{tabular}

\begin{tabular}{|c|c|c|c|c|c|c|c|c|c|c|c|c|c|c|c|c|c|c|}
\hline & 극훙이 & & 맹웅우 & & 중요 & & 야ㅈㅜㅜㅇ강 & & 동등 & & 야ㅈㅜㅜㅇ강 & & 중요 & & 매우우 & & 그ㅈㅜㅜㅇㅇㅣ & \\
\hline A & & & $\mathrm{A}^{2}$ & B보 & 다 중 & & & & $=$ & & & BD & $A$ 보 & 다 중 & 5 & & & B \\
\hline 고용증가 & (9) & (8) & (7) & (6) & (5) & (4) & (3) & (2) & (1) & (2) & (3) & (4) & (5) & (6) & (7) & (8) & (9) & 브ㄹㅐㅐ태트 \\
\hline
\end{tabular}

\begin{tabular}{|c|c|c|c|c|c|c|c|c|c|c|c|c|c|c|c|c|c|c|}
\hline & 긍힝요 & & 맹웅요 & & 중요 & & 얒강강 & & 동등 & & 얒강뇨 & & 중요 & & 매중우 & & 극힝요 & \\
\hline A & & & $A^{7}$ & & 다 중 & 8 & & & $=$ & & & $B^{7}$ & A보 & 다 & 要 & & & B \\
\hline 산업육성 & (9) & (8) & (7) & (6) & (5) & (4) & (3) & (2) & (1) & (2) & (3) & (4) & (5) & (6) & (7) & (8) & (9) & $\begin{array}{l}\text { IP(OSMU } \\
\text { 수익창출 }\end{array}$ \\
\hline
\end{tabular}




\begin{tabular}{|c|c|c|c|c|c|c|c|c|c|c|c|c|c|c|c|c|c|c|}
\hline & 극훙요 & & 맹웅요 & & 중요 & & 얒강요 & & 동등 & & 얒강요 & & 중요 & & 맹웅요 & & 극훙요 & \\
\hline A & & & $A^{2}$ & B토 & 다 중 & 8 & & & $=$ & & & B & A보 & 다 흘 & 监 & & & B \\
\hline 산업육셔엉 & (9) & (8) & (7) & (6) & (5) & (4) & (3) & (2) & (1) & (2) & (3) & (4) & (5) & (6) & (7) & (8) & (9) & 산업산도 \\
\hline
\end{tabular}

\begin{tabular}{|c|c|c|c|c|c|c|c|c|c|c|c|c|c|c|c|c|c|c|}
\hline & 극힝요 & & 매중우 & & 중요 & & 얓궁잉 & & 동등 & & 얒강강 & & 중요 & & 맹웅요 & & 극힝요 & \\
\hline A & & & $A^{7}$ & BE & 다 & & & & $=$ & & & & A보 & 다 & & & & B \\
\hline 산업육성 & (9) & (8) & (7) & (6) & (5) & (4) & (3) & (2) & (1) & (2) & (3) & (4) & (5) & (B) & (7) & (8) & (9) & 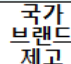 \\
\hline
\end{tabular}

\begin{tabular}{|c|c|c|c|c|c|c|c|c|c|c|c|c|c|c|c|c|c|c|}
\hline & ㄱㅡㅜ힝요 & & 맹웅 & & 중요 & & 얒강용 & & 동등 & & 얒강요 & & 중요 & & 매중우 & & ㄱㅡㅜ힝요 & \\
\hline A & & & & B! & 다 중 & & & & $=$ & & & & $\mathrm{A}$ & 다 릉 & & & & B \\
\hline $\begin{array}{l}\text { IP(OSMUU } \\
\text { 수익창출 }\end{array}$ & (9) & (8) & (7) & (6) & (5) & (4) & (3) & (2) & (1) & (2) & (3) & (4) & (5) & (6) & (7) & (8) & (9) & 산업 \\
\hline
\end{tabular}

\begin{tabular}{|c|c|c|c|c|c|c|c|c|c|c|c|c|c|c|c|c|c|c|}
\hline & 극훙요 & & 매숭우 & & 중요 & & 쟈ㅈㅜㅜㅇㄱㅛ & & 동등 & & 쟞궁요 & & 중요 & & 매ㅇㅜㅜㅇㅜ & & 긋훙요 & \\
\hline A & & & $A^{2}$ & B! 토 & 다 중 & & & & $=$ & & & $B^{7}$ & $\mathrm{~A}$ 보 & 다 출 & 8 & & & B \\
\hline $\begin{array}{l}\text { IP(OSMMU } \\
\text { 수익창출 }\end{array}$ & (9) & (8) & (7) & (6) & (5) & (4) & (3) & (2) & (1) & (2) & (3) & (4) & (5) & (6) & (7) & (8) & (9) & $\begin{array}{l}\text { 굴ㄱㅏㅐㄷㅡ 블 } \\
\text { 젝 }\end{array}$ \\
\hline
\end{tabular}

\begin{tabular}{|c|c|c|c|c|c|c|c|c|c|c|c|c|c|c|c|c|c|c|}
\hline & 극힝요 & & 매ㅈㅜㅜㅇㅜ & & 중요 & & 얒강용 & & 동등 & & 얒강효 & & 중요 & & 맹웅요 & & 극훙요 & \\
\hline A & & & $A^{7}$ & & 다 & & & & $=$ & & & & $\mathrm{A}$ 보 & 다 & 要 & & & \\
\hline 산안언도 & (9) & (8) & (7) & (6) & (5) & (4) & (3) & (2) & (1) & (2) & (3) & (4) & (5) & (6) & (7) & (8) & (9) & 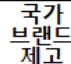 \\
\hline
\end{tabular}




\begin{tabular}{|c|c|c|c|c|}
\hline \multirow{2}{*}{ 구분 } & \multicolumn{2}{|c|}{ Enablers } & \multicolumn{2}{|c|}{ Results } \\
\hline & 투입(Input) & 과정(Process) & 산훌(Output) & 결과(Outcome) \\
\hline 기업 & $\begin{array}{l}\text { (1)목적투자 정도 } \\
\text { (2)민간자금 유치 노력 } \\
\text { (3)투자 기업 규모(수) } \\
\text { (4)해외자본 유치노력 } \\
\text { (5이투자처 풀확장 노력 }\end{array}$ & $\begin{array}{l}\text { (1)공모 투명성(개방성) } \\
\text { (2)피투자기업 지원 및 관리 } \\
\text { (3)과정 공정성 } \\
\text { (4)준법·건전성 }\end{array}$ & $\begin{array}{l}\text { (1)수익성 } \\
\text { (2)피투자기업만족도 } \\
\text { (3)해외매출 }\end{array}$ & $\begin{array}{l}\text { (1)고용증가(m/h) } \\
\text { (2)산업육성기여 } \\
\text { (3)P수익창출(OSMU) } \\
\text { (4)투자기업성장성 } \\
\text { (5)쌩존율 } \\
\text { (6)산업분산도 } \\
\text { (7)국가브랜드제고 }\end{array}$ \\
\hline
\end{tabular}

각 지표를 분석하기 위해 중요 및 필요 요소라고 고려하는 항목을 중요도에 따라 표시해 주시기 바랍니다.

1. 문화계정의 기업투자에서 다음의 어느 항목이 얼마나 더 중요하다고 생각하십니까?

\begin{tabular}{|c|c|c|c|c|c|c|c|c|c|c|c|c|c|c|c|c|c|c|}
\hline & $\begin{array}{l}\text { 극히잉요 } \\
\end{array}$ & & \begin{tabular}{|l|} 
매웅우 \\
\end{tabular} & & 중요 & & 얒궁간 & & 동등 & & 얒궁간 & & 중요 & & 매웅 & & $\begin{array}{l}\text { 극히 } \\
\text { 중요 }\end{array}$ & \\
\hline A & & & $A^{7}$ & B도 & 다 중 & & & & $=$ & \multicolumn{8}{|c|}{$\mathrm{B}$ 가 $\mathrm{A}$ 보다 중요 } & B \\
\hline $\begin{array}{c}\text { 투입 } \\
\text { [Input] }\end{array}$ & (9) & (8) & (7) & (6) & (5) & (4) & (3) & (2) & (1) & (2) & (3) & (4) & (5) & (6) & (7) & (8) & (9) & $\begin{array}{c}\text { 과정 } \\
\text { [Process] }\end{array}$ \\
\hline
\end{tabular}

\begin{tabular}{|c|c|c|c|c|c|c|c|c|c|c|c|c|c|c|c|c|c|c|}
\hline & 극훙요 & & \begin{tabular}{|l|} 
매웅우 \\
\end{tabular} & & 중요 & & 얒궁간 & & 동등 & & 얒궁간 & & 중요 & & $\begin{array}{l}\text { 매웅 } \\
\text { 중요 }\end{array}$ & & $\begin{array}{l}\text { 긎히이 } \\
\text { 중요 }\end{array}$ & \\
\hline A & & & $A^{7}$ & B토 & 다 출 & & & & $=$ & & & & $\mathrm{A}$ 보 & 다 & 요 & & & B \\
\hline $\begin{array}{c}\text { 투입 } \\
\text { [Input] }\end{array}$ & (9) & (8) & (7) & (6) & (5) & (4) & (3) & (2) & (1) & (2) & (3) & (4) & (5) & (6) & (7) & (8) & (9) & $\begin{array}{c}\text { 산출 } \\
\text { [Output] }\end{array}$ \\
\hline
\end{tabular}

\begin{tabular}{|c|c|c|c|c|c|c|c|c|c|c|c|c|c|c|c|c|c|c|}
\hline & $\begin{array}{l}\text { 긎히 } \\
\text { 중요 }\end{array}$ & & $\begin{array}{l}\text { 매우 } \\
\text { 중요 }\end{array}$ & & 중요 & & 얒강간 & & 동등 & & 얒궁간 & & 중요 & & $\begin{array}{l}\text { 매웅 } \\
\text { 중요 }\end{array}$ & & \begin{tabular}{|l|} 
극훙요 \\
\end{tabular} & \\
\hline$A$ & \multicolumn{8}{|c|}{$\mathrm{A}$ 가 $\mathrm{B}$ 보다 중요 } & $=$ & \multicolumn{8}{|c|}{ B가 A보다 중요 } & B \\
\hline $\begin{array}{c}\text { 투입 } \\
\text { [Input] }\end{array}$ & (9) & (8) & (7) & (6) & (5) & (4) & (3) & (2) & (1) & (2) & (3) & (4) & (5) & (6) & (7) & (8) & (9) & $\begin{array}{c}\text { 결과 } \\
\text { [Outoome }\end{array}$ \\
\hline
\end{tabular}

\begin{tabular}{|c|c|c|c|c|c|c|c|c|c|c|c|c|c|c|c|c|c|c|}
\hline & 그ㄱㅜㅜㅇㅇㅛ & & 매중우 & & 중요 & & 얒궁욘 & & 동등 & & 얒궁간 & & 중요 & & 매중우 & & \begin{tabular}{|l|} 
궁힝요 \\
\end{tabular} & \\
\hline A & \multicolumn{8}{|c|}{$\mathrm{A}$ 가 $\mathrm{B}$ 보다 중요 } & $=$ & \multicolumn{8}{|c|}{ B가 A보다 중요 } & B \\
\hline \begin{tabular}{|c|} 
과정 \\
[Process]
\end{tabular} & (9) & (8) & (7) & (6) & (5) & (4) & (3) & (2) & (1) & (2) & (3) & (4) & (5) & (6) & (7) & (8) & (9) & $\begin{array}{c}\text { 산출 } \\
\text { [Output] }\end{array}$ \\
\hline
\end{tabular}

\begin{tabular}{|c|c|c|c|c|c|c|c|c|c|c|c|c|c|c|c|c|c|c|}
\hline & 극힝요 & & 매우웅ㅇ & & 중요 & & 얒궁간 & & 동등 & & 양궁간 & & 중요 & & 매우웅 & & \begin{tabular}{|l|} 
극훙요 \\
\end{tabular} & \\
\hline A & & & & B토 & 다 중 & & & & $=$ & & & B) & $\mathrm{A}$ 보 & 다 & 요 & & & B \\
\hline [과정 & (9) & (8) & (7) & (6) & (5) & (4) & (3) & (2) & (1) & (2) & (3) & (4) & (5) & (6) & (7) & (8) & (9) & $\begin{array}{c}\text { 결과 } \\
\text { [OCtoome] }\end{array}$ \\
\hline
\end{tabular}




\begin{tabular}{|c|c|c|c|c|c|c|c|c|c|c|c|c|c|c|c|c|c|c|}
\hline & 긍힝요 & & $\begin{array}{l}\text { 매중우 } \\
\end{array}$ & & 중요 & & 얒강용 & & 동등 & & 얒강효 & & 중요 & & 매중우 & & \begin{tabular}{|l} 
긍히요 \\
\end{tabular} & \\
\hline A & & & $A^{7}$ & BE & 다 중 & 요 & & & $=$ & & & $B^{7}$ & $\mathrm{~A}$ 보 & 다 & 요 & & & B \\
\hline $\begin{array}{c}\text { 산출 } \\
\text { [Output] }\end{array}$ & (9) & (8) & (7) & (6) & (5) & (4) & (3) & (2) & (1) & (2) & (3) & (4) & (5) & (6) & (7) & (8) & (9) & $\begin{array}{c}\text { 결과 } \\
\text { [atcoome }\end{array}$ \\
\hline
\end{tabular}

2. 투입[Input]을 위한 평가항목 중 어느 항목이 얼마나 더 중요하다고 생각하십니까?

- 목적투자 정도: 목적투자비율, 목적투자 집행률 등 출자 시 설정한 목적에 투자한 정도

- 민간자금 유치노력: 신규LP개발, 민간비중 및 민간투자 확대, 평판높은 LP 유치 등 민간자금 투자확 대를 위한 노력 정도

- 투자 기업 규모(수): 투자조합에서 투자를 진행한 기업 건 수 등 그 규모

해외자본 유치 노력: 해외LP 유치 등 해외 자본을 유치하기 위한 노력 정도

피투자처 풀확장 노력: 새로운 기업 발굴을 위한 피투자처 풀확장 노력 정도

\begin{tabular}{|c|c|c|c|c|c|c|c|c|c|c|c|c|c|c|c|c|c|c|}
\hline & 극힝요 & & 매중우 & & 중요 & & 야ㅈㅜㅏ안ㅇ & & 동등 & & 얒궁깅 & & 중요 & & 매중요 & & 긋항요 & \\
\hline A & & & $A^{\prime}$ & B보 & 다 출 & & & & $=$ & & & & $\mathrm{A}$ 보 & 다 & 요 & & & B \\
\hline $\begin{array}{l}\text { 목적투자 } \\
\text { 정도 }\end{array}$ & (9) & (8) & (7) & (6) & (5) & (4) & (3) & (2) & (1) & (2) & (3) & (4) & (5) & (6) & (ㄱ) & (8) & (9) & 민간자그믐 유소력 \\
\hline
\end{tabular}

\begin{tabular}{|c|c|c|c|c|c|c|c|c|c|c|c|c|c|c|c|c|c|c|}
\hline & 긋훙요 & & 매중요 & & 중요 & & 얒궁교 & & 동등 & & 야ㅈㅜㅜㅇ강 & & 중요 & & 매중우 & & 긎훙요 & \\
\hline A & & & $A^{\prime}$ & I B토 & 다 출 & 요 & & & $=$ & & & & A보 & 다 & & & & B \\
\hline $\begin{array}{l}\text { 목적투자 } \\
\text { 정도 }\end{array}$ & (9) & (8) & (7) & (6) & (5) & (4) & (3) & (2) & (1) & (2) & (3) & (4) & (5) & (6) & (7) & (8) & (9) & $\begin{array}{c}\text { 투자 } \\
\text { 기업규모 }\end{array}$ \\
\hline
\end{tabular}

\begin{tabular}{|c|c|c|c|c|c|c|c|c|c|c|c|c|c|c|c|c|c|c|}
\hline & 긋훙요 & & 매중ㅇㅇㅇ & & 중요 & & 얒강욘 & & 동등 & & 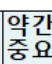 & & 중요 & & 매중웅 & & 긍훙요 & \\
\hline A & & & $A^{2}$ & & 다 중 & 8 & & & $=$ & & & $B 7$ & A보 & 다 & 요 & & & B \\
\hline $\begin{array}{l}\text { 목적투자 } \\
\text { 정도 }\end{array}$ & (9) & (8) & (7) & (6) & (5) & (4) & (3) & (2) & (1) & (2) & (3) & (4) & (5) & (6) & (7) & (8) & (9) & 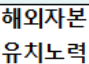 \\
\hline
\end{tabular}

\begin{tabular}{|c|c|c|c|c|c|c|c|c|c|c|c|c|c|c|c|c|c|c|}
\hline & 긍힝요 & & 맹중요 & & 중요 & & 야ㅈㅜㅜㅇ강 & & 동등 & & 야ㅈㅜㅜㅇ강 & & 중요 & & 매중우 & & 긍힝요 & \\
\hline A & & & $A^{\top}$ & B & 다 충 & 8 & & & $=$ & & & $B 7$ & A보 & 다 중 & 요 & & & B \\
\hline $\begin{array}{l}\text { 목적투자 } \\
\text { 정도 }\end{array}$ & (9) & (8) & (7) & (6) & (5) & (4) & (3) & (2) & (1) & (2) & (3) & (4) & (5) & (6) & (7) & (8) & (9) & 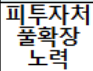 \\
\hline
\end{tabular}

\begin{tabular}{|c|c|c|c|c|c|c|c|c|c|c|c|c|c|c|c|c|c|c|}
\hline & 극훙요 & & 매중요 & & 중요 & & 야ㅈㅜㅜㅇ간 & & 동등 & & 야ㅈㅜㅜㅇ강 & & 중요 & & 매웅우 & & |극훙요 & \\
\hline A & & & $A^{7}$ & & 다 중 & 요 & & & $=$ & & & BD & A보 & 다 줄 & 5.8 & & & B \\
\hline $\begin{array}{l}\text { 민간자금 } \\
\text { 유치노력 }\end{array}$ & (9) & (8) & (7) & (6) & (5) & (4) & (3) & (2) & (1) & (2) & (3) & (4) & (5) & (6) & (7) & (8) & (9) & $\begin{array}{c}\text { 투자 } \\
\text { 기업규모 }\end{array}$ \\
\hline
\end{tabular}

\begin{tabular}{|c|c|c|c|c|c|c|c|c|c|c|c|c|c|c|c|c|c|c|}
\hline & 극훙요 & & 매ㅇㅜㅜㅇㅜ & & 중요 & & 쟞강아 & & 동등 & & 얒궁강 & & 중요 & & \begin{tabular}{|l|} 
맹웅ㅇ \\
\end{tabular} & & \begin{tabular}{|l|} 
궁힝ㅇ \\
\end{tabular} & \\
\hline A & & & $A^{\top}$ & & 다 중 & 요 & & & $=$ & & & BD & A보 & 다 & 요 & & & B \\
\hline $\begin{array}{l}\text { 민간자금 } \\
\text { 유치노력 }\end{array}$ & (9) & (8) & (7) & (6) & (5) & (4) & (3) & (2) & (1) & (2) & (3) & (4) & (5) & (6) & (7) & (8) & (9) & 해외자본 \\
\hline
\end{tabular}




\begin{tabular}{|c|c|c|c|c|c|c|c|c|c|c|c|c|c|c|c|c|c|c|}
\hline & 긎힝요 & & 맹웅요 & & 중요 & & 얒궁교 & & 동등 & & 얒강요 & & 중요 & & 맹웅요 & & 굿훙요 & \\
\hline A & & & $A^{7}$ & B토 & 다 중 & & & & $=$ & & & B가 & A보 & 다 & 8 & & & B \\
\hline $\begin{array}{l}\text { 민간자금 } \\
\text { 유치노력 }\end{array}$ & (9) & (8) & (7) & (6) & (5) & (4) & (3) & (2) & (1) & (2) & (3) & (4) & (5) & (6) & (7) & (8) & (9) & $\begin{array}{l}\text { 피투타ㅈㅓㅓ } \\
\text { 훌환장 }\end{array}$ \\
\hline
\end{tabular}

\begin{tabular}{|c|c|c|c|c|c|c|c|c|c|c|c|c|c|c|c|c|c|c|}
\hline & \begin{tabular}{|c} 
긍힝이 \\
\end{tabular} & & 맹웅요 & & 중요 & & 얒강강 & & 동등 & & 얒강강 & & 중요 & & \begin{tabular}{|l|} 
매웅 \\
웅
\end{tabular} & & 긍힝요 & \\
\hline A & & & $A^{7}$ & B! & 다 중 & 8 & & & $=$ & & & $B 7$ & A보 & 다 중 & 요 & & & \\
\hline $\begin{array}{c}\text { 투자 } \\
\text { 기업규모 }\end{array}$ & (9) & (8) & (7) & (6) & (5) & (4) & (3) & (2) & (1) & (2) & (3) & (4) & (5) & (6) & (7) & (8) & (9) & $\begin{array}{l}\text { 해외자본 } \\
\text { 유치노력 }\end{array}$ \\
\hline
\end{tabular}

\begin{tabular}{|c|c|c|c|c|c|c|c|c|c|c|c|c|c|c|c|c|c|c|}
\hline & 글훙효 & & 매중우 & & 중요 & & 야ㅈㅜㅜㅇ강 & & 동등 & & 야중강요 & & 중요 & & 맹웅요 & & 극궁요 & \\
\hline A & & & $A^{\prime}$ & B 토 & 다 중 & 요 & & & $=$ & & & BD & A보 & 다 중 & 요 & & & B \\
\hline $\begin{array}{c}\text { 투자 } \\
\text { 기업규모 }\end{array}$ & (9) & (8) & (7) & (6) & (5) & (4) & (3) & (2) & (1) & (2) & (3) & (4) & (5) & (6) & (7) & (8) & (9) & 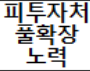 \\
\hline
\end{tabular}

\begin{tabular}{|c|c|c|c|c|c|c|c|c|c|c|c|c|c|c|c|c|c|c|}
\hline & 극훙요 & & 매중우 & & 중요 & & 쟈ㅈㅜㅜㅇ간 & & 동등 & & 쟈ㅈㅜㅜㅇ강 & & 중요 & & 맹중우 & & |궁힝요 & \\
\hline A & & & $A^{\top}$ & B! & 다 중 & & & & $=$ & & & $B^{2}$ & $\mathrm{~A}$ 보 & 다 홍 & 8 & & & B \\
\hline $\begin{array}{l}\text { 해외자본 } \\
\text { 유치노력 }\end{array}$ & (9) & (8) & (7) & (6) & (5) & (4) & (3) & (2) & (1) & (2) & (3) & (4) & (5) & (6) & (7) & (8) & (9) & $\begin{array}{l}\text { 피투잧처 } \\
\text { 훌확장 }\end{array}$ \\
\hline
\end{tabular}

\section{3. 과정[Process]을 위한 평가항목 중 어느 항목이 얼마나 더 중요하다고 생각하십니까?}

- 공모 투명성: 얼마나 개방적이고 투명하게 공모를 진행했는지 투자과정에서의 개방성 여부

- 피투자기업 지원 및 관리: 컨설팅, 비용관리 등 GP가 투자한 기업에 대해 얼마나 지원했는지 정도

- 과정 공정성: 의사결정과정, 심사과정 등의 절차가 얼마나 공정했는지 여부

- 준법·건전성: 규약 및 법령위반 건 수 등 투자관리상에서의 건전성 정도

\begin{tabular}{|c|c|c|c|c|c|c|c|c|c|c|c|c|c|c|c|c|c|c|}
\hline & 그ㄱㅜㅜㅇㅇㅛ & & 매ㅈㅜㅜㅇㅇㅜ & & 중요 & & 야ㅈㅜㅜㅇ굥 & & 동등 & & 얒강용 & & 중요 & & 매중웅 & & 극훙요 & \\
\hline A & & & $A^{2}$ & & 다 충 & 8 & & & $=$ & & & B기 & A보 & 다 & 要 & & & B \\
\hline $\begin{array}{l}\text { 공모 } \\
\text { 투명성 }\end{array}$ & (9) & (8) & (7) & (6) & (5) & (4) & (3) & (2) & (1) & (2) & (3) & (4) & (5) & (6) & (7) & (8) & (9) & 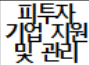 \\
\hline
\end{tabular}

\begin{tabular}{|c|c|c|c|c|c|c|c|c|c|c|c|c|c|c|c|c|c|c|}
\hline & 극힝요 & & 매중요 & & 중요 & & 얒궁굥 & & 동등 & & 얒강앙 & & 중요 & & 맹웅요 & & 극훙요 & \\
\hline A & & & & $B$ & 다 를 & & & & $=$ & \multicolumn{8}{|c|}{$B$ 가 A보다 중요 } & B \\
\hline $\begin{array}{c}\text { 공모 } \\
\text { 투명성 }\end{array}$ & (9) & (8) & (7) & (6) & (5) & (4) & (3) & (2) & (1) & (2) & (3) & (4) & (5) & (b) & (ㄱ) & (8) & (9) & $\begin{array}{l}\text { 과정 } \\
\text { 공정성 }\end{array}$ \\
\hline
\end{tabular}

\begin{tabular}{|c|c|c|c|c|c|c|c|c|c|c|c|c|c|c|c|c|c|c|}
\hline & \begin{tabular}{|l} 
긍힝요 \\
\end{tabular} & & 매중우 & & 중요 & & 얒강간 & & 동등 & & 얒강안 & & 중요 & & 맹웅요 & & 긍힝요 & \\
\hline A & & & $A$ & F B보 & 다 출 & & & & $=$ & & & $B 7$ & $A$ 보 & 다 & 要 & & & B \\
\hline $\begin{array}{l}\text { 공모 } \\
\text { 투명성 }\end{array}$ & (9) & (8) & (7) & (6) & (5) & (4) & (3) & (2) & (1) & (2) & (3) & (4) & (5) & (b) & (7) & (8) & (9) & 준번선성 \\
\hline
\end{tabular}

\begin{tabular}{|c|c|c|c|c|c|c|c|c|c|c|c|c|c|c|c|c|c|c|}
\hline & 그ㄱㅜㅜㅇㅇㅇ & & 매숭우 & & 중요 & & 야ㅈㅜㅜㅇ강 & & 동등 & & 야ㅈㅜㅜ앙요 & & 중요 & & 맹웅우 & & 그ㅈㅜㅜㅇㅇㅛ & \\
\hline A & & & $A^{7}$ & & 다 중 & 8 & & & $=$ & & & $B^{7}$ & $\mathrm{~A}$ 보 & 장 중 & 8 & & & B \\
\hline 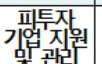 & (9) & (8) & (7) & (6) & (5) & (4) & (3) & (2) & (1) & (2) & (3) & (4) & (5) & (6) & (7) & (8) & (9) & $\begin{array}{l}\text { 과정 } \\
\text { 공정성 }\end{array}$ \\
\hline
\end{tabular}




\begin{tabular}{|c|c|c|c|c|c|c|c|c|c|c|c|c|c|c|c|c|c|c|}
\hline & 극힝요 & & 매중우 & & 중요 & & 얒강강 & & 동등 & & 얒강강 & & 중요 & & 매중우 & & \begin{tabular}{|c} 
긍힝요 \\
\end{tabular} & \\
\hline A & & & A & & 다 중 & & & & $=$ & & & & $\mathrm{A}$ 보 & 다 중 & 5요 & & & B \\
\hline $\begin{array}{l}\text { 피엄자ㅇㅝㅝ } \\
\text { 및 좐리 }\end{array}$ & (9) & (8) & (7) & (6) & (5) & (4) & (3) & (2) & (1) & (2) & (3) & (4) & (5) & (6) & (7) & (8) & (9) & 준번선성 \\
\hline
\end{tabular}

\begin{tabular}{|c|c|c|c|c|c|c|c|c|c|c|c|c|c|c|c|c|c|c|}
\hline & 긍훙요 & & 맹웅요 & & 중요 & & 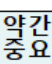 & & 동등 & & 얒강간 & & 중요 & & 매ㅈㅜㅜㅇㅇㅛ & & 긍힝요 & \\
\hline A & & & $A^{\top}$ & & 다 중 & & & & $=$ & \multicolumn{8}{|c|}{$\mathrm{B}$ 가 $\mathrm{A}$ 보다 중요 } & B \\
\hline $\begin{array}{l}\text { 과정 } \\
\text { 공정성 }\end{array}$ & (9) & (8) & (7) & (6) & (5) & (4) & (3) & (2) & (1) & (2) & (3) & (4) & (5) & (6) & (7) & (8) & (9) & 준번선성 \\
\hline
\end{tabular}

4. 산촐[Output]을 위한 평가항목 중 어느 항목이 얼마나 더 중요하다고 생각하십니까?

- 수익성: IRR, 수익배수, PME 등 투자 수익성 정도

- 피투자기업 만족도: 투자를 받은 기업에서의 만족도(설문조사)

- 해외매출: 해외 진출 매출액, 해외매출 비중 등 해외에서의 매출 정도

\begin{tabular}{|c|c|c|c|c|c|c|c|c|c|c|c|c|c|c|c|c|c|c|}
\hline & 극훙요 & & 매중우 & & 중요 & & 야ㅈㅜㅜㅇ간 & & 동등 & & 얒궁간 & & 중요 & & 매중우 & & \begin{tabular}{|l|} 
극훙이 \\
\end{tabular} & \\
\hline A & & & & Bs & 다 충 & & & & $=$ & \multicolumn{8}{|c|}{$\mathrm{B}$ 가 A보다 중요 } & B \\
\hline 수익성 & (9) & (8) & (7) & (6) & (5) & (4) & (3) & (2) & (1) & (2) & (3) & (4) & (5) & (6) & (7) & (8) & (9) & $\begin{array}{l}\text { 피투자 } \\
\text { 기업 } \\
\text { 만족도 }\end{array}$ \\
\hline
\end{tabular}

\begin{tabular}{|c|c|c|c|c|c|c|c|c|c|c|c|c|c|c|c|c|c|c|}
\hline & 그ㄱㅜㅜㅇㅇㅣ & & $\begin{array}{l}\text { 매웅 } \\
\text { 중요 }\end{array}$ & & 중요 & & 얒궁간 & & 동등 & & 약강간 & & 중요 & & 매중우 & & 그ㄱㅜㅜㅇㅇㅛ & \\
\hline A & & & $A^{\top}$ & & 다 중 & & & & $=$ & \multicolumn{3}{|r|}{$B^{7}$} & \multicolumn{5}{|c|}{$\mathrm{A}$ 보다 중요 } & B \\
\hline 수익성 & (9) & (8) & (7) & (6) & (5) & (4) & (3) & (2) & (1) & (2) & (3) & (4) & (5) & (6) & (7) & (8) & (9) & 해외매출 \\
\hline
\end{tabular}

\begin{tabular}{|c|c|c|c|c|c|c|c|c|c|c|c|c|c|c|c|c|c|c|}
\hline & 긍훙요 & & 매중우 & & 중요 & & 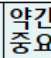 & & 동등 & & \begin{tabular}{|l} 
얒강난 \\
\end{tabular} & & 중요 & & 매중우 & & 극훙요 & \\
\hline A & & & $A^{7}$ & & 다 충 & 요 & & & $=$ & & & $B^{7}$ & A보 & 다 중 & 요 & & & B \\
\hline $\begin{array}{l}\text { 피투장 } \\
\text { 긴첫도 }\end{array}$ & (9) & (8) & (7) & (6) & (5) & (4) & (3) & (2) & (1) & (2) & (3) & (4) & (5) & (6) & (7) & (8) & (9) & 해외매출 \\
\hline
\end{tabular}

5. 결과[0utcome]을 위한 평가항목 중 어느 항목이 얼마나 더 중요하다고 생각하십니까?

- 고용증가: 투자를 통해 나타난 고용의 증가 정도

- 산업육성기여: 해당 산업의 매출액, 수출액 증대 등 해당 분야의 산업발전 기여 정도

- IP(OSMU)수익 창출: 투자한 프로젝트에서 창출한 IP수익 정도(웹툰의 영화화 등)

- 투자기업성장성: 투자한 기업의 매출액, 기업가치 등의 성장 정도

- 생존율: 투자한 기업들의 생존율 정도

- 산업분산도: 투자포트폴리오의 산업분산 정도

(다양한 분야, 장르, 규모 등 다양하게 투자될 경우 높은 점수)

- 국가브랜드 제고: 투자한 기업의 성과를 통한 한류 및 국가 브랜드 이미지 제고 정도

\begin{tabular}{|c|c|c|c|c|c|c|c|c|c|c|c|c|c|c|c|c|c|c|}
\hline & 긍훙요 & & 매숭우 & & 중요 & & 얒강아 & & 동등 & & 얒강앙 & & 중요 & & 매숭우 & & 궁훙요 & \\
\hline A & & & $A^{7}$ & & 다 출 & 요 & & & $=$ & & & BD & A보 & 다 중 & 됴됴 & & & B \\
\hline 고용증가 & (9) & (8) & (7) & (6) & (5) & (4) & (3) & (2) & (1) & (2) & (3) & (4) & (5) & (6) & (7) & (8) & (9) & 산업육성 \\
\hline
\end{tabular}




\begin{tabular}{|c|c|c|c|c|c|c|c|c|c|c|c|c|c|c|c|c|c|c|}
\hline & 극훙이 & & 매중우 & & 중요 & & 얒궁강 & & 동등 & & 얒궁강 & & 중요 & & \begin{tabular}{|l} 
매주ㅇㅜㅜ \\
웅
\end{tabular} & & 극훙이 & \\
\hline A & & & $A^{7}$ & B토 & 다 중 & & & & $=$ & & & $B$ 기 & A보 & 다 중 & 8 & & & B \\
\hline 고용증가 & (9) & (8) & (7) & (6) & (5) & (4) & (3) & (2) & (1) & (2) & (3) & (4) & (5) & (6) & (7) & (8) & (9) & $\begin{array}{l}\text { IP(OSMU) } \\
\text { 수익창출 }\end{array}$ \\
\hline
\end{tabular}

\begin{tabular}{|c|c|c|c|c|c|c|c|c|c|c|c|c|c|c|c|c|c|c|}
\hline & 긍훙요 & & 맹웅요 & & 중요 & & 양강요 & & 동등 & & 야ㅈㅜㅜ강 & & 중요 & & 매중웅 & & \begin{tabular}{|l|} 
긍힝요 \\
\end{tabular} & \\
\hline A & & & $A^{7}$ & $B$ E & 다 출 & & & & $=$ & & & BD & A보 & 다 & 요 & & & B \\
\hline 고용증가 & (9) & (8) & (7) & (6) & (5) & (4) & (3) & (2) & (1) & (2) & (3) & (4) & (5) & (6) & (7) & (8) & (9) & $\begin{array}{l}\text { 투작기ㅇㅓㅓ } \\
\text { 상성 }\end{array}$ \\
\hline
\end{tabular}

\begin{tabular}{|c|c|c|c|c|c|c|c|c|c|c|c|c|c|c|c|c|c|c|}
\hline & 극훙요 & & 매중웅 & & 중요 & & 얒강강 & & 동등 & & 얒강강 & & 중요 & & 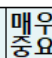 & & 극힝요 & \\
\hline A & & & $A^{\top}$ & & 다 츨 & & & & $=$ & & & $B 7$ & A보 & 다 줄 & 5 & & & B \\
\hline 고용증가 & (9) & (8) & (7) & (6) & (5) & (4) & (3) & (2) & (1) & (2) & (3) & (4) & (5) & (6) & (7) & (8) & (9) & 생존율 \\
\hline
\end{tabular}

\begin{tabular}{|c|c|c|c|c|c|c|c|c|c|c|c|c|c|c|c|c|c|c|}
\hline & 극훙이 & & 매중웅 & & 중요 & & 얒궁간 & & 동등 & & 야ㅈㅜㅜㅇ가뇨 & & 중요 & & 매중ㅇ & & 극훙효 & \\
\hline A & & & $A^{7}$ & B보 & 다 출 & & & & $=$ & & & B기 & A보 & 다 중 & 5 & & & B \\
\hline 고용증가 & (9) & (8) & (7) & (6) & (5) & (4) & (3) & (2) & (1) & (2) & (3) & (4) & (5) & (6) & (7) & (8) & (9) & 산선단도 \\
\hline
\end{tabular}

\begin{tabular}{|c|c|c|c|c|c|c|c|c|c|c|c|c|c|c|c|c|c|c|}
\hline & 긍훙요 & & 맹웅요 & & 중요 & & 얒궁간 & & 동등 & & 야ㅈㅜㅜ강 & & 중요 & & 매수웅 & & 극훙요 & \\
\hline A & & & $A^{2}$ & B보 & 다 줄 & 요 & & & $=$ & & & B7 & A보 & 다 중 & 됴 & & & B \\
\hline 고용증가 & (9) & (8) & (7) & (6) & (5) & (4) & (3) & (2) & (1) & (2) & (3) & (4) & (5) & (6) & (7) & (8) & (9) & $\begin{array}{l}\text { 브ㄷㅏㅐㄷㅏ } \\
\text { 제고 }\end{array}$ \\
\hline
\end{tabular}

\begin{tabular}{|c|c|c|c|c|c|c|c|c|c|c|c|c|c|c|c|c|c|c|}
\hline & \begin{tabular}{|l|} 
ㄱㅡㅜ힝요 \\
\end{tabular} & & $\begin{array}{l}\text { 맹웅ㅇ } \\
\end{array}$ & & 중요 & & 얒강요 & & 동등 & & 얒궁강 & & 중요 & & 매중우 & & \begin{tabular}{|l|} 
긍힝요 \\
\end{tabular} & \\
\hline A & & & $A^{7}$ & B보 & 다 중 & 8 & & & $=$ & & & $B 7$ & $\mathrm{~A}$ 보 & 다 중 & 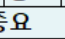 & & & B \\
\hline $\begin{array}{l}\text { 산업육성 } \\
\text { 기여 }\end{array}$ & (9) & (8) & (7) & (6) & (5) & (4) & (3) & (2) & (1) & (2) & (3) & (4) & (5) & (6) & (7) & (8) & (9) & \begin{tabular}{|l|} 
IP(OSMUY \\
수익창출
\end{tabular} \\
\hline
\end{tabular}

\begin{tabular}{|c|c|c|c|c|c|c|c|c|c|c|c|c|c|c|c|c|c|c|}
\hline & 긍훙요 & & 매ㅇㅜㅜㅇㅇ & & 중요 & & 양강요 & & 동등 & & 야ㅈㅜㅜ강 & & 중요 & & 매중웅 & & 극훙요 & \\
\hline A & & & $A^{\top}$ & & 다 출 & 8 & & & $=$ & & & B기 & A보 & 다 중 & 5요 & & & B \\
\hline $\begin{array}{c}\text { 산업육성 } \\
\text { 기여 }\end{array}$ & (9) & (8) & (7) & (6) & (5) & (4) & (3) & (2) & (1) & (2) & (3) & (4) & (5) & (6) & (7) & (8) & (9) & $\begin{array}{l}\text { 투작ㄱㅇㅓㅓㅂㅓ } \\
\text { 성장성 }\end{array}$ \\
\hline
\end{tabular}

\begin{tabular}{|c|c|c|c|c|c|c|c|c|c|c|c|c|c|c|c|c|c|c|}
\hline & 극훙요 & & 매ㅈㅜㅜㅇㅇ & & 중요 & & 얒강요 & & 동등 & & 얒궁요 & & 중요 & & 매중우 & & 극훙요 & \\
\hline A & & & $A^{\lambda}$ & & 다 중 & 요 & & & $=$ & & & BD & A보 & 다늘 & 8 & & & B \\
\hline \begin{tabular}{|c|} 
산업육성 \\
기여
\end{tabular} & (9) & (8) & (7) & (6) & (5) & (4) & (3) & (2) & (1) & (2) & (3) & (4) & (5) & (6) & (7) & (8) & (9) & 생존율 \\
\hline
\end{tabular}

\begin{tabular}{|c|c|c|c|c|c|c|c|c|c|c|c|c|c|c|c|c|c|c|}
\hline & \begin{tabular}{|l|} 
궁힝요 \\
\end{tabular} & & 매중우 & & 중요 & & 야ㅈㅜㅜㅇ강 & & 동등 & & 얒궁강 & & 중요 & & 매중우 & & \begin{tabular}{|l} 
긎히이 \\
요요
\end{tabular} & \\
\hline A & & & A & $B$ 트 & 다 충 & & & & $=$ & \multicolumn{8}{|c|}{ B가 A보다 중요 } & B \\
\hline $\begin{array}{c}\text { 산업육성 } \\
\text { 기여 }\end{array}$ & (9) & (8) & (7) & (6) & (5) & (4) & (3) & (2) & (1) & (2) & (3) & (4) & (5) & (6) & (7) & (8) & (9) & $\begin{array}{l}\text { 산업 } \\
\text { 반도 }\end{array}$ \\
\hline
\end{tabular}

\begin{tabular}{|c|c|c|c|c|c|c|c|c|c|c|c|c|c|c|c|c|c|c|}
\hline & \begin{tabular}{|l} 
긍힝요 \\
\end{tabular} & & 맹웅요 & & 중요 & & 양강안 & & 동등 & & 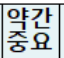 & & 중요 & & 매숭웅 & & \begin{tabular}{|c|} 
궁힝 \\
\end{tabular} & \\
\hline A & & & $A^{7}$ & B보 & 다 중 & 요 & & & $=$ & & & $B 7$ & $\mathrm{~A}$ 보 & 다 중 & 5요 & & & B \\
\hline $\begin{array}{c}\text { 산업육성 } \\
\text { 기여 }\end{array}$ & (9) & (8) & (7) & (6) & (5) & (4) & (3) & (2) & (1) & (2) & (3) & (4) & (5) & (6) & (7) & (8) & (9) & $\begin{array}{l}\text { 국감 } \\
\text { 른드 }\end{array}$ \\
\hline
\end{tabular}




\begin{tabular}{|c|c|c|c|c|c|c|c|c|c|c|c|c|c|c|c|c|c|c|}
\hline & 긍힝요 & & 매중우 & & 중요 & & 얒강요 & & 동등 & & 얒강난 & & 중요 & & 매중우 & & ㄱㅡㅜ힝요 & \\
\hline A & & & $A^{\top}$ & & 다 출 & & & & $=$ & & & & A보 & 다를 & & & & B \\
\hline $\begin{array}{l}\text { IP(OSMUN } \\
\text { 수익창출 }\end{array}$ & (9) & (8) & (7) & (6) & (5) & (4) & (3) & (2) & (1) & (2) & (3) & (4) & (5) & (6) & (7) & (8) & (9) & 두성강성 \\
\hline
\end{tabular}

\begin{tabular}{|c|c|c|c|c|c|c|c|c|c|c|c|c|c|c|c|c|c|c|}
\hline & 긍훙요 & & \begin{tabular}{|l|} 
맹우요 \\
\end{tabular} & & 중요 & & 얒강요 & & 동등 & & 얒강요 & & 중요 & & 맹웅요 & & 긍힝요 & \\
\hline A & & & $A^{7}$ & & 다 중 & 8 & & & $=$ & & & & $\mathrm{A}$ 보 & 다 & S8 & & & B \\
\hline 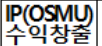 & (9) & (8) & (7) & (6) & (5) & (4) & (3) & (2) & (1) & (2) & (3) & (4) & (5) & (6) & (2) & (8) & (9) & 생존율 \\
\hline
\end{tabular}

\begin{tabular}{|c|c|c|c|c|c|c|c|c|c|c|c|c|c|c|c|c|c|c|}
\hline & 긍훙요 & & 맹웅요 & & 중요 & & 챵궁요 & & 동등 & & 얒궁간 & & 중요 & & 매ㅈㅜㅜㅇㅜ & & 긍훙요 & \\
\hline A & & & $A^{7}$ & B토 & 다 중 & 8 & & & $=$ & & & B기 & & 다 & 要 & & & B \\
\hline |P(OSMU & (9) & (8) & (7) & (6) & (5) & (4) & (3) & (2) & (1) & (2) & (3) & (4) & (5) & (6) & (7) & (8) & (9) & $\begin{array}{l}\text { 산업 } \\
\text { 분도노․ }\end{array}$ \\
\hline
\end{tabular}

\begin{tabular}{|c|c|c|c|c|c|c|c|c|c|c|c|c|c|c|c|c|c|c|}
\hline & 긋힝요 & & 매ㅈㅜㅜㅇㅇㅛ & & 중요 & & 얒강강 & & 동등 & & 야ㅈㅜㅜ앙ㅇ & & 중요 & & 매ㅈㅜㅜㅇㅇㅇ & & 극훙요 & \\
\hline A & & & $A^{7}$ & $B$ 보 & 다 중 & 8 & & & $=$ & & & & A보 & 다 & 요 & & & B \\
\hline $\begin{array}{l}\text { IPOOSMU } \\
\text { 수익창출 }\end{array}$ & (9) & (8) & (7) & (6) & (5) & (4) & (3) & (2) & (1) & (2) & (3) & (4) & (5) & (6) & (7) & (8) & (9) & 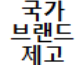 \\
\hline
\end{tabular}

\begin{tabular}{|c|c|c|c|c|c|c|c|c|c|c|c|c|c|c|c|c|c|c|}
\hline & 긍훙요 & & 매ㅈㅜㅜㅇㅜ & & 중요 & & 얒강앙 & & 동등 & & 얒강강 & & 중요 & & 매중우 & & 긍힝요 & \\
\hline A & & & & B보 & 다 중 & 요 & & & $=$ & & & B기 & A보 & 다 중 & 且 & & & B \\
\hline 투장기ㅇㅓㅓ엉 & (9) & (8) & (7) & (6) & (5) & (4) & (3) & (2) & (1) & (2) & (3) & (4) & (5) & (6) & (7) & (8) & (9) & 생존율 \\
\hline
\end{tabular}

\begin{tabular}{|c|c|c|c|c|c|c|c|c|c|c|c|c|c|c|c|c|c|c|}
\hline & 긋훙요 & & 맹웅요 & & 중요 & & 쟞강요 & & 동등 & & 챶궁요 & & 중요 & & 매중우 & & 극훙요 & \\
\hline A & & & $A^{7}$ & B토 & 다 중 & 8 & & & $=$ & & & Bᄀ & A보 & 다 중 & 监 & & & B \\
\hline 투장징엉성 & (9) & (8) & (7) & (6) & (5) & (4) & (3) & (2) & (1) & (2) & (3) & (4) & (5) & (6) & (7) & (8) & (9) & 산언선도 \\
\hline
\end{tabular}

\begin{tabular}{|c|c|c|c|c|c|c|c|c|c|c|c|c|c|c|c|c|c|c|}
\hline & 긍훙요 & & 맹웅요 & & 중요 & & 얒궁강 & & 동등 & & 얒강강 & & 중요 & & 매숭우 & & 극훙요 & \\
\hline A & & & $A^{7}$ & B보 & 다 중 & 요 & & & $=$ & & & B기 & A보 & 다 중 & 요 & & & B \\
\hline 툿정강엉엉 & (9) & (8) & (7) & (6) & (5) & (4) & (3) & (2) & (1) & (2) & (3) & (4) & (5) & (6) & (7) & (8) & (9) & 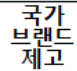 \\
\hline
\end{tabular}

\begin{tabular}{|c|c|c|c|c|c|c|c|c|c|c|c|c|c|c|c|c|c|c|}
\hline & 극훙요 & & 맹웅요 & & 중요 & & 얒궁간 & & 동등 & & 야ㅈㅜㅜㅇ강 & & 중요 & & 매중우 & & 극힝요 & \\
\hline$A$ & & & & B보 & 다 줄 & 8 & & & $=$ & & & $B$ B & A보 & 다 & 要 & & & B \\
\hline 생존율 & (9) & (8) & (7) & (6) & (5) & (4) & (3) & (2) & (1) & (2) & (3) & (4) & (5) & (6) & (7) & (8) & (9) & 산언돈ㄷ \\
\hline
\end{tabular}

\begin{tabular}{|c|c|c|c|c|c|c|c|c|c|c|c|c|c|c|c|c|c|c|}
\hline & 긋훙요 & & 맹웅요 & & 중요 & & 얒강앙 & & 동등 & & 얒강강 & & 중요 & & 매ㅈㅜㅜㅇㅜ & & 극힝요 & \\
\hline$A$ & & & $A^{\top}$ & B보 & 다 중 & 요 & & & $=$ & & & BD & A보 & 다 중 & 严 & & & B \\
\hline 생존율 & (9) & (8) & (7) & (6) & (5) & (4) & (3) & (2) & (1) & (2) & (3) & (4) & (5) & (6) & (7) & () & (9) & $\begin{array}{l}\text { 국각 } \\
\text { 븐드도 }\end{array}$ \\
\hline
\end{tabular}

\begin{tabular}{|c|c|c|c|c|c|c|c|c|c|c|c|c|c|c|c|c|c|c|}
\hline & 극훙요 & & 매ㅈㅜㅜㅇㅇ & & 중요 & & 얒강강 & & 동등 & & 얒강용 & & 중요 & & 매ㅈㅜㅜㅇㅇㅜ & & 극훙요 & \\
\hline A & & & $A^{7}$ & B보 & 다 중 & 요 & & & $=$ & & & Bᄀ & A보 & 다 를 & fi & & & B \\
\hline $\begin{array}{l}\text { 산언언도 } \\
\text { S }\end{array}$ & (9) & (8) & (7) & (6) & (5) & (4) & (3) & (2) & (1) & (2) & (3) & (4) & (5) & (6) & (7) & (8) & (9) & $\begin{array}{l}\text { 국각 } \\
\text { 블ㄷㄷ }\end{array}$ \\
\hline
\end{tabular}




\section{집필내역}

연구책임

박찬욱 한국문화관광연구원 연구위원: 제 1 장, 제4장, 제 5 장, 연구총괄

양지훈 한국문화관광연구원 연구원: 제 2 장, 제 3 장, 제4장, 연구총괄

\section{공동연구}

이관영 한국문화관광연구원 위촉책임연구원: 제3장 1절, 제4장 3절

설원식 숙명여대 경영학 교수: 제3장 2절, 제4장 2절, 3절

이준호 호서대 경영학 교수: 제3장 2절, 제4장 2절, 3절

이태호 한국자산운용연구원 원장: 제3장 2절, 제4장 2절, 3절

\section{모태펀드 문화계정 성과지표 개발 연구}

발행인 김대관

발행처 한국문화관광연구원

서울시 강서구 금낭화로 154

전화 02-2669-9800 팩스 02-2669-9880

http://www.kcti.re.kr

인쇄일 2020년 10월 13일

발행일 2020년 10월 13일

인쇄인 (사)한국장애인이워크협회 일자리사업장

I S B N 978-89-6035-823-293300

DOI https://doi.org/10.16937/kcti.rep.2020.e5 


\section{A Study on the Development of Performance Indicators for Cultural Account of Fund of Funds}

